\title{
Constrictional deformation of the Koster dyke swarm in a ductile sinistral shear zone, Koster islands, SW Sweden
}

\author{
BJøRN HAGESKOV
}

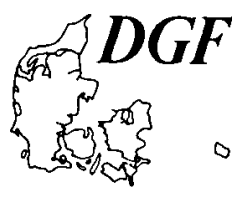

Hageskov, B.: Constrictional deformation of the Koster dyke swarm in a ductile sinistral shear zone, Koster islands, SW Sweden. Bull. geol. Soc. Denmark vol. 34, pp. 151-197, Copenhagen, December, 19th, 1985. https://doi.org/10.37570/bgsd-1985-34-14

The Koster-Kattsund dyke swarm is an important element in the Sveconorwegian province of the Baltic shield. Dyke intrusion took place in the period 1225-1015 Ma. Throughout most of the swarm the dykes are strongly deformed and thoroughly recrystallised into lineated amphibolites as a result of a Sveconorwegian tectonic event about $1000 \mathrm{Ma}$ ago. However, in the Koster archipelago fresh dolerites can be followed northwards in to partially recrystallised metadolerites and finally into the totally recrystallised, lineated amphibolites that characterise the swarm.

In the Koster archipelago intense dyking resulted in the formation of a multilayered rock sandwich consisting of alternating layers of gneiss and dolerite. The sandwich trends NNE and dips $67^{\circ} \mathrm{W}$. The dolerite dykes have a mean thickness of $2.2 \mathrm{~m}$ and they occupy $15-20 \%$ of the total rock mass. To the northeast the sandwich becomes progressively deformed and ultimately shows very high strain of pure constrictional type. The deformation took place in a steep NW-SE-trending ductile shear zone. During the initial shear zone deformation $\left(D_{4 a}\right)$ the sandwich underwent anticlockwise bending and the large Kyrkosund synform was formed. The fold plunges $303 / 66$ and has a NW-SE-trending axial surface. The bending took place by means of flexural-slipfolding in which the layer-parallel shearing waslocated in incompetent dyke layers. Increasing shearing and recrystallisation in a NW-SE-trending belt crossing the northern limb of the Kyrkosund synform resulted in a softening of this belt. The succeeding event $\left(D_{4 b}\right)$ was localised in this initial soft belt, and involved sinistral simple shear combined with pure shear resulting in horizontal widening and vertical shortening of the belt. This composite deformation formed the pure constrictional fabric now seen in the rocks. The strong $D_{4 b}$ stretching was followed by the formation of trains of asymmetric folds $\left(D_{4 c}\right.$ and $\left.d_{4 d}\right)$.

It is demonstrated that volume changes in the dyke rock during deformation were negligible, and that no competence contrast between gneiss and dyke rock existed during the $D_{4 b}$ stretching. The finite constrictional strain ellipsoid has the dimensions $X=7.07, Y=Z=0.18$. The composite simple/pure shear deformation that presumably caused the constriction has a simple shear component $\gamma=10.9$, corresponding to an angular shear of $84.7^{\circ}$. The pure shear deformation resulted in a 3.4 times horizontal widening of the initial soft belt. The horizontal sinistral displacement within the shear zone was at least $35 \mathrm{~km}$.

Björn Hageskov, Institut for almen geologi, Østervold Gade 10, DK-1350, Copenhagen. January3rd, 1985.

\section{Introduction}

The southwestern part of the Baltic shield underwent in the period $1200-850$ Ma ago the Sveconorwegian orogeny, which is the Scandinavian counterpart of the Grenville orogeny of North America. The Sveconorwegian orogenic province (Fig. 1) has been subdivided by Berthelsen (1980) into a western subprovince in which huge amounts of Sveconorwegian granitoids were added to the present crustal section (Pedersen et al. 1978, Falkum \& Petersen 1980, Hageskov 1980), and an eastern subprovince in which the orogenesis has the character of a tectonic-metamorphic reworking of pre-Sveconorwegian rocks (see a.o. Berthelsen 1980, Daly et al. 1983, Ha- geskov 1980, Morthorst et al. 1983, Samuelsson 1980 , Starmer 1972, 1977). The two subprovinces are separated by the Kriastiansand-Bagn* shear zone (Hageskov 1980). In the eastern subprovince much of the strain resulting from the reworking was localised in $\mathrm{N}-\mathrm{S}$ trending shear zones, some of which are believed to be deep thrusts connected to crustal peeling of large segments of the pre-Sveconorwegian crust (Berthelsen 1978, 1980). The large slabs have generally been thrust from the west as a reaction to the overall E-W shortening of the subprovince.

\footnotetext{
* In the paper (Hageskov 1980) where the name "KristiansandBagn shear zone" was introduced, the name of the village Bagn was incorrectly spelt Bang.
} 


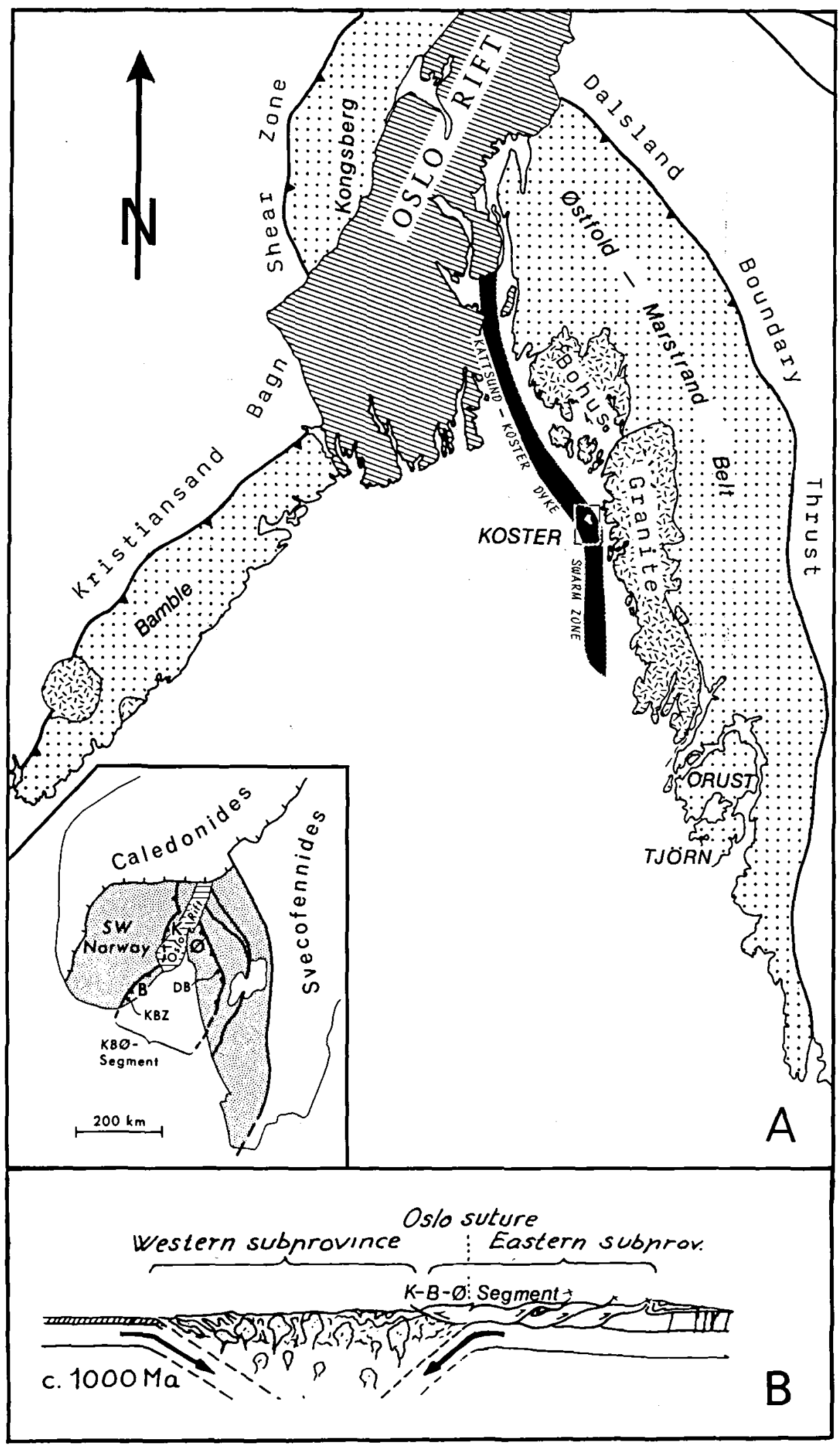

Fig. 1. A) The Kattsund-Koster dyke swarm zone in the Kongsberg-Bamble- $\emptyset$ stfold segment (K-B- $\emptyset$ segment) of the Sveconorwegian province. B) The profile is a plate-tectonic model of the Sveconorwegian province (from Berthelsen (1980)). 
One of the most important segments of the Sveconorwegian province is the KongsbergBamble- $\emptyset$ stfold segment (K-B- $\varnothing$ segment, Hageskov 1980) forming the westernmost segment of the eastern subprovince. Considerable interest is attached to this segment because of its tectonic position, the Sveconorwegian reworking tectonics that characterise the segment and the relics within it of a pre- or early Sveconorwegian spreading zone (the Kattsund-Koster dyke swarm zone). The segment is believed to have been thrust both to the west and to the east, to the west on the Kristiansand-Bagn shear zone (Hageskov 1980) and to the east on the Dalsland boundary thrust (Berthelsen 1978). The unusual westwards direction of thrusting on the Kristiansand-Bagn shear zone was explained by Berthelsen $(1980$, p. 11) in a plate tectonic model as counterthrusting "onto a western plate while post-collisional crustal peeling and slicing operated to the east during continued subduction below the western plate". In this model (Fig. 1B) the subduction zone (the Oslo suture) was placed below the central part of the K-B- $\varnothing$ segment.

Structural investigations in the central part of the K-B- $\emptyset$ segment are hampered by the fact that this part of the segment is largely hidden by the sea and by Permian rocks of the Oslo Rift. However, in the exposures in the Oslofjorden region and along the coast of Bohus Län, W Sweden, it is possible to demonstrate two events of major importance to the understanding of the Sveconorwegides, but these events are not easily related to a subduction beneath the K-B- $\varnothing$ segment.

The first of these events is the formation of a spreading zone, evidence of which is seen in the Kattsund-Koster dyke swarm zone running along the coast of Bohus Län and into Oslofjorden, where it disappears in the Oslo Rift (Hageskov 1984). The dyke swarm zone includes the Kattsund dykes of Oslofjorden (Hageskov 1978) and the Koster dykes of Bohus Län (DeGeer 1899, Asklund 1950). Both swarms are very dense and consist of strongly evolved tholeiites derived from $\mathrm{Ol}$ tholeiitic parent magmas with affinity to present MORB (Hageskov in prep.). In the at least $8 \mathrm{~km}$ wide and intense dyke swarm the crust has expanded $15-30 \%$. Most of the dykes have been altered to strongly deformed amphibolites. The exact age of the dyking is not known, but ac- cording to Hageskov \& Pedersen (1981) the dykes were most likely injected during the period 1225-1015 Ma ago. Rb-Sr age determination by Daly et al. (1983) on dykes possibly related to the Koster - and the Kattsund dykes suggest a metamorphic age of $1090 \mathrm{Ma}$ as a minimum for the dyking.

The second event is an episode of strong ductile deformation under amphibolite facies conditions, during which the Kattsund-Koster dyke swarm zone became involved in a steep NW-SE to N-S trending ductile shear zone with constrictional deformation. A very high component of simple shear has resulted in a subhorizontal sinistral displacement of more than $35 \mathrm{~km}$. In the Oslofjorden region, just east of the sinistral shear zone, another ductile shear zone occurs (the eastern part of the Fjord zone, Hageskov 1980), in which a N-S trending and moderately westwardsdipping planar fabric with a strong component of westwards-plunging stretching was imposed on older structures. This zone is regarded as a ductile thrust zone with thrusting from the west. The age of this zone is suggested to be $1015 \mathrm{Ma}$ (Hageskov \& Pedersen 1981). The age relations between the sinistral shear zone and the ductile thrust zone are uncertain, but the latter is believed to be slightly older.

The coastal position of the Kattsund-Koster dyke swarm zone and the sinistral shear zone(s) restrict the investigations of the dykes and the superimposed deformation to a few minor areas of which the Sandbukta-Mølen inlier in the Oslo graben (Hageskov 1978) and the Koster archipelago are the most important.

This paper is a detailed structural study of the dense Koster dyke swarm and the evolution of a unique sinistral ductile shear zone, in which the rock mass has undergone a strong and almost purely constrictional deformation under conditions of amphibolite facies metamorphism. The well exposed Koster archipelago offers excellent conditions for such studies. The NW-SE-trending shear zone occurs in the northeast part of the archipelago, where it is superimposed on a multilayered rock sandwich consisting of alternating layers of undeformed Koster dykes and already deformed gneisses. This sandwich (Fig. 2), which is undeformed in the southwest part of the archipelago, becomes bent in the marginal part of the shear zone, while it is strongly stretched in a hori- 


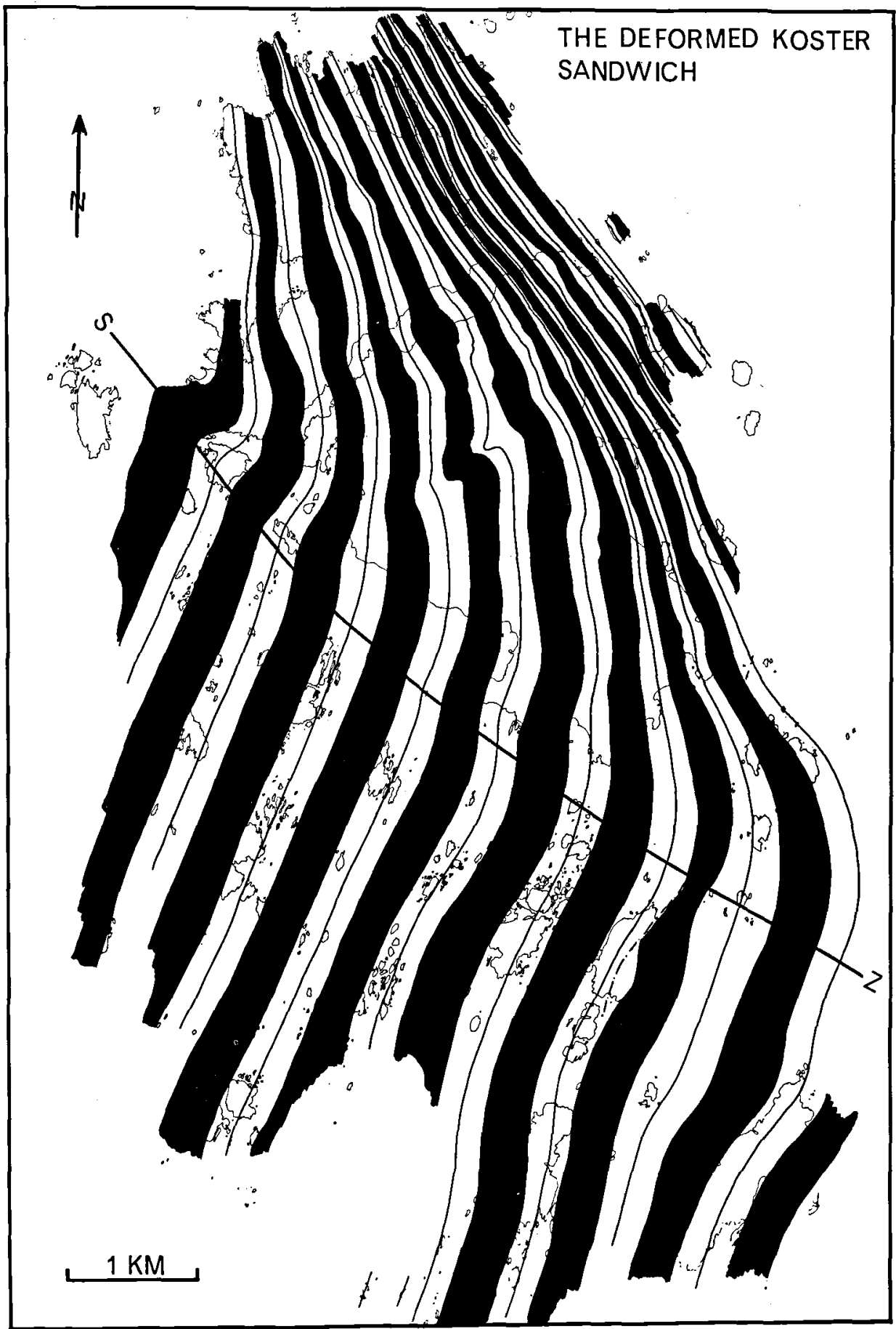

Fig. 2. The deformed Koster sandwich. S-Z is the SW boundary of the Koster shear zone.

zontal NW-SE direction in the more centrally positioned part of the shear zone. That part is called "the high strain belt" (see Fig. 3).
The pattern of recrystallisation in the shear zone (Fig. 3) was established from the state of the dyke rocks. Sector I covers the area where the 


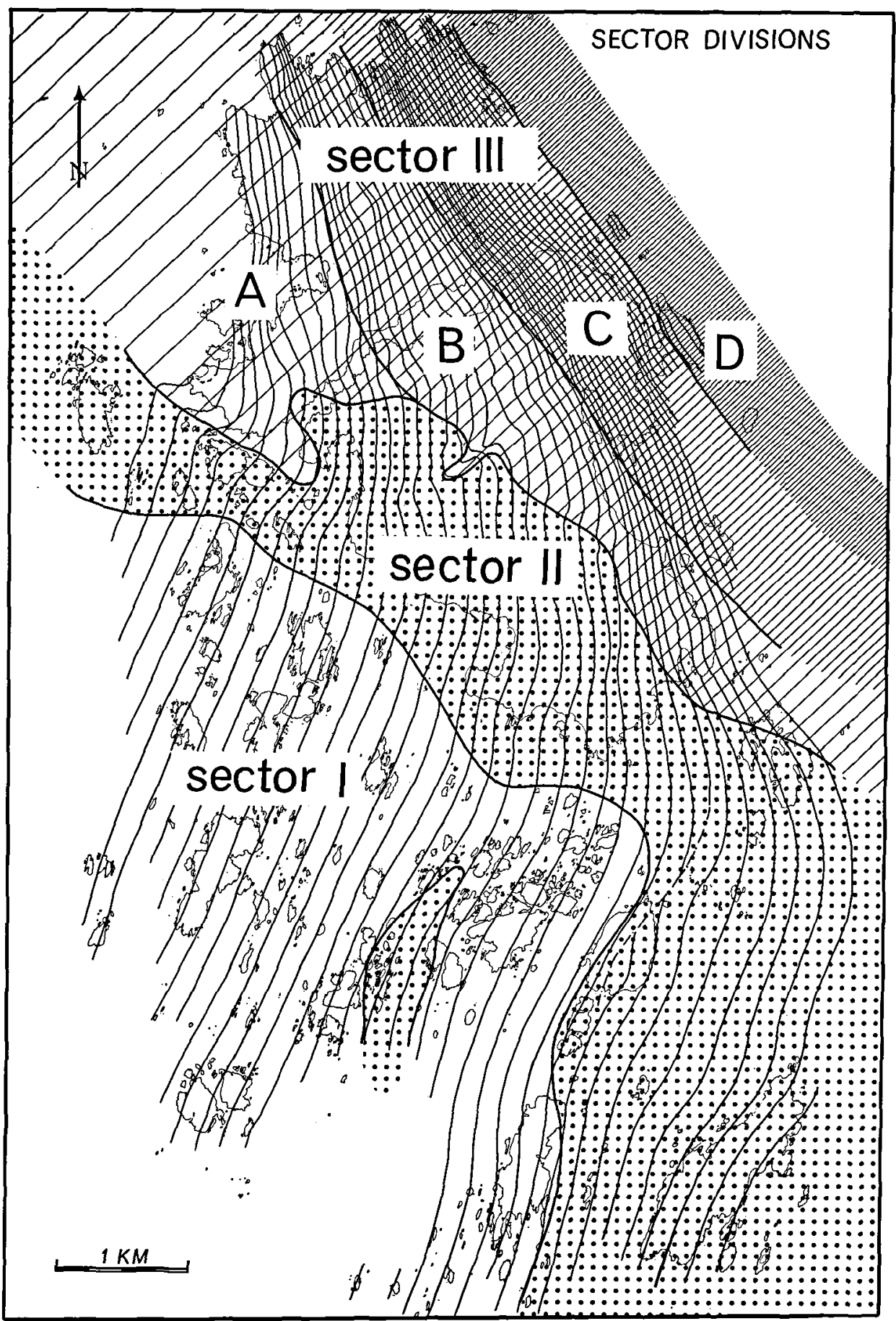

Fig. 3. Sector division of the Koster archipelago. Subsector IIIB, C and D form a high strain belt. The map also shows the trends of the dykes.

rock sandwich is undeformed and the dykes almost fresh igneous dolerites. Sector II covers mostly the area in the marginal part of the shear zone, where the dykes are partly recrystallised metadolerites. Sector III is the sector of strongly deformed rocks, the dyke rock having been here 
totally recrystallised to lineated amphibolite. The subsectors IIIB, IIIC and IIID make up the high strain belt.

The unique structural situation in the shear zone has allowed strain calculations, modelling of the deformation mechanism and a reconstruction of the pre-shear zone structures within the area now occupied by the shear zone.

\section{Previous work}

The small Koster archipelago $(11 \mathrm{~km} \times 6.5 \mathrm{~km})$ in the extreme west of Sweden has attracted the attention of geologists mainly because of the Koster dyke swarm, and it is mentioned in almost all summaries of the Precambrian of Sweden (e.g. Magnusson 1963, Geijer 1963, Lundegårdh 1963, Lundqvist 1979). However, knowledge of the Koster dykes and the superimposed deformation goes back to De Geer $(1899,1902)$ and Asklund (1950).

DeGeer recognised already in 1899 that the dense Koster dyke swarm as well as the "granite" layers between the dykes become strongly deformed in a N-S-trending zone in the eastern part of the archipelago, where the rocks becomes amphibolite and gneiss respectively. According to DeGeer, the initial joint system into which the dykes were injected was developed as a result of the same stress situation as that which later resulted in the deformation of the 'granite' and dyke layers. This deformation was related to a young Precambrian orogenesis ('Algonkian').

Asklund (1950) provided the first detailed description (including a map) of the dykes and their recrystallisation. He believed that the Koster diabases form 'a dike system extending from the Oslo firth of south-eastern Norway, along the northern part of the west coast of Sweden to the skerries in the vincinity of Gothenburg' (op. cit. p. 58), and he recognised at least two generations of Koster dykes, of which the younger are the rarer. Besides the dykes, Asklund reported from $\mathrm{N}$ Koster small rounded or lens-shaped central vents and dykes, which swell into real stocks. With respect to the superimposed deformation and recrystallisation Asklund largely follows $\mathrm{De}_{-}-$ Geer, but he divided the strongly deformed area in the eastern part of the archipelago into three separate 'younger zones of schistozity' and repor- ted the occurrence of thrusts. Asklund (1950, p. 53) wrote furthermore: 'No doubt the schistozity and mylonitization of some of the older rocks are older than the intrusion-course of the diabases, but there are obvious reasons for the opinion that the course of the intrusion of the diabases was intimately combined with the particular younger tectonics of the coastal zone, whose most significant manifestation was the development of these zones of younger schistozity just described'. So Asklund agreed with DeGeer that there was an intimate connection between the dyke swarm formation and the superimposed deformation. However, neither of these two authors mention the regional bend of the dyke swarm (see Fig. 2).

Parts of Asklund's 'Koster diabase dike system" have recently been referred to as "Orust dykes' (Daily et al. 1983). These dykes cover a suite of deformed and metamorphosed dykes seen in Orust and Tjörn in the southern part of Bohus Län, and they are expected to be the probable equivalents to some of the Koster dykes and to the Kattsund dykes (Daly et al. op. cit.).

The injection of the widespread basic dykes seen along the coast of western Sweden has been used by some authors as a time marker for the older limit of the Sveconorwegian evolution (Samuelsson 1980, Daly et al. 1982).

\section{The Koster sandwich Chronological relations}

In order to study the Koster dykes and the younger shear zone deformation $\left(D_{4}\right.$; see Table $\left.I\right)$, the Koster dyke swarm as well as the gneiss terrain were mapped on a scale of 1:10.000. The mapping of the dyke swarm was supported by use of vertical areal photographs at the same scale.

A large number of rock units is present in the archipelago, but on the map Fig. 10 only the most conspicuous units are shown. These are briefly described in Table I. Table I shows furthermore the detailed stratigraphy.

Even though no rocks from the Koster archipelago have been dated yet, it is assumed that the crustal evolution of the area took place mainly in the period $1700-850 \mathrm{Ma}$ and that the majority of the rocks are pre-Sveconorwegian (>1200 Ma). This is in accordance with recent investigations within the Østfold-Marstrand belt of Daly et al. 


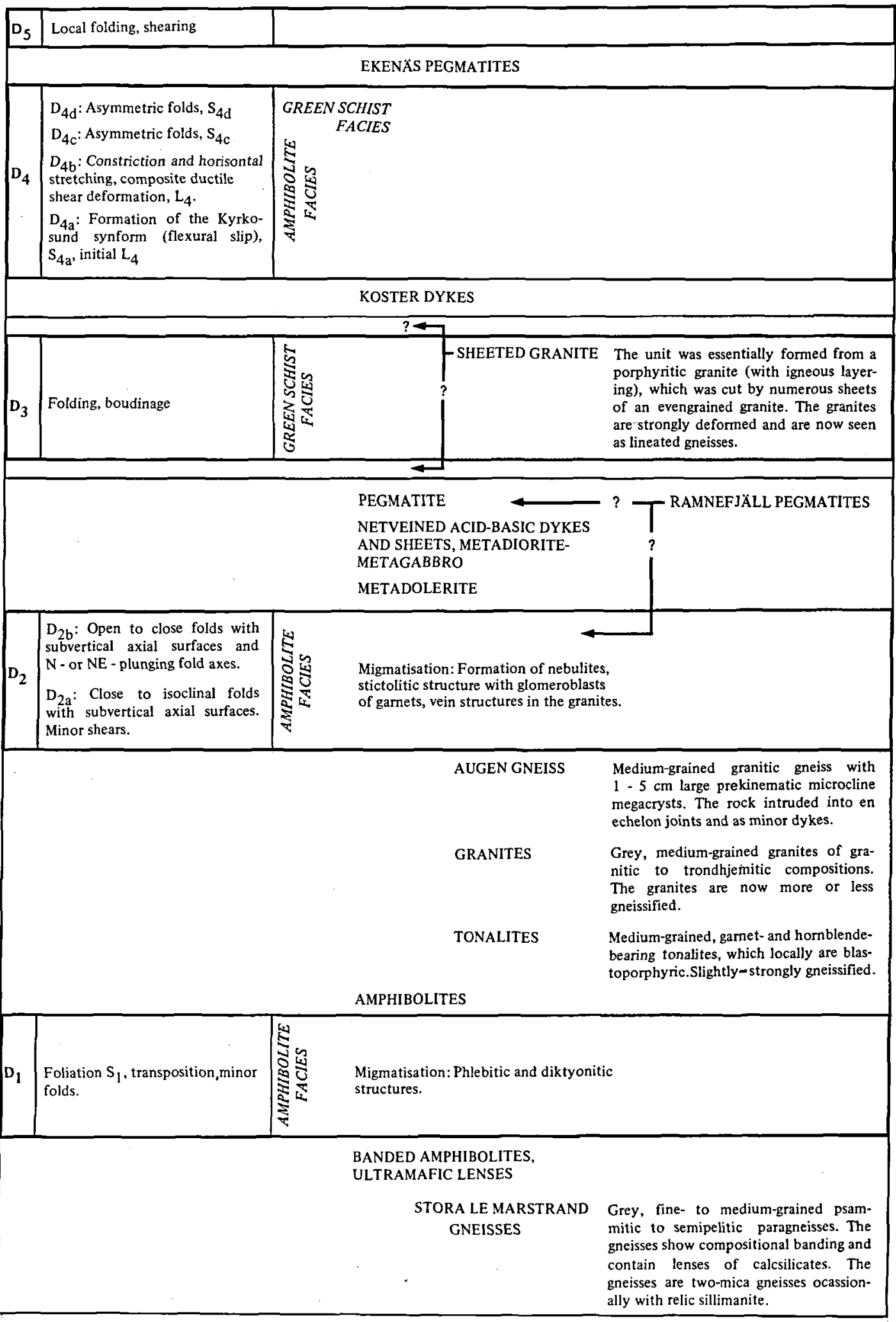


(1983) in the eastern part of the K-B- $\varnothing$ segment (Skiöld 1976, Daly et al. 1979, 1982, 1983, Welin \& Gorbatschev 1978, Park et al. 1979, Samuelsson \& Åhäll 1984, Hageskov 1978, 1980, Hageskov \& Pedersen 1981).

The polymetamorphic supracrustal Stora Le Marstrand formation (Larsson 1956, Lundegårdh 1958, Park et al, 1979, Hageskov \& Pedersen 1981 ) is not only the oldest, but it appears to be the fundamental component in the Koster archipelago as it is elsewhere in the $\emptyset$ stfold-Marstrand belt. The exact age of the deposition of the Stora Le Marstrand supracrustals is not known, but a $\mathrm{Rb}-\mathrm{Sr}$ whole rock age determination on one of the many intursive granitoids in the $\emptyset$ stfold-Marstrand belt has yielded an age of about $1650 \mathrm{Ma}$ (Welin \& Gorbatschev 1978). This gives a minimum age for the deposition of the formation, but according to Daly et al. (1983) the Stora Le Marstrand supracrustals had already undergone a phase of migmatisation at the time of the intrusion of the granitoids dated.

In the study of the $\mathrm{D}_{4}$ deformation (Table I) the Ekenäs pegmatites and the Ramnefjäll pegmatites are of special interest. The Ekenäs pegmatites mark the younger limit of the $\mathrm{D}_{4}$ deformation. These NE-SW trending pegmatites occur only in the $E$ and NE part of the archipelago (subsector IIIB, C, D), where they cut the highly deformed Koster dyke and gneiss layers at a large angle. Locally the pegmatites have been deformed by folding and shearing $\left(D_{5}\right)$, but their overall appearance is as undeformed dykes. Both Gavelin (1914) and Asklund (1950) overlooked the deformation of the Ekenäs pegmatites and related them to the nearby Bohus granite, a postkinematic Sveconorwegian granite batholith seen just east of the archipelago (Fig. 1). The Bohus granite has been dated by the Rb-Sr whole rock method at $891 \pm 34 \mathrm{Ma}$ (Skiöld 1976).

The Ramnefjäll pegmatites (Fig. 31) form a swarm of rather irregular pegmatite dykes followed by dykes of aplite and granite (rare). These pegmatites occur as densely spaced, slightly deformed NW-SE-trending dykes in the SW part of S Koster (sector II), and as strongly deformed dykes striking subparallel to the Koster dyke trend in the eastern part of $S$ and $N$ Koster (subsector IIIB, C, D). The Ramnefjäll pegmatites are important in the recognition of the Koster dykes in the most highly strained area of sec- tor III, because in N and S Koster the Koster dykes are the only amphibolities cutting the Ramnefjäll pegmatites.

\section{The sector division}

The sectors shown in Fig. 3 are based on the study of the degree of $\mathrm{D}_{4}$ deformation and metamorphism of the Koster dykes, as the dykes were deformed and recrystallised for the first time by $D_{4}$. The dykes have been especially useful in identifiying the initial, weak stages of $\mathrm{D}_{4}$ deformation because the dyke layers were more sensitive to deformation than the gneiss layers. The main sectors are also demonstrated by the regional magnetic susceptibility pattern of the dykes (Hageskov 1984).

Sector $\mathrm{I}$ is characterised by the absence of minor $\mathrm{D}_{4}$ structures and by very weak reactions within the dyke rock in response to the $\mathrm{D}_{4}$ tectono-metamorphic phase. The dyke rock itself is an almost fresh basaltic rock with a doleritic texture, and it always shows chilling against the host. Typically the dyke rock is formed of plagioclase $\left(\mathrm{An}_{70-35}\right)$, clinopyroxene, olivine $( \pm)$, biotite, hypersthene, hornblende, apatite, zircon, titanomagnetite, ilmenite and pyrrhotite $( \pm)$. About $5 \%$ of the dykes are porphyritic with phenocrysts of olivine or plagioclase or both. The phenocrysts rarely exceed $1 \mathrm{~cm}$ in size. The olivine is generally fresh with a double corona of hypersthene and hornblende against plagioclase. Even small phenocrysts og olivine and skeletal plagioclase may in the chilled margins be well preserved. Evidence of postcrystalline deformation is frequently seen as straining of the silicate grains. Here and there dykes show patchy recrystallisation and incipient amphibolitisation.

Passing into sector II very little evidence of $D_{4}$ is seen except in the dyke layers. Sector II covers the hinge zone of the major $\mathrm{D}_{4}$ bend, but in the eastern and southeastern part of the archipelago sector II trends southwards subparallel to the trends of the sandwich layers. The dyke rock in sector II is recrystallised to varying degrees and is a metadolerite with relic doleritic texture. The primary silicate minerals are often subdivided into smaller grains and amphibole (uralitic-hornblende) may be a main constituent. Both metadolerites with substantial amounts of original ig- 


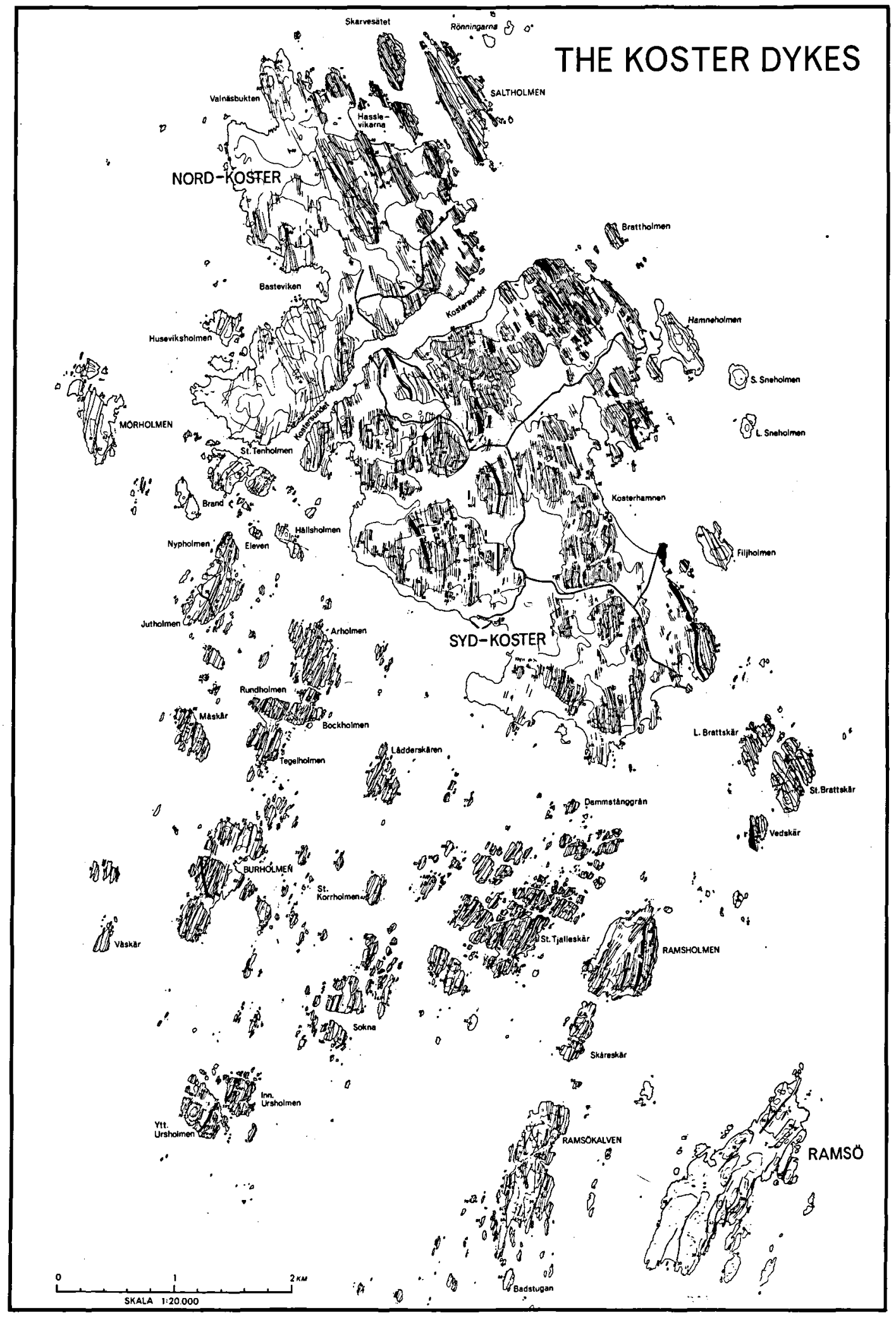

Fig. 4. Map showing the Koster dyke swarm. 
neous mineralogy and pure amphibolites occur. The olivine has reacted to form aggregates of ilmenite, biotite, orthopyroxene $( \pm)$, hornblende and sphene $( \pm)$. Relict chilled margins are always present, but commonly narrow sheared margins are also seen in the dykes. The sheared margins are mostly thinner than $1 \mathrm{~cm}$ and are seen as foliated biotite-chlorite-bearing amphibolite. Thinner completely recrystallised dykes $(<1 / 2 \mathrm{~m})$ may sometimes have a steep sigmoidal foliation. Locally the dykes show asymmetric folds and boudinage structure, and discordant minor shears also occur.

In sector III the layers are highly strained and a pronounced linear fabric is developed in all $D_{4}$ affected rocks. The dykes are amphibolitised throughout and mineral (hornblende) as well as aggregate (plagioclase) lineations are developed. Mimetic chilled margins are present in the thicker dykes, in spite of the recrystallisation. Only in a few thick dykes can a relict doleritic texture be observed in the centres. $A D_{4}$ foliation has formed in some layers together with the lineation, but the degree of foliation seems to depend on the competence of the individual layers. Thus the foliation is well expressed in incompetent dyke layers, where it is oblique, but with very high strain it becomes parallel to the dyke walls. Most gneiss layers have very weak or no $D_{4}$ foliation. Boudinage of the dyke layers is frequently seen and sometimes also asymmetric $D_{4}$ folds on mesoscopic and microscopic scale. Syn$\mathrm{D}_{4}$ garnets have been formed in some dyke layers. The subdivision of the sector into the four subsectors (A, B, C and D) is on structural criteria given later.

\section{The pre- $\mathrm{D}_{4}$ sandwich structure}

The unaffected pre- $\mathrm{D}_{4}$ sandwich structure can be studied in sector I, but structures related to the shapes of the dykes are also recognisable in the highly stained area. In the sandwich the shape and thickness of the layers is directly related to the shape, width and spacing of the Koster dykes.

\section{The Koster dyke layers and their structural relations}

The Koster dyke swarm consists of at least 700 dykes, which in sector I trend NNE-SSW and have a moderately steep dip to WNW. Fig. 4 shows the dyke swarm; at least $90 \%$ of the exposed dykes are present on this map. Almost all dykes in sector I have a subparallel trend, but a few have a NE-SW or a NW-SE trend. These deviating dykes are called the NE dykes and the NW dykes respectively, while the common dykes are the NNE dykes. The age relations between the NE and NW dykes are unknown, but they are both older than the NNE dykes and possibly they occupy conjugate fractures. Another feature which appears from the map is that the crust is regularly dyked with almost the same dyke frequency throughout sector I. However, the density of the dyke swarm is less in both the extreme northwest (the Mörholmen-St. Tenholmen area) and southeast (Ramsö). This may indicate the northwest and southeast limits of the intensely dyked part of the dyke swarm, the width of which is at least $8 \mathrm{~km}$. Within these $8 \mathrm{~km}$ the crust has expanded more than $1200 \mathrm{~m}(15 \%)$ by successive dyke by dyke injection.

The NNE dykes (Fig. 5) are regular tabular bodies somtimes showing en echelon structures or, less frequently, bifurcation. Dyke intersections are frequently seen. The NNE dykes and their relations to the host rock were systematically studied in order to find out if the dyke opening was related to shear movement in the host rock or to simple dilatation normal to the dyke walls. The many older minor dykes and veins in the host rocks facilitate three dimensional investigations, and it can be demonstrated that dyke opening was by simple dilatation. Inspections of several dyke terminations indicate that the dykes were not injected into older shears, as no shears continue in the host rock from the terminations.

The NNE dykes define the parallel trends in the dyke swarm, but unfortunately very few dykes can be traced without interruption over several kilometres. To outline the trends in the dyke swarm and to establish marker horizons in the multilayered sandwich, the map Fig. 6 has been constructed. The hypothetical 'master' dykes in this map were chosen to be equidistant in a selected section normal to the dyke trend in sector I. The continuations of the 'master' dykes marked in this section were then drawn parallel to the dyke trend seen in the individual exposures. The first master dyke to be drawn was 

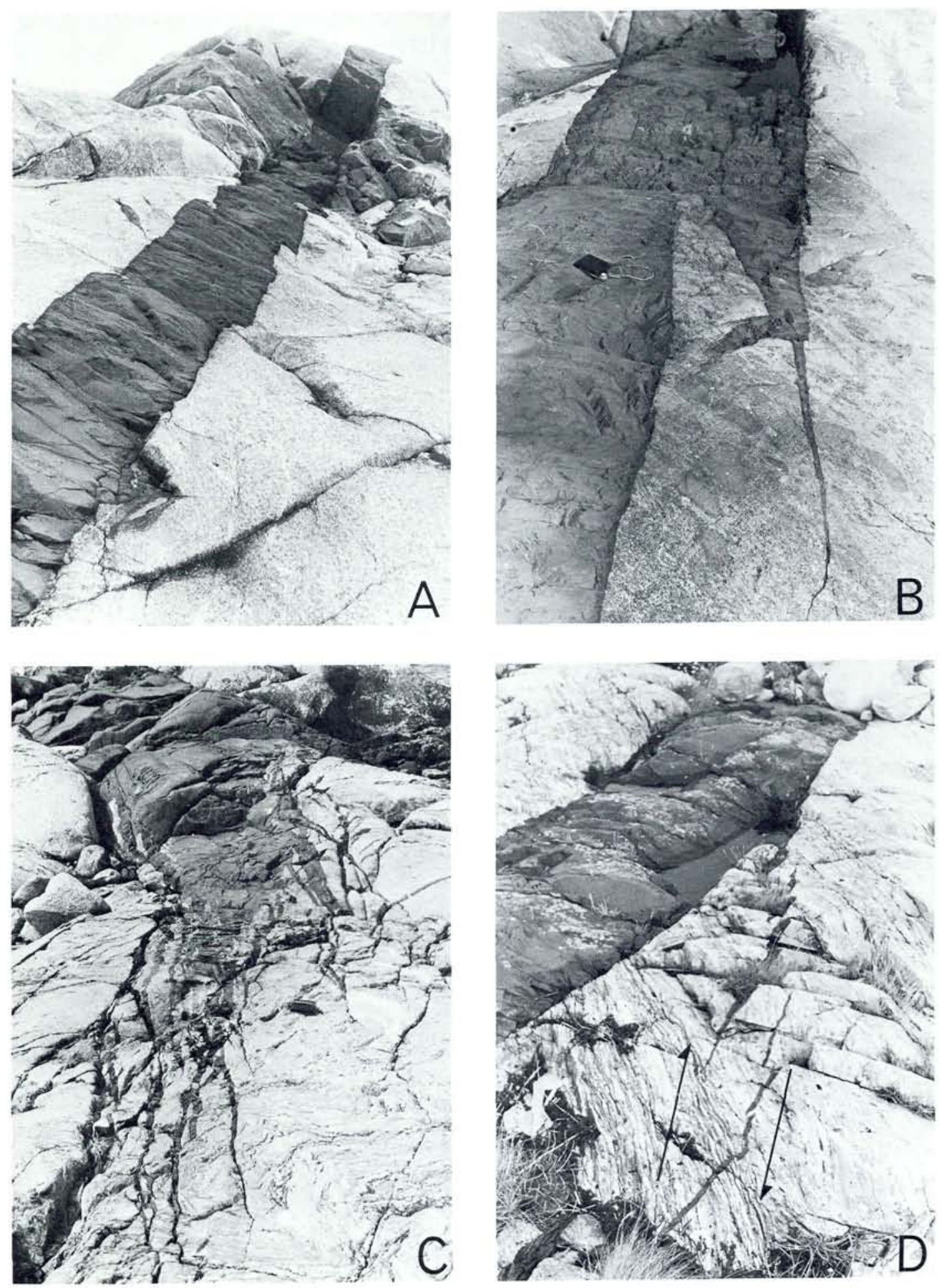

Fig. 5. Examples of structures formed by the NNE dykes. A) Dyke from sector I with ragged contacts. B) En bajonet structure (sector I). C) Horse-tail termination of a dyke branch (sec-

tor II). D) En echelon apophysis presumably formed by a dextral shear accompanying the dyke opening (sector I). 


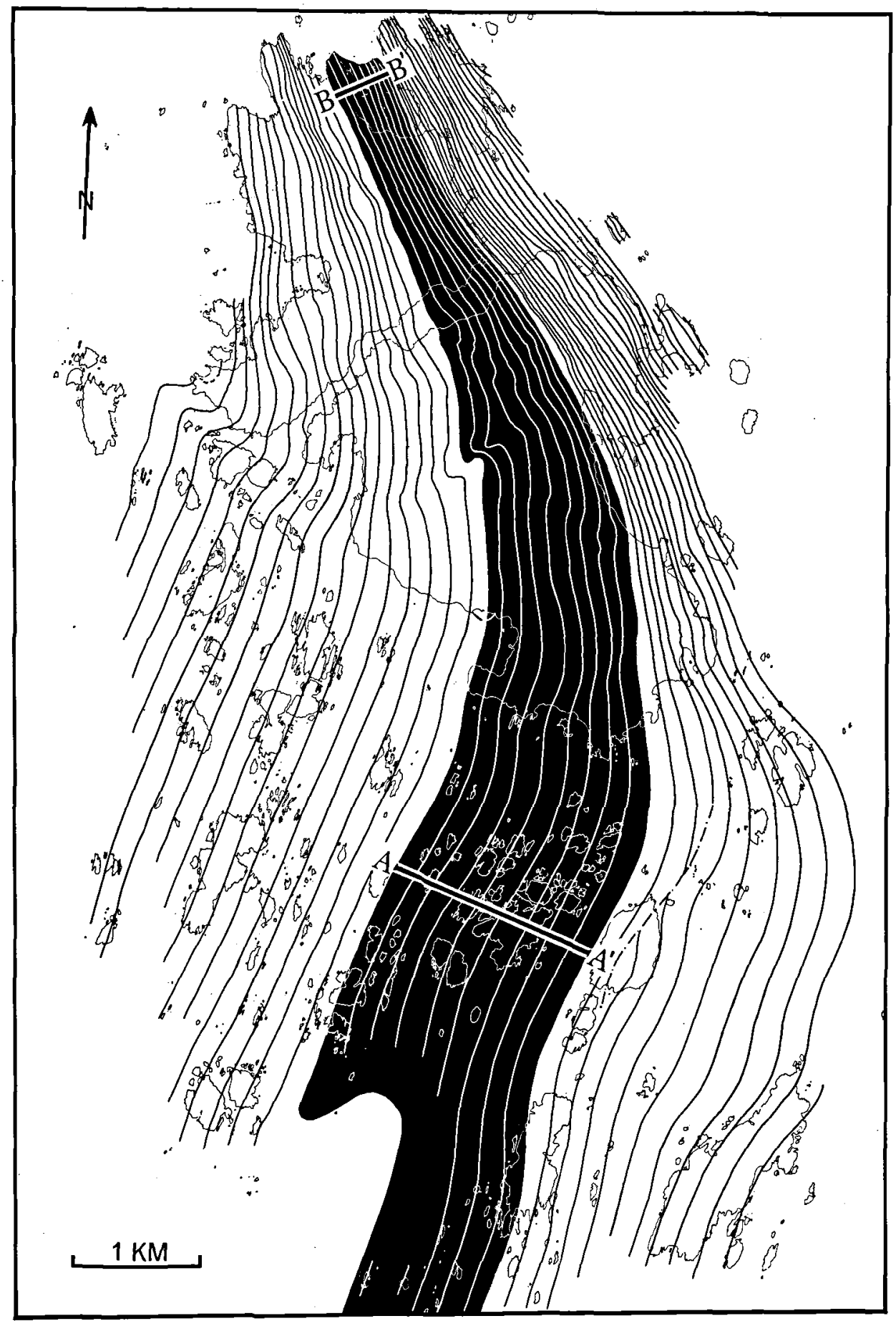

Fig. 6. Map showing the trends of hypothetical 'master dykes' within the Koster dyke swarm. The megalayer shown has been selected for investigation of dyke width, dyke intensity and strain analysis. 

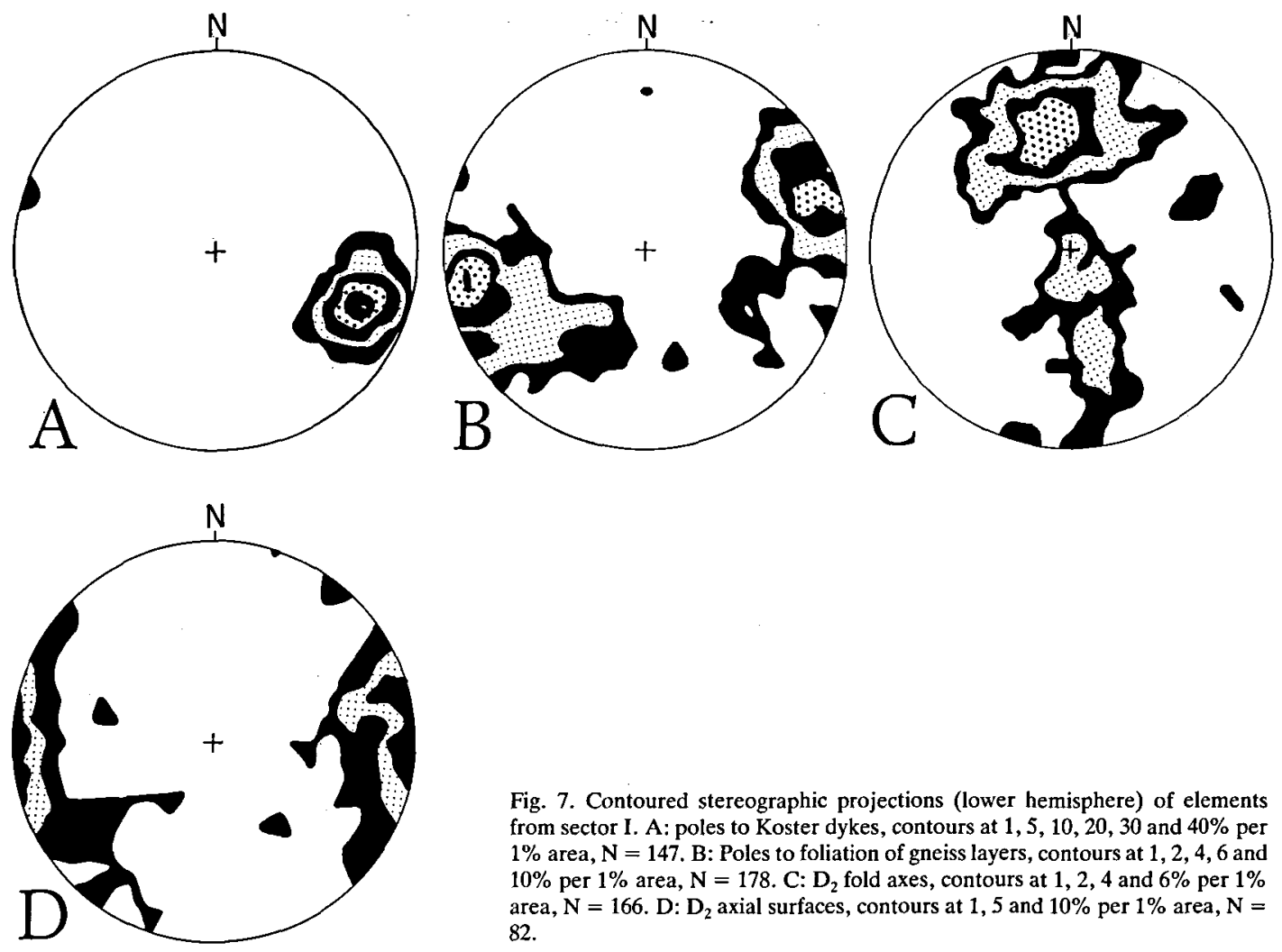

Fig. 7. Contoured stereographic projections (lower hemisphere) of elements from sector I. A: poles to Koster dykes, contours at 1, 5, 10,20,30 and $40 \%$ per $1 \%$ area, $\mathrm{N}=147$. B: Poles to foliation of gneiss layers, contours at $1,2,4,6$ and $10 \%$ per $1 \%$ area, $N=178$. $C: D_{2}$ fold axes, contours at $1,2,4$ and $6 \%$ per $1 \%$ area, $\mathrm{N}=166 . \mathrm{D}: \mathrm{D}_{2}$ axial surfaces, contours at 1,5 and $10 \%$ per $1 \%$ area, $\mathrm{N}=$ 82.

within the megalayer shown in Fig. 6, where the most continuous trend is seen because of the short distances between the exposures. If this dyke is taken to represent a real undeformed dyke in the south, it is assumed that the deviation in the north between the hypothetical 'master' dyke and the dyke, which it in fact represents is less than $100 \mathrm{~m}$. This assumption is believed to be reasonable because of the excellent exposures, the parallelism between the dykes and the frequency of the dykes.

The degree of the conformity between the NNE dykes in sector I appears from Fig. 7A. The mean strike is $22^{\circ}$ while the mean dip is $67^{\circ} \mathrm{W}$. The dip variation is normally distributed (Fig. 8) with $74.4 \%$ of the measurements $(\mathrm{N}=147)$ in the interval $55^{\circ}-74^{\circ} \mathrm{W}$.

The variation in the thickness of the NNE dykes has been studied in completely exposed sections close to the line $\mathrm{AA}^{\prime}$ in the megalayer shown in Fig. 6. These exposed sections cover

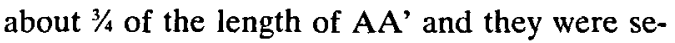
lected to be as long as possible without any break in the exposure. All dykes have been measured in these sections and a total of 146 widths have been recorded. The accuracy of the measurements is believed to be $\pm 10 \%$. The frequency of the dyke widths is shown in Fig. 9 and as seen most dykes have thicknesses below $2.5 \mathrm{~m}$. The greater the width, the less frequently this width is represented. The mean width is $2.1 \mathrm{~m}$ with a standard deviation of 2.0. If dykes thinner than $0.1 \mathrm{~m}$ with a standard deviation of 2.0 . If dykes thinner than $0.1 \mathrm{~m}$ are omitted the mean will be $2.2 \mathrm{~m}$ with the same standard deviation. The thickest dyke measured was $9 \mathrm{~m}$ thick, but a few thicker dykes do occur in the archipelago. The maximum thickness is estimated to be $30 \mathrm{~m}$. From the measurements in sections parallel to AA' it is furthermore found that dykes occupy $18.8 \%$ of the rock volume in this megalayer.

\section{The gneiss layers}

The lithologically composite gneiss layers are 


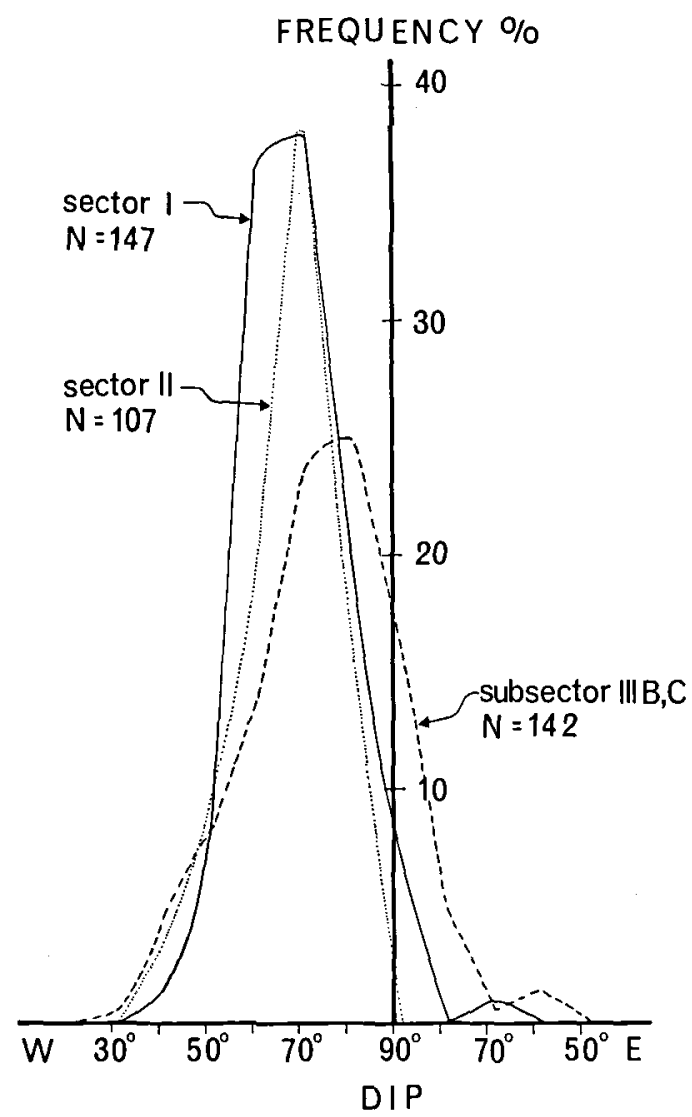

Fig. 8. Dip frequency of the layers in sector I, II and subsector IIIB and C.

mostly thinner than $20 \mathrm{~m}$, but no systematic measurement of the width of the gneiss layers has been carried out. The complex pre- $\mathrm{D}_{4}$ evolution of the gneiss layers is indicated in Table I. The crustal material underwent three major phases of deformation prior to the dyking. Of these phases of deformation $\left(D_{1}, D_{2}\right.$ and $\left.D_{3}\right)$, only $D_{2}$ is of importance in the present context as the structural pattern on a mesoscopic as well as a megascopic scale is controlled and dominated by $D_{2 a}$ and $D_{2 b}$ structures. It is remarkable, that in spite of these deformations the gneisses were left without a linear fabric and even the formation of a planar fabric is restricted. This is demonstrated by the granitoids in which only a slight S-fabric (Flinn 1965) has been developed.

The major finite structural pattern is shown in Fig. 10, while Fig. 11 shows a reconstruction of the pre-Koster dyke situation in the gneisses. From the structural maps it is seen that the major
pre-Koster dyke pattern is formed by interference between $\mathrm{D}_{2 \mathrm{a}}$ folds with NW-SE trending axial surfaces and $D_{2 b}$ folds with axial surfaces trending between $\mathrm{N}$ and $\mathrm{NE}$.

The $D_{2 a}$ folds occur in any scale. The mesoscopic folds vary generally from close to isoclinal folds often with flattened or sheared limbs (fold terminology according to Fleuty 1964). The axial surfaces are subvertical and trend NNW-SSE, while the plunge of the fold axes shows a spread in the axial surfaces from NNW through vertical to SSE (see Fig. 7).

The major pre-Koster dykes structure in the area is a large overturned $D_{2 b}$ antiformal structure with a NE-dipping limb in $\mathrm{N}$ and $\mathrm{S}$ Koster and an overturned WNW-dipping limb as seen on Ramsö. The axis of this structure plunges moderately towards NNE. In the southern part of Ramsö the overturned limb turns towards SSE, which raises the possibility that the whole major $D_{2 b}$ structure could be part of a Z-shaped fold pattern with NW-SE trending long limbs and NE-SW trending overturned short limbs. The minor $D_{2 b}$ folds are rather like the $D_{2 a}$ folds, but generally they are more open and they have fold axes plunging gently to moderately to $\mathrm{N}$ or $\mathrm{NE}$ and subvertical axial surfaces. The superimposition of $D_{2 b}$ folds on $D_{2 a}$ folds has resulted in interference patterns of the 'refolded fold' type (type 3 of Ramsay 1967) and sometimes of dome-andbasin type (type 1 of Ramsay).

The orientation of foliation and $D_{2 a}+b$ fold

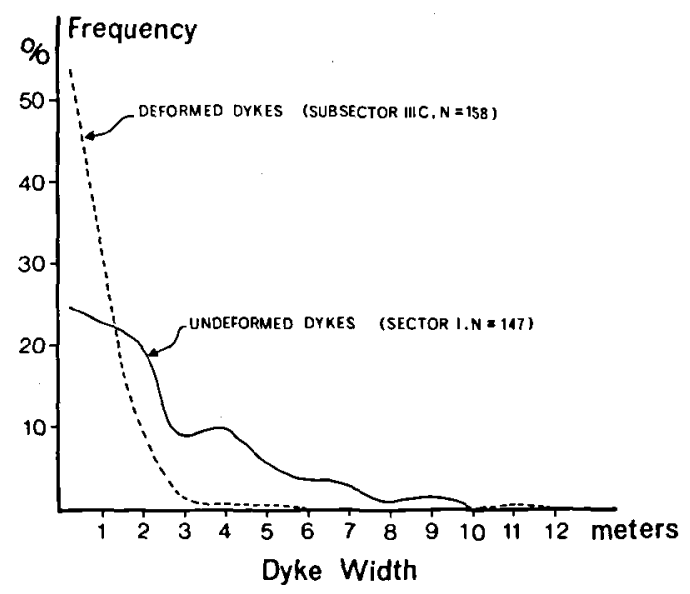

Fig. 9. Frequency of the width of the Koster dyke layers in undeformed and deformed state. 
axes and axial surfaces is shown in Fig. 7. The fold axes show a spread in an almost vertical surface which is the mean $D_{2 a}$ axial surface. The larger spread of the fold axes with northward plunges is due to the $D_{2 b}$ folds, which only have a northward plunge.

When these orientations of structural elements are compared to the orientation of the undeformed Koster dykes and the sandwich structure, it is seen that whereas parallelism between the foliation and the sandwich layers is rare, it may happen that the fold axes and axial surfaces are parallel to the sandwich layers.

\section{The $\mathrm{D}_{4}$ deformation}

The detailed study of the $\mathrm{D}_{4}$ deformation has revealed progressive stages $\left(D_{4 a}, b, c, d d\right.$ accompanying and outlasting the formation of the regional bend of the pre- $D_{4}$ sandwich. Before describing the structures in detail, a summary of the evolution of the $D_{4}$ structures is given.

The regional bend of the pre- $\mathrm{D}_{4}$ sandwich is a large gentle synformal fold, the Kyrkosund synform (Fig. 12), with a round wide hinge and almost straight limbs, which however show a gentle warpening in the SE part of the southern limb and conjugate folds in the northern limb. The axis of the synform plunges $303^{\circ} / 66^{\circ}$ and the orientation of the axial surface is $130^{\circ} / 87^{\circ} \mathrm{SW}$. Increasing $\mathrm{D}_{4}$ strain is seen in the progressive thinning of the layers northwards in the northern limb and in the formation of a succession of minor structures. The thinning of the layers can be seen in Fig. 2, which also shows that the strain increases with increasing anticlockwise rotation of the northern limb. Thus the NW-SE-trending zone of subsector IIIC and D shows the strongest strain.

The formation of the Kyrkosund synform is referred to the $D_{4 a}$ stage in the $D_{4}$ succession and related to this stage is also the initial development of a moderately NW plunging stretching lineation $\left(\mathrm{L}_{4}\right)$ (sector III), the generation of ductile shears in some dyke layers (sector II and III), the formation of boudins (sector II and III), and the development of asymmetric folds with axes parallel to the streching lineation (sector III). The results of the further progress of $\mathrm{D}_{4}$ are only seen in sector III.
At the onset of the $D_{4 b}$ stage the present trend of the northern limb was already established, but during $\mathrm{D}_{4 \mathrm{~b}}$ this limb became strongly stretched horizontally in a NW-SE direction parallel to its trend. During the $\mathrm{D}_{4 \mathrm{~b}}$ stretching event the development of $\mathrm{L}_{4}$ continued, and both $\mathrm{L}_{4}$ and the other older structures were rotated towards the stretching direction of $D_{4 b}$, which was subhorizontal with a trend parallel to the initial direction of $\mathrm{L}_{4}$. The amount of strain increases in a northeastwards direction as the plunge of $\mathrm{L}_{4}$ decreases. After the formation of the main stretching fabric in the rock mass, necks, boudins and gentle folds with horizontal axes were developed. This late $D_{4 b}$ inhomogeneous deformation played only a minor role; the $D_{4 b}$ stage was mainly a phase of homogeneous stretching.

$D_{4 c}$ events resulted in upright asymmetric folds which refolded the $\mathrm{L}_{4}$ lineation. These folds occur mainly in the northeastern sector (subsector IIID), but they also occur locally farther to the west as minor gentle structures. No new lineation was formed. The new $\mathrm{D}_{4 c}$ fold axes show a spread in a vertical NW-SE trending axial surface.

The $D_{4 d}$ stage represents the final recorded stage in the $\mathrm{D}_{4}$ succession. Evidence of this step is found in subsector IIID where asymmetric folds were superimposed on the older $\mathrm{D}_{4}$ structures. The $D_{4 \mathrm{~d}}$ fold axes plunge moderately to the NW, while the axial surfaces trend obliquely to the main $D_{4}$ fabric.

\section{The structural relations in the Kyrkosund synform The orientation of the sandwich layers}

In Fig. 13 the variation in mean dip per $0.5 \mathrm{~km}^{2}$ of the sandwich layers is shown. This map was constructed at a scale of 1:10.000 by using a grid with a spacing of $250 \mathrm{~m}$. At each point in the grid the mean value of the dip within a circle with an area of $0.5 \mathrm{~km}^{2}$ centred on the point was recorded. Contours for mean dips of $80^{\circ}, 70^{\circ}$ and $60^{\circ} \mathrm{W}$ were drawn by linear interpolation. The angle of dip was measured from the west, which means that a dip of $60^{\circ} \mathrm{E}$ became a dip of $120^{\circ}$ in the calculation of the mean dip.

The mean dip per $0.5 \mathrm{~km}^{2}$ varies mainly between $60^{\circ}-80^{\circ} \mathrm{W}$ with a slightly steeper mean dip in the northern limb of the Kyrosund synform. 


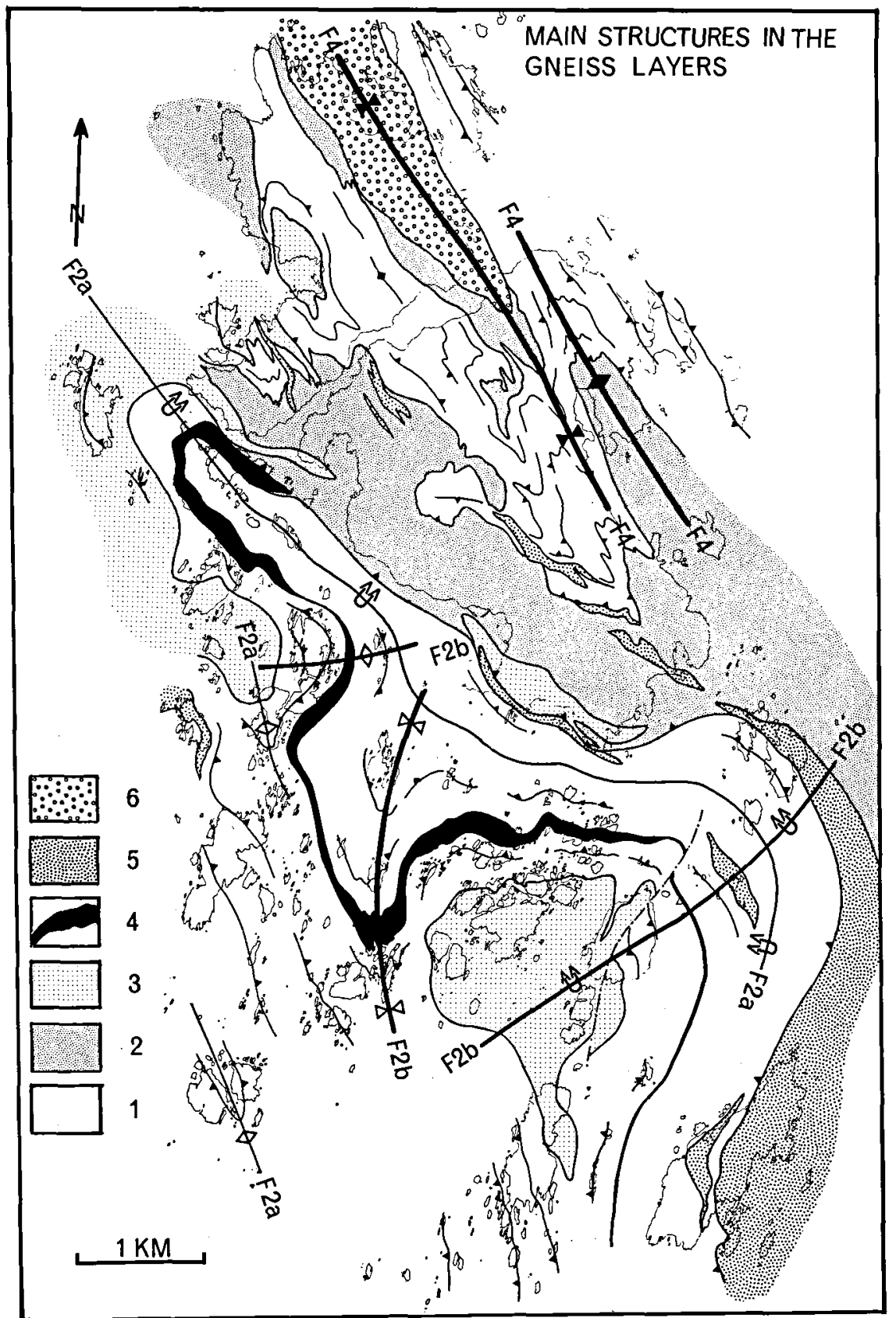

Fig. 10. Main structures in the gneiss layers. 1) Stora Le Marstrand gneisses and migmatites. 2) Tonalitic gneiss. 3) Granitic to trondhjemitic granites (more of less gneissified). 4) Agmatite. 5) Augen gneiss. 6) Sheeted granite (strongly deformed).

Two areas have values over $80^{\circ} \mathrm{W}$, while three areas show lower values between $60^{\circ} \mathrm{W}$ and $50^{\circ} \mathrm{W}$. Two areas with steep mean dip show the same mean dip variation $-80^{\circ} \mathrm{SW}-86^{\circ} \mathrm{NW}$ in the northern steep area and $80^{\circ} \mathrm{W}-87^{\circ} \mathrm{E}$ in the small area in the hinge. There is no $D_{4}$ structural reason for these steep areas and they are regarded as a pre $\mathrm{D}_{4}$ features of the sandwich. Futhermore they are positioned at same level in the sandwich as the $70^{\circ}-80^{\circ} \mathrm{W}$ areas on the southern limb. 


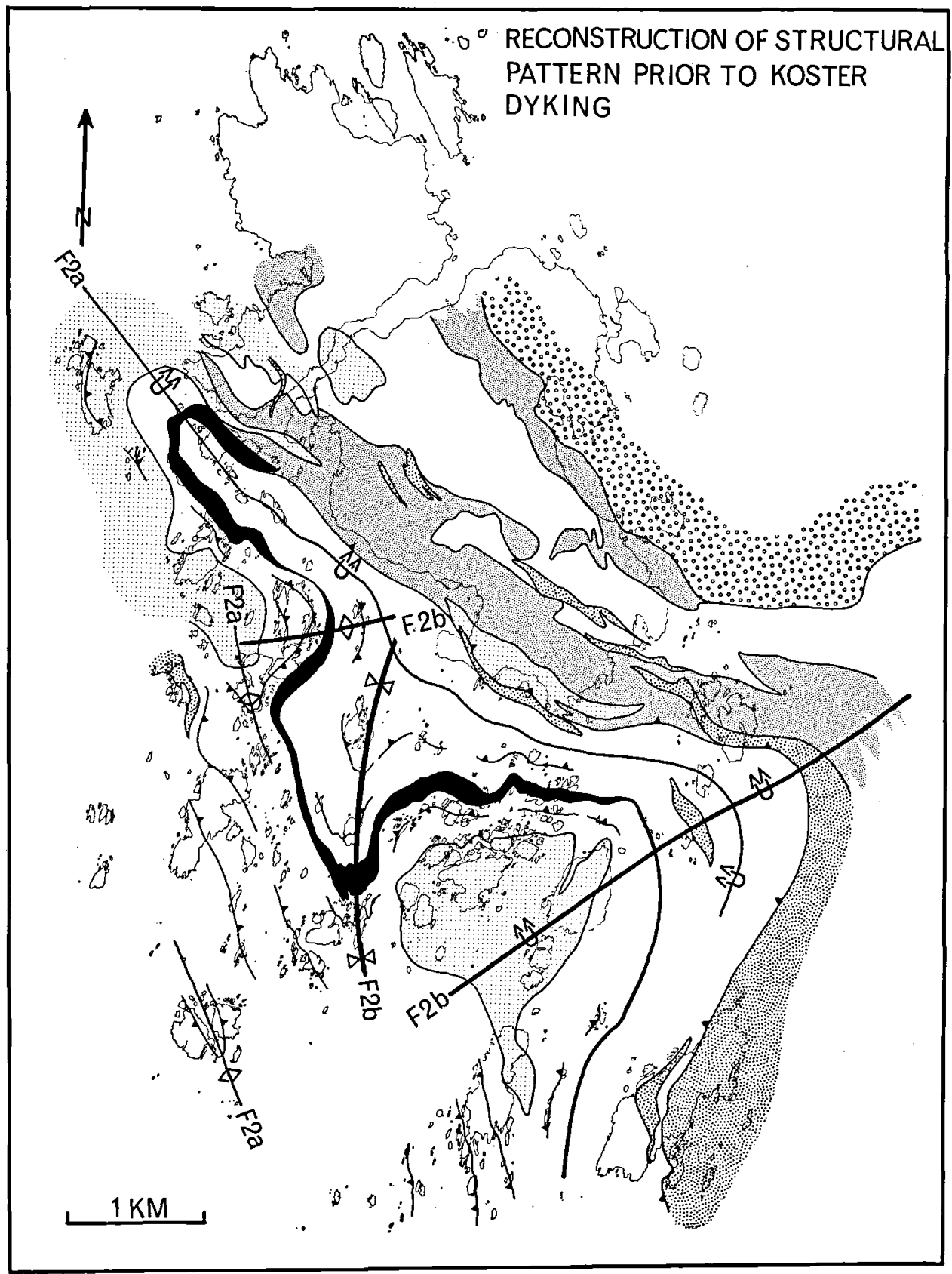

Fig. 11. Reconstruction of the structural pattern prior to Koster dyking.

These three areas of steep dip are partially connected to the occurrence of massive granitic plutonites (compare Fig. 13 and 10), which possibly refracted the initial joints into which the dykes was emplaced and caused the steep dips. The three areas with low dipping layers are presumably related to the $\mathrm{D}_{4}$ deformation as described later.

The frequency of dip values of the sandwich layers in the three main sectors is shown in Fig. 8. 


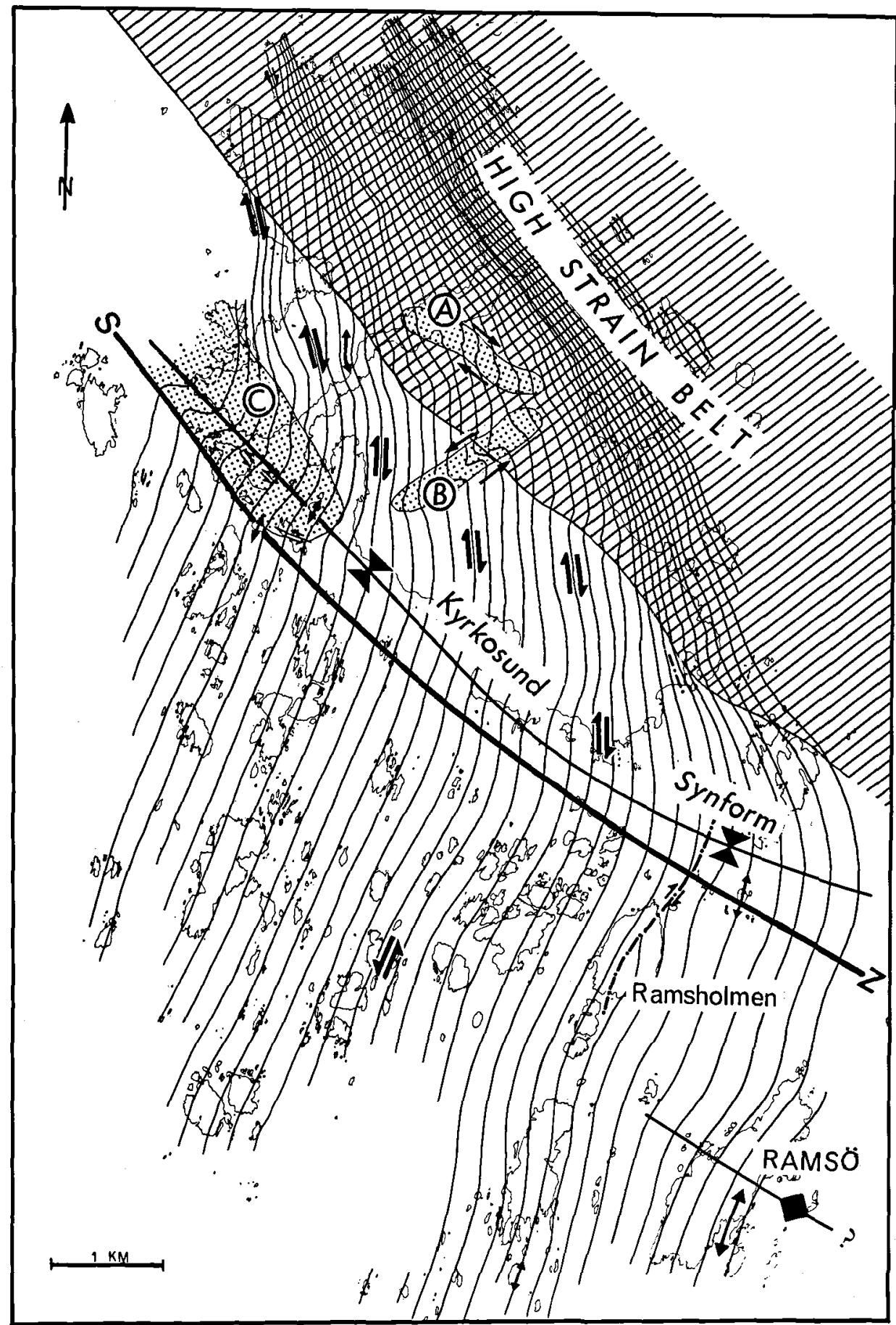

Fig. 12. Synoptic map showing important $D_{4}$ features as: the high strain belt, the boundary of the Koster shear zone (S-Z), the Kyrkosund synform, the layer parallel shearing, the conjugate areas $(A, B$ and $C)$ of late $D_{4 a}$ deformation and the location of layer parallel stretching $(\longleftrightarrow)$ (boudinage) in sector II. 


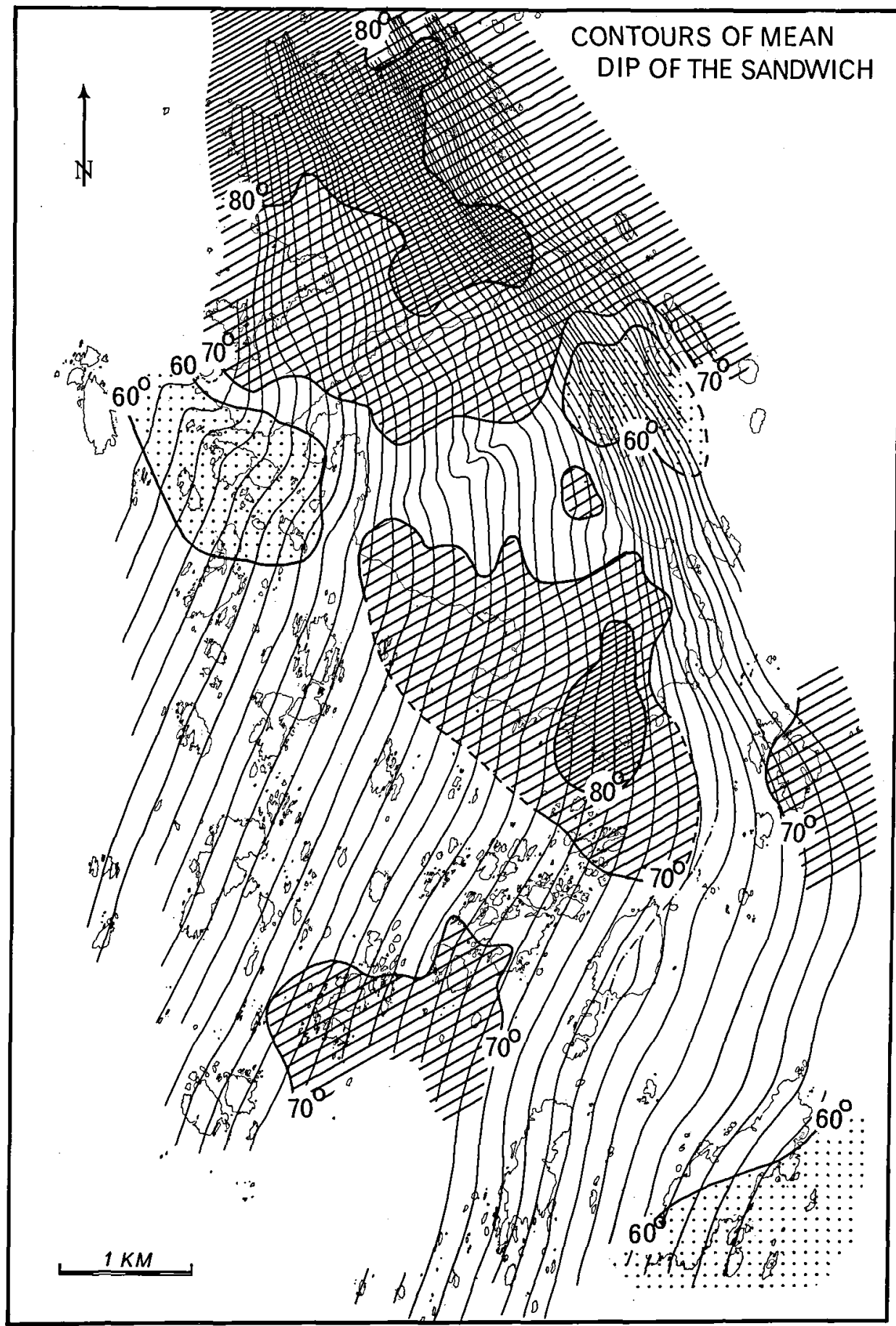

Fig. 13. Contours of mean dip of the sandwich layers.

The statistical mean dips are $67^{\circ} \pm 8^{\circ} \mathrm{W}, 70^{\circ}$ $\pm 12^{\circ} \mathrm{W}$ and $75^{\circ} \pm 17^{\circ} \mathrm{SW}$ in sector I, II and III respectively. The mean dip thus becomes gradually steeper from sector I to sector III. The difference is only $8^{\circ}$, but enough to explain the slightly higher mean dip per $0.5 \mathrm{~km}^{2}$ in the northern 

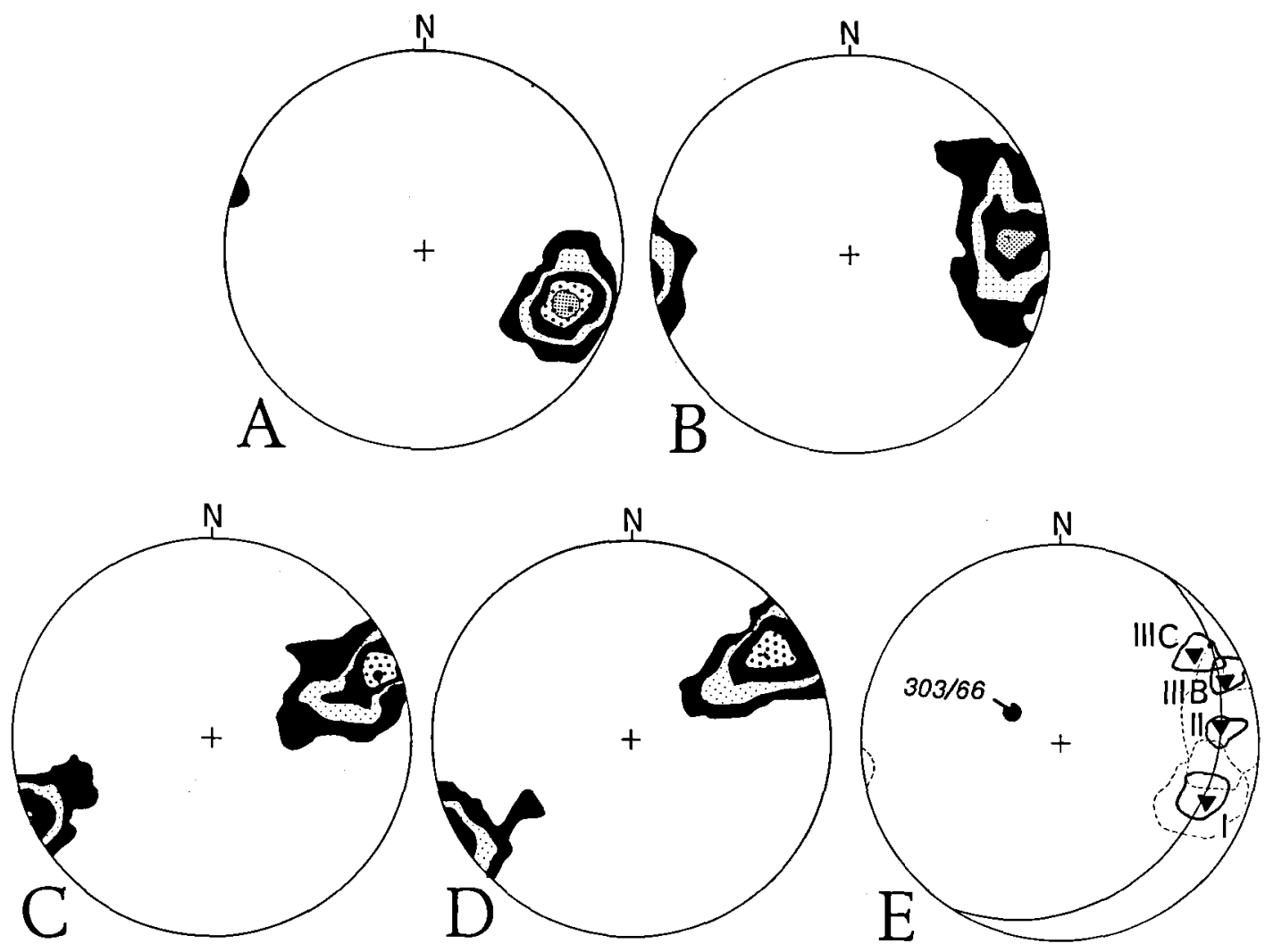

Fig. 14. Stereographic projections (lower hemisphere) showing the rotation of the sandwich layers in the Kyrkosynd synform. A: poles to the sandwich layers of sector I, contours at $1,5,10,20,30$ and $40 \%$ per $1 \%$ area, $N=147$. B: Poles to sandwich layers in the hinge of the Kyrkosund synform (part of sector II), contours at 1,5,10 and $20 \%$ per $1 \%$ area, $N=107$. C: Poles to sandwich layers of subsector IIIB, contours at $1,5,10,20$ and $30 \%$ per $1 \%$ area, $N=80$. D: Poles to sandwich layers of subsector IIIC, contours of 1,5 , 10 and $20 \%$ per $1 \%$ area, $N=62$. E: Determination of the fold axis of the Kyrkosund synform by plotting contours from $A$ ( 5 and $30 \%)$, B (5 and $20 \%), C(20 \%)$ and D (20\%). Triangles indicate maximum concentrations.

limb. The dip variation is also significantly larger in the highly strained sector III than in sectors I and II because the late $\mathrm{D}_{4 \mathrm{~b}}$ shortening formed gentle folds with flat-lying axes parallel to $L_{4}$.

The distribution of the poles to the sandwich layers shows a strong concentration in the three stereographic plots for sector I, II, and IIIB and $\mathrm{C}$ (Fig. 14). Following the orientations of the sandwich layers from the southern limb (Fig. 14A) of the Kyrkosund synform into the hinge (Fig. 14B) and further into the highly strained part of the northern limb (Fig. 14C, 14D), the circular area of the poles of the southern limb rotates around the $303 \% 6^{\circ}$ fold axis of the Kyrkosund synform (Fig. 14E). In subsectors IIIB and $\mathrm{C}$ the distribution of the poles has changed markedly to elliptically shaped areas defining vertical planes trending $66^{\circ}$ and $57^{\circ}$ for subsectors IIIB and $\mathrm{C}$ respectively. The more $\mathrm{E}-\mathrm{W}$ orientation of the poles in subsector IIIB is due to a slightly lesser rotation around the $303^{\circ} / 66^{\circ}$ axis than seen in subsector IIIC, but the maximum concentration of the poles in subsector IIIB fits with the great circle defined by the poles from sector I and II. The maximum concentration of the poles in subsector IIIC is slightly steeper than that of poles in subsector IIIB. This small deviation could perhaps be due in part to the primary orientation of the layers, but most likely the maximum has been rotated away from the great circle to its present position by $D_{4 b}$ (see p. 183). The rotation has taken place in the vertical plane defined by the poles. This plane will be shown later to coincide with the $\mathrm{YZ}$ plane of the strain ellipsoid, while the axis of rotation $\left(147^{\circ} 0^{\circ}\right)$ is parallel to the streching lineation and the strain- $X$ axis. 
The axial surface of the Kyrkosund synform can be read from the map (Fig. 12) to have a strike of about $130^{\circ}$, while the dip can be found from the orientation of the axis to be $87^{\circ} \mathrm{SW}$. The interlimb angle is $127^{\circ}$.

\section{$\mathrm{D}_{4 \mathrm{a}}$ shear deformation of layers in the sandwich}

The first signs of $\mathrm{D}_{4}$ deformation are seen in the dyke layers of sector II. Besides the rotation of the layers in this sector there is frequently a foliation along and parallel to the dyke margins or a sigmoidal foliation across thin dykes and apophyses. These planar structures $\left(\mathrm{S}_{4 \mathrm{a}}\right)$, with very few exceptions, are restricted to the dyke layers.

The foliated margins of dyke layers are developed in the thicker dykes $(>1 \mathrm{~m})$; the width of the foliated zone is often less than $1 \mathrm{~cm}$. If the pre-dyke structures of the gneiss layers on either side of a dyke with foliated margins are compared a small $(<1 \mathrm{~m})$ dextral displacement is seen on horizontal surfaces, while vertical sections across such dykes do not indicate any displacement. This means that the foliated margins were formed as a result of horizontal dextral shearing with the shear couple parallel to the layers.

The sigmoidally foliated dykes (Fig. 15) are always thinner than $1 \mathrm{~m}$ and mostly one a few $\mathrm{dm}$ thick. They have undergone complete synkinematic recrystallisation and have a subvertical foliation. The orientation of the sigmoidal foliation as well as the displacement of the unaffected host rock structures show that the foliation was formed by subhorizontal dextral shearing, and that the dyke layers behaved incompetently during the deformation. The dextral displacement of structures in the host rock to sigmoidally foliated dykes may reach $5 \mathrm{~m}$ in sector II. The amount of dextral shearing increases northwards in the northern limb of the Kyrkosund fold and displacements exceeding $10 \mathrm{~m}$ have been observed in sector III (see Fig. 16). With larger displacements it becomes very difficult to compare the host rock structure in either side of the sheared dyke layer. With increasing shear strain (subhorizontal desplacement $>10 \mathrm{~m}$ ) the sigmoidal foliation becomes gradually transformed to a layerparallel foliation.

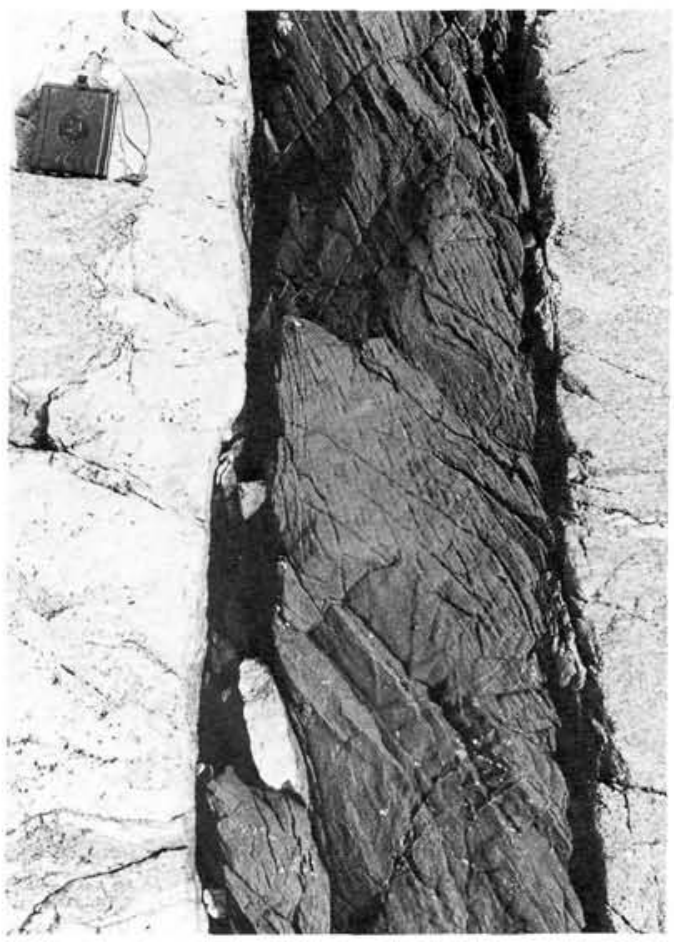

Fig. 15. Sigmoidal foliation in a thin Koster dyke of sector II.

In sector II only dextral shearing of the layers is observed, while in sector III there are sinistrally sheared layers, but they are very few in comparison to the common dextrally sheared layers. In sector II as well as in sector III sheared dykes occur side by side with unsheared dykes, but the number of sheared dykes is much larger in sector III than in sector II. The subhorizontal layer-parallel shearing is indicated in Fig. 12.

The most important features related to the horizontal dextral shearing are: 1) the localisation of the shear deformation in incompetent layers, 2) the increasing amount of dextral displacement with increasing distance northwards from the hinge line, 3) development of $S_{4 a}$ foliation as a sigmoidal or a layer-parallel foliation. Features 1 and 2 are characteristic features of typical flexural slip folds as described in the textbooks (e.g. Turner \& Weiss 1963, Hills 1963, Whitten 1966, Ramsay 1967). Thus, assuming the Kyrkosund synform to be a flexural slip fold with an almost fixed southern limb, rotation about its steep fold axis would have given rise to horizontal shear movements parallel to the layers in 

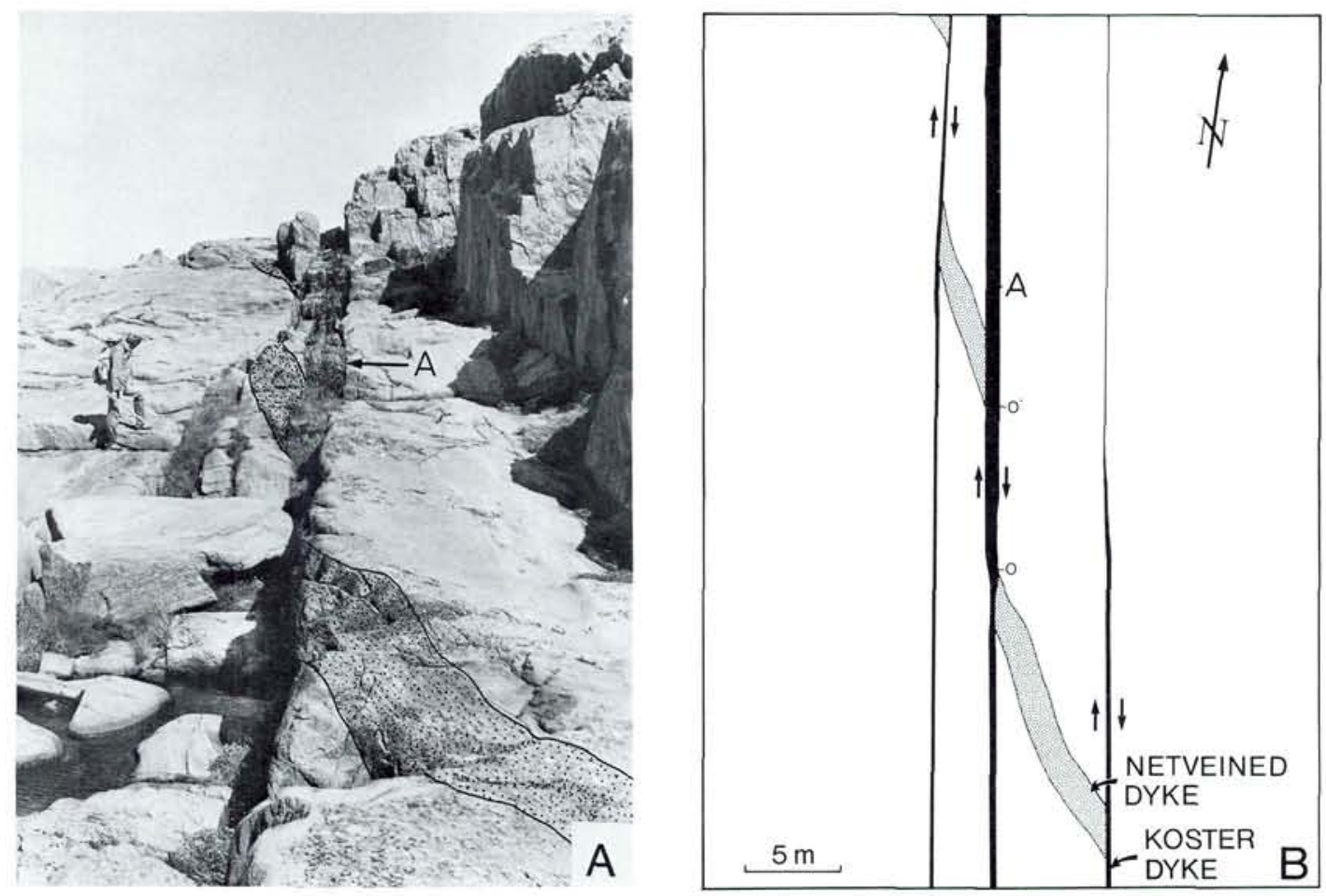

Fig. 16. Dextral sence of shearing located to Koster dykes. The dyke A in the photo corresponds to dyke A of the sketch map (Fig. $16 \mathrm{~B})$. The dextral displacement $\left(0-0^{\circ}\right)$ along dyke $\mathrm{A}$ is $9 \mathrm{~m}$. The thin dyke to the right in the sketch map can not be seen in the photo.

the northern limb. As the northern limb was rotated anticlockwise the shear displacement here should be clockwise (dextral), as is actually seen.

In the southern limb evidence of a slight rotation is found in the small sector II area enclosed within sector I. In this area sinistral shearing of dyke layers, formation of S-shaped folds and necking occur. The axes of folds and necks have directions of $270^{\circ}-290^{\circ}$ and steep plunges of about $70^{\circ}$. The fold axes are thus comparable to the fold axis of the Kyrkosund synform. The asymmetry of the folds and the sinistral shearing accord with a flexural slip mechanism for the formation of the Kyrkosund synform, which demands S-shaped folds and sinistral shearing within the southern limb.

\section{Local patterns of the $\mathrm{D}_{4}$ deformation}

Within the Kyrkosund synform there are four minor areas and also a ductile shear zone on Rams- holmen that require special mention. Three of the areas are marked as A, B, C on the structural map Fig. 12 while the fourth area is Ramsö.

Area A: This about $200 \mathrm{~m}$ wide area in sector II (Fig. 17) is characterised by Z-shaped asymmetric folding of the layers on a mesoscopic to megascopic scale. The folds have almost straight long limbs parallel to the general orientation of the sandwich layers and short limbs with a NE-SW strike and a low dip to the NW-. The length of the short limbs varies from 10 to $100 \mathrm{~m}$; minor open folds occur on these limbs. The fold axes plunge to $320^{\circ}$, parallel to the $\mathrm{L}_{4}$ stretching lineation. The axial surfaces have a NW-SE strike and are subvertical. $\mathrm{S}_{4 \mathrm{a}}$ foliation in the dykes is folded and the folding is accompanied by necking/boudinage of competent layers.

The structural pattern seen indicates a clockwise rotation in the rock mass around $\mathrm{L}_{4}$. Presumably this is due to a dextral ductile shear deformation, which on a horizontal surface has a dextral pattern of displacement. 
Area B: This NE-SW trending area about $150 \mathrm{~m}$ wide (Fig. 17) is poorly exposed in the central part, but a reclined fold structure closing to $S W$, axis ca. 325/20, axial surface ca. 50/20 NW, has been established. The upper limb is seen in the SE-facing cliff of Valfjället, while the lower limb is shown only by a westwards rotation of the dykes, when they are followed into the area from the south. The thick metadolerite dyke southeast of area B has been followed for $1.5 \mathrm{~km}$ as a straight dyke parallel to the sandwich layers. Where this dyke enters the lower limb of the fold the thickness decreases from $16 \mathrm{~m}$ to less than 8 metres within a distance of about $10 \mathrm{~m}$. This thinning is accompained by a complete recrystallisation and the metadolerite with relic doleritic texture has become a lineated amphibolite with a stretching lineation parallel to the fold axis. The same metadolerite occurs again north of the fold, but there as a boudin. If the position of the boudin is compared to that of the dyke south of the fold and to the trend of the sandwich structure undisturbed by the fold, it appears that the bou-

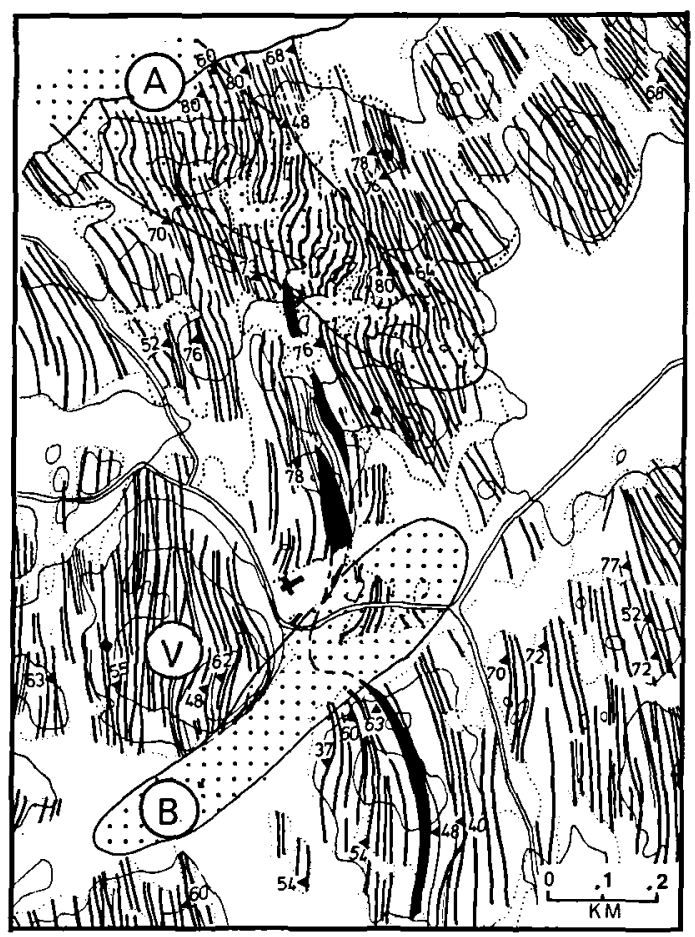

Fig. 17. Map showing the Koster dyke layers in the Valfjället area. $A$ and $B$ indicate the conjugate folds zones of Fig. 12, V $=$ Valfället.

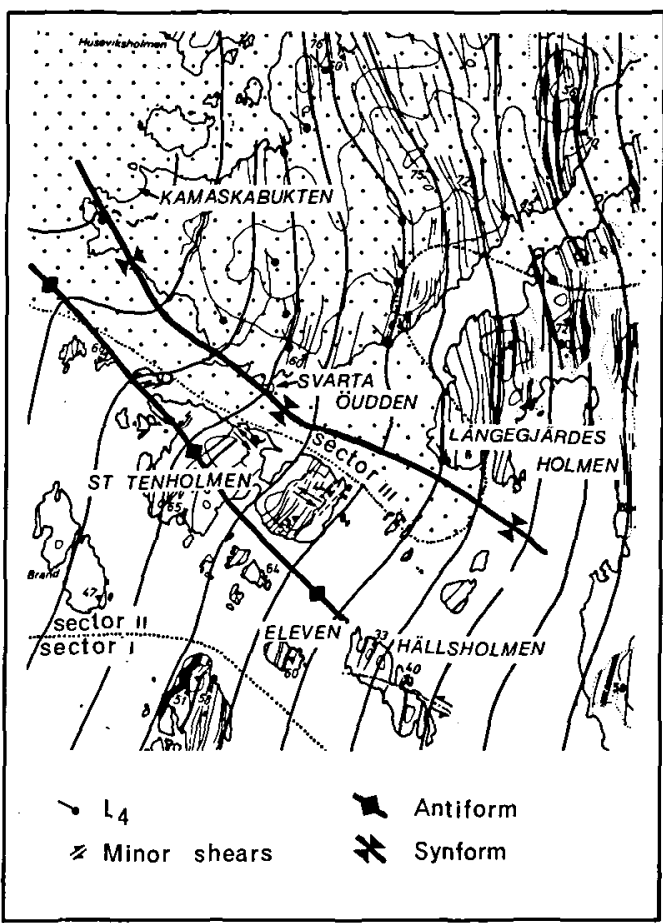

Fig. 18. Detailed map of area $\mathrm{C}$ (Fig. 12) and its surroundings.

din (and the surrounding sandwich) has been moved about $100 \mathrm{~m}$ to the west in connection with the folding, i.e. area $B$ is the site of a sinistral movement as shown on Fig. 12 .

Area C: This area are is situated on the innermost part of the hinge of the Kyrkosund synform (Fig. 18). There is an open antiform and an open synform, which both die out in a SE direction and give way to the normal hinge of the Kyrkosund synform controlled by the $303 \% 66^{\circ}$ fold axis. The axial surfaces of the folds in area $\mathrm{C}$ are subvertical and trend NW-SE just as the axial surface of the Kyrkosund fold, but the fold axes deviate markedly from the $303 \% 66^{\circ}$ axis, plunging $325 \%$ $20^{\circ}$. The fold pattern appears thus to be a younger pattern formed on the main hinge. The low mean dip per $0.5 \mathrm{~km}^{2}$ of the area (Fig. 13) is presumably caused by the folding.

The NW part of the area has a very few dykes, which makes it difficult to distinguish $\mathrm{D}_{4}$ structures in the gneiss layers from the small-scale $D_{2}$ structures as the $D_{2}$ structures are connected to a NW closing $D_{2 a}$ antiform with a NW-SE trending 
axial surface and a fold axis plunging to the north (see Fig. 10). The open upright $\mathrm{D}_{4}$ antiform is described by the dyke layers on St. Tenholmen and the small skerries NW of St. Tenholmen. The hinge of the adjoining synform is poorly exposed, but parasitic folds shown by the dykes can be seen on the tongue of land SW of Kamaskabukten, in the NE part of St. Tenholmen and in the SW part of Langegjärdesholmen. The gneisses are intensely small-folded between Kamaskabukten and Svarta oudden, but here the folds are presumably mainly $D_{2}$ folds, which to a certain extent have been reorientated towards $\mathrm{L}_{4}$. The axial surfaces of the folds dip subvertically to NE and they have a NW-SE trend.

Several boudins/necks with axes spreading around the moderately NW plunging $\mathrm{D}_{4}$ axes indicate a layer-parallel stretching related to the bending of the hinges. The boudins are only slightly separated. The first evidence of boudinage in sector II here is seen on Eleven and Hällsholmen.

In the area there are also a number of minor ductile shears (Fig. 19). These shears are steep to vertical with a NW-SE strike forming a large angle to the trend of the layers. All observed shears

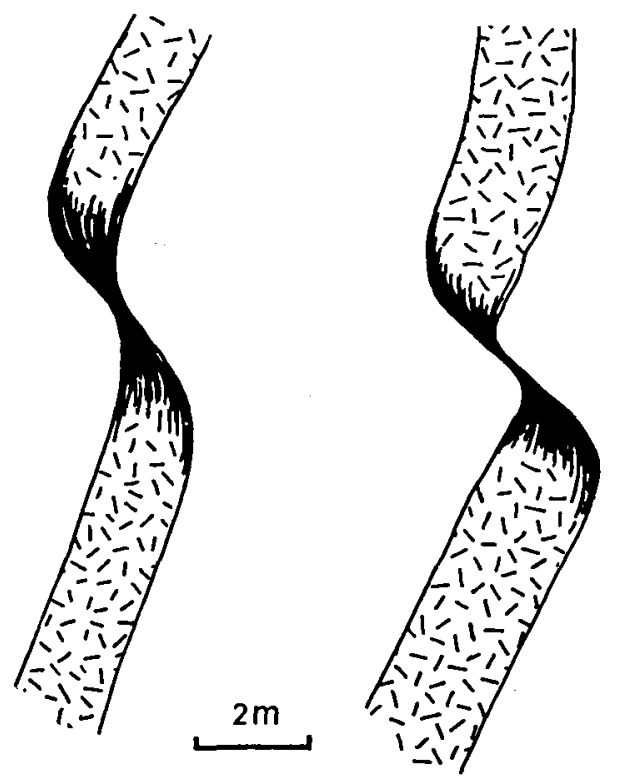

Fig. 19. Two examples of sheared metadolerite dykes, both of which have been deformed in vertical ductile shear zones. In the shear zone the dykes have developed a foliation and a stretching lination. are sinistral and the rocks involved become foliated and lineated with a stretching lineation in the general direction of $\mathbf{L}_{\mathbf{4}}$.

\section{Interpretation of the structural relations shown in areas $\mathrm{A}, \mathrm{B}$ and $\mathrm{C}$ :}

The orientation and the internal rotation of areas $A$ and $B$ suggest that these two fold zones are conjugate and formed as a result of a space problem in the inner arc of the Kyrkosund fold. In this way they are similar to the conjugate shears often seen in the inner arc of buckle folds. The two conjugate zones presumably developed late in the bending process, essentially after the layerparallel shearing, as $S_{4 \mathrm{a}}$ surfaces become folded. The fold axes and the $L_{4}$ stretching lineation within areas $A$ and $B$ parallel $L_{4}$ in the surrounding terrain. The two conjugate zones have a line of intersection in about $320^{\circ} / 25^{\circ}$, parallel to $L_{4}$. This orientation is further evidence for a late $D_{4 a}$ development as the line of intersection is unrelated to the axis of the Kyrkosund fold, but is related to the late $\mathrm{D}_{4 \mathrm{a}}$ stretching direction.

The internal rotation involved in the formation of the folds in area $\mathrm{C}$ is clockwise around $\mathrm{L}_{4}$ - The sense of rotation, the orientation of the area and the subvertical NW-SE trending axial surface suggest, that area $C$ is comparable to area $A$ and belongs to the conjugate fold system. The minor ductile sinistral shears of area $C$ do not fit with the clockwise sense of the internal rotation. Presumably they formed at a very late stage of the bending, where they allowed the northern limb of the Kyrkosund synform to advance slightly in a NW direction.

Ramsö: On Ramsö the intensity of Koster dykes is unusually low, and individual dykes are generally thicker than to the west. The results of $D_{4}$ deformation are seen in most of the metadolerites as sheared margins or boudinage/necking. The $\mathrm{D}_{4}$ deformation appears to be strongest in the $\mathrm{SE}$ part of Ramsö and nearby skerries. The general trend of the dykes is NNE-SSW, but in the southern part the trend has turned to a $\mathrm{N}-\mathrm{S}$ direction and the dip has changed from the normal 60 $75^{\circ} \mathrm{W}$ values to values below $50^{\circ} \mathrm{W}$ (see Fig. 13). This pattern suggests the existence of a gentle $D_{4}$ antiform which dies out in a NW direction. 
The deformation in this antiform is best seen in SE Ramsö, where the thick, moderately dipping dykes become boudinaged, develop a hornblende lineation in the necked region of the dykes, and show sheared margins and gentle small folds. Thin dykes may be heavily sheared and may have developed syn- $\mathrm{D}_{4}$ garnets. Close to dyke contacts the gneiss layers show a faint foliation parallel to the contact, and locally the gneiss has been sheared so intensely by layer-parallel shearing, that it is mylonitic. $\mathrm{D}_{4}$ lineation and gentle folds are also seen. The coincidence between the NWplunging $\mathrm{D}_{4}$ fold axis and the boudin axes indicates, that the boudins were formed by layer-parallel stretching associated with the folding.

\section{The shear zone on Ramsholmen:}

The NNE-SSW trending ductile shear zone of Ramsholmen (Fig. 20) is the most important of the minor $\mathrm{D}_{4}$ shear zones, having the largest shear strain. Unfortunately it is only actually seen in very few exposures close to the shore of

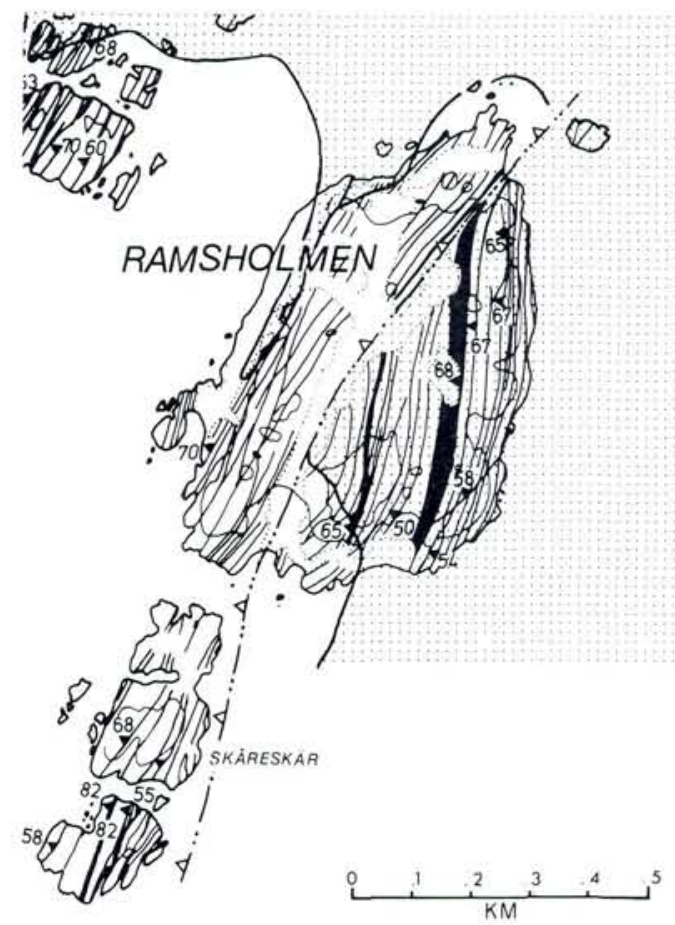

Fig. 20. Map of Ramsholmen. Dotted area indicates the extent of the Stora Le Marstrand gneisses.

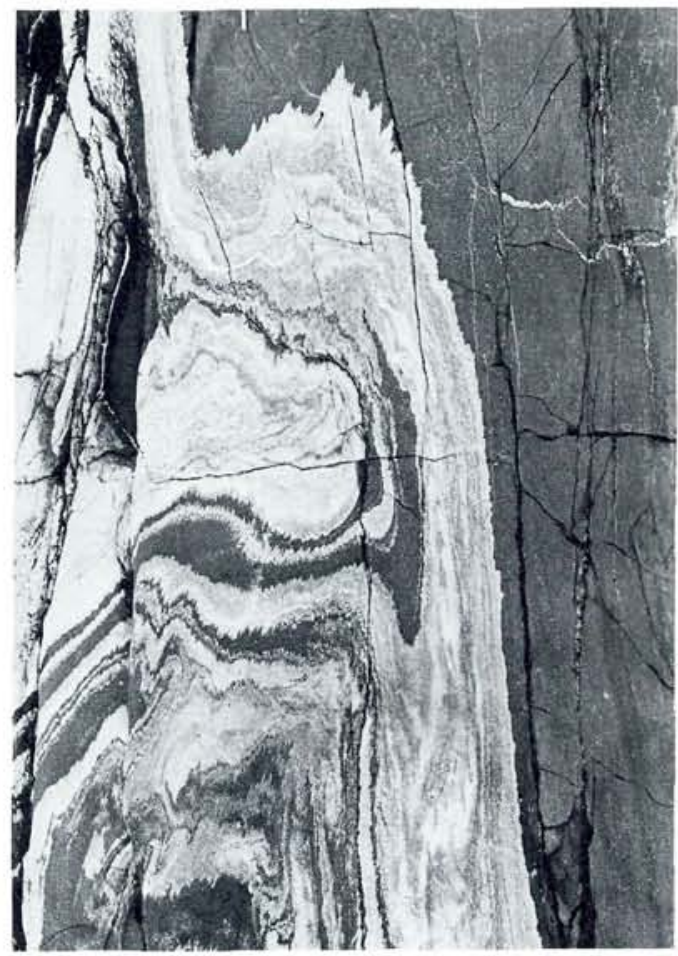

Fig. 21. Interference between $D_{3}$ and $D_{4}$ folds in a net-veined intrusion (Skåreskör).

northern Ramsholmen. The shear zone can be traced to the SE part of Skåreskär, where $D_{3}$ folds in a net-veined composite intrusion become refolded by $\mathrm{D}_{4}$ folds with axial surface $24^{\circ} / 60^{\circ} \mathrm{NW}$ (Fig. 21). These folds are presumably related to the nearby shear zone. The existence of the ductile shear zone on Ramsholmen is demonstrated by the discordance between the dykes of western and eastern Ramsholmen, by the reorientation of the Koster dykes of E Ramsholmen close to the shear zone and by the dextral displacement of the boundary between the Stora Le Marstrand gneisses and the genissified Tjällskär granite (Fig. 20). The horizontal dextral displacement is at least $500 \mathrm{~m}$ and possibly $700 \mathrm{~m}$.

The Kyrkosund synform presumably existed at the time of ductile shearing. If the N-S-trending layers of $\mathrm{E}$ Ramsholmen are moved to a position 500-700 $\mathrm{m} \mathrm{NE}$ of Ramsholmen, the N-S trend will fit the trend seen in the hinge of the Kyrkosund synform. Because of this fit, it is believed, that the shear deformation has a large component of dextral subhorizontal movement. 
The few exposures on northern Ramsholmen give too little information on the shear zone itself for a structural analysis. The width of the zone is about $10-20 \mathrm{~m}$. In the exposures it can be seen that the Stora Le Marstrand gneisses become sheared into a fine-grained, thinly banded, mylonitic gneiss. The planar fabric in this rock indicates that the shear zone is oriented $30^{\circ} / 50^{\circ} \mathrm{NW}$ in $\mathrm{N}$ Ramsholmen. Up to the shear zone the metadoleritic Koster dykes become thinned, foliated and lineated, and rotated towards parallelism with the shear zone.

\section{The fabric and the $\mathrm{D}_{4 \mathrm{~b}}$ structural relations in the layers}

Although the layers in the northern limb of the Kyrosund synform have been rotated and exposed to shearing, folding and boudinage as result of inhomogenous deformation, the bulk deformation of these layers has a very high component of homogeneous strain. The tabular layers in the pre- $\mathrm{D}_{4}$ sandwich are still largely tabular layers.

As shown below, the northern limb came into its present position during the $\mathrm{D}_{4 \mathrm{a}}$ stage and from late in $\mathrm{D}_{4 \mathrm{a}}$ to late in $\mathrm{D}_{4 \mathrm{~b}}$, when necking, boudinage and gentle folding took place, no structures resulting from inhomogeneous deformation have been recognized. During this period the deformation of the sandwich was homogeneous, but some minor elements within the layers underwent inhomogeneous deformation. These elements can be regarded as passive in relation to the total rock mass, but the structures and tectonite fabric of some of them are highly important in the understanding of the homogenous deformation.

\section{The tectonic fabric}

The tectonic fabric in homogeneously deformed layers consisting of rocks that had an isotropic fabric prior to the deformation, can give information on the shape of the strain ellipsoid, as these rocks will develop an anisotropy reflecting the type of deformation. The axes of the fabric $(x>y>z)$ will be directly related to the strain axes (Flinn 1965).
In the multilayered sandwich three types of layers can be considered as virtually isotropic prior to $\mathrm{D}_{4}$. The first of these are the Koster dyke layers, which had a completely isotropic pre- $\mathrm{D}_{4}$ fabric (doleritic). The second type comprises the tonalitic layers. In sector II the tonalite can be seen to be a massive plutonite with a foliated fabric along the marginal part of the body. In the centre the fabric is isotropic or there is a very slight foliation defined by parallel arrangement of the biotite grains. Elongation of quartz and feldspars is negligible. The third type of originally isotropic layer consists of rocks belonging to the original sheeted granite (Fig. 10), which unfortunately is only seen in sector III, where the $\mathrm{D}_{4}$ fabric is very pronounced. The rocks have been carefully examined for signs of an older directional fabric. The sheeted granite consisted originally of a porphyritic granite cut by sheets of an even-grained granite. Both rocks were transformed to gneisses without any evidence of an older deformational fabric. A relic compositional layering with $\mathrm{dm}$-wide mafic layers is sometimes seen in what was originally porphyritic granite (now augen gneiss).

The fabric of the Koster dyke layers is a typical L-fabric (Flinn 1965) with a very pronounced lineation (fabric $\mathrm{x}$ direction) formed by stretching and recrystallisation of the primary plagioclase grains. This aggregate lineation is paralleled by a mineral lineation defined by hornblende nematoblasts. The small cigar-shaped palgioclase aggregates may also define a less pronounced planar S-fabric (xy plane of the fabric) due to parallel orientation of the intermediate axis of slightly flattened cigars. Towards the margins of the dyke layers it is often seen that the size of the plagioclase aggregates and the hornblende nematoblast decreases, reflecting mimetic chilled margins. Very close to the margin a planar fabric is defined by mica flakes parallel to the contact. The thin, ductile dyke layers always have a pronounced planar fabric parallel or oblique to the layer boundary, but this fabric is related to the $\mathrm{D}_{4 \mathrm{a}}$ layer-parallel shearing connected to the flexural slip folding. Inhomogeneities in the dyke layers such as plagioclase phenocrysts, xenoliths and pre- $\mathrm{D}_{4}$ leucocratic veins are strongly stretched to parallelism with the cigar-shaped plagioclase aggregates.

The fabric in the plutonites is similar to that in 

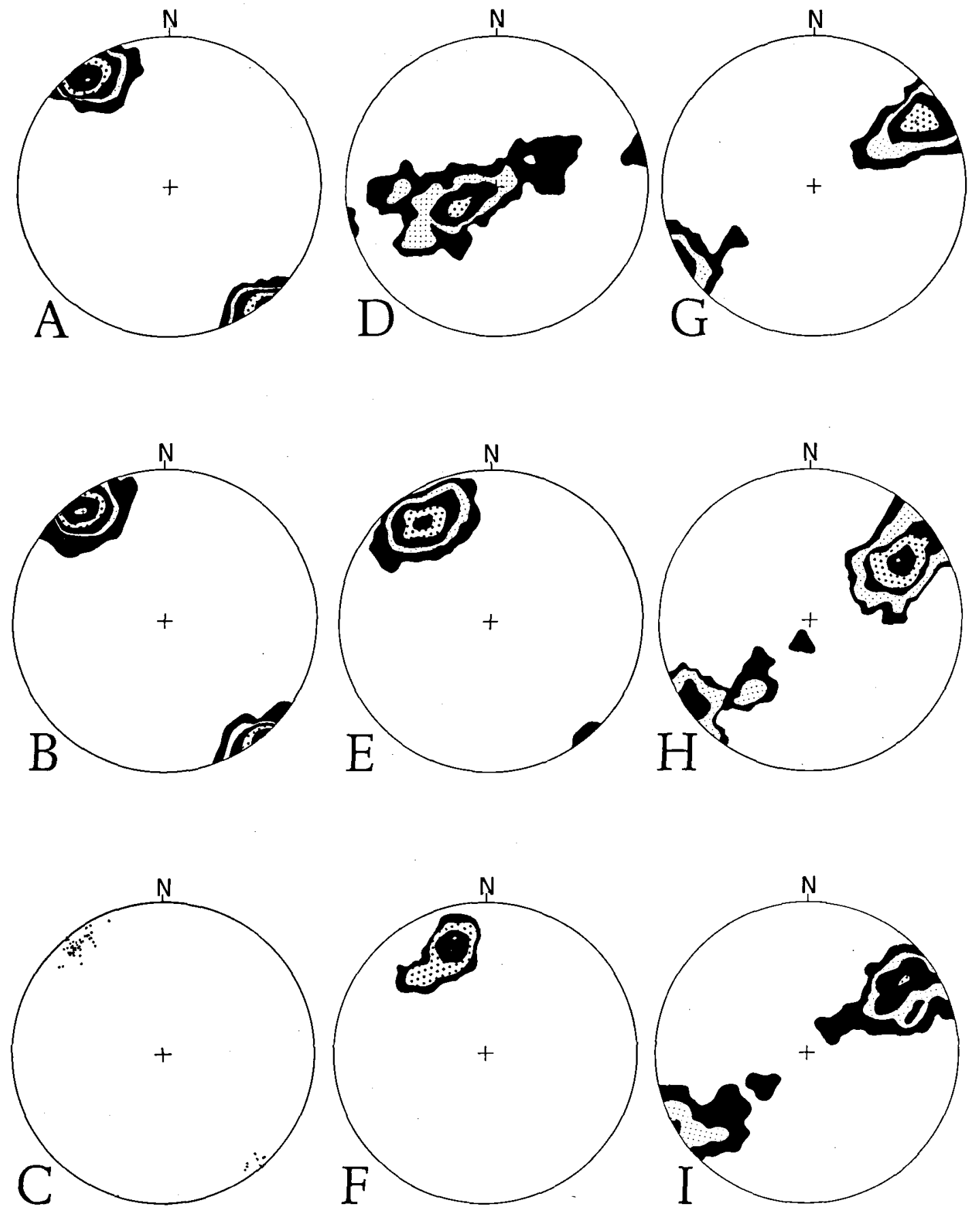

Fig. 22. Stereographic projection (lower hemisphere) of structural elements from sector III. A: stretching lineations in Koster dyke layers of subsector IIIC, contours at 1,5,10,20,30 and 50\% per $1 \%$ area, $\mathrm{N}=59$. B: All stretching lineations in subsector IIIC, contours at $1,5,10,20,30$ and $50 \%$ per $1 \%$ area. C: Fold axes from gneiss layers in subsector IIIC. D: Boudin axes measured on Ramnefjäll pegmatites in subsector IIIB, C, contours at $1,5,10$ and $20 \%$ per $1 \%$ area, $\mathrm{N}=50$. E: Stretching lineations in subsector IIIB, contours at $1,5,10,20$ and $30 \%$ per $1 \%$ area, $N=112$. F: Stretching lineations in subsector IIIA, contours at $5,10,20$ and $30 \%$ per $1 \%$ area, $\mathrm{N}=36$. G: Poles to sandwich layers in subsector IIIC, contours at $1,5,10$ and $20 \%$ per $1 \%$ area, $N=62$. $\mathrm{H}$ : Poles to foliation in gneiss layers of subsector IIIC, contours at $1,2,6,10,20$ and $30 \%$ per $1 \%$ area, $N=71$. I: Poles to axial surfaces of folded Ramnefjäll pegmatites in subsector IIIC, contours at $1,5,10$ and $20 \%$ per $1 \%$ area, $N=48$. 
the Koster dykes. The pronounced L-fabric is defined by cigar-shaped quartz and feldspar aggregates and by elongated clusters of biotite. A hornblende mineral lineation may parallel the aggregate lineation in the tonalitic layers. An S-fabric component may also be developed in the plutonites, but it is always weak. When present it is defined by the intermediate axes of the cigarshaped aggregates and a parallel orientation of the biotite flakes. The strike of the S-fabric component is parallel to the layers and the dip is about $70^{\circ}$ to the west, but generally it is difficult to measure properly. Inclusions and phenocrysts in the original igneous granitoids are elongated parallel to the longest axis of the aggregate lineation, suggesting strong stretching in this direction.

The orientation of the stretching direction (fabric $\mathrm{x}$-direction) in the gneiss layers is parallel to that in the Koster dyke layers. The distribution of the stretching directions measured in subsector IIIA, B and C are shown in Fig. 22. From this figure it can be seen that the distributions are strongly concentrated, and that the stretching has the same direction of plunge in all three subsectors. The angle of plunge decreases from a moderate value in subsector IIIA to subhorizontal in subsector IIIC. The distribution of $x$-directions deviates slightly in subsector IIIA, but this is primarily due to a smaller amount of measurements and a weak flexuring of the lineation as seen from Fig. 24.

The strong stretching parallel to the fabric $\mathrm{x}$-direction is also seen in homogeneously deformed heterogeneities of the gneiss layers as demonstrated by the examples of Fig. 23. When the fabric of the homogeneously deformed layers with an isotropic pre- $D_{4}$ fabric is related to the shape of the strain ellipsoid, it is obvious, that the shape of the ellipsoid is that of cigar with $X>>Y Z$. This means that the $D_{4}$ stretching event was almost pure constriction, with the strain $\mathrm{X}$-axis subhorizontal and parallel to the fabric $\mathrm{x}$-direction.

\section{The regional orientation of the fabric $\mathrm{x}$-direction}

On the basis of the measured orientations of the stretching lineation the maps Fig. 24 and 25 were constructed. In Fig. 24 the trends of the stretch- ing lineations are shown and, as seen, the trends are almost straight and parallel with only a few local gentle bents such as that mentioned for subsector IIIA. The straight, parallel trend of the lineation indicates that the direction of the stretching was constant and that essentially no rotation of the northern limb has taken place around the axis of the Kyrkosund synform (303\% $66^{\circ}$ ) after the formation of the linear fabric. The northern limb had then reached its present position when the linear fabric began to develop. From the map it is also seen the direction of the stretching lineation forms an angle with the dyke trend. This angle decreases progressively towards NE with increasing strain, and in subsector IIIC it is negligible.

Fig. 25 shows the regional variation in the plunge of the stretching lineation. The map shows the mean plunge $/ 0.5 \mathrm{~km}^{2}$, and it has been constructed in the same way as the map Fig. 13 (see p. 165). The plunge decreases regularly across the northern limb of the Kyrosund synform and becomes subhorizontal in subsector IIIC. It is obvious that when the layers enter sector III, they develop a stretching lineation, which becomes progressively more and more flat-lying passing from subsector IIIA to IIIC. When the layers enter sector III the stretching lineation is developed first in the dyke layers.

The rotation of the stretching lineation towards horizontal with increasing strain is taken as evidence of a rotation of the main stretching direction during $D_{4}$. The initial development of the stretching fabric took place late in the $\mathrm{D}_{4 \mathrm{a}}$ stage, when the northern limb was rotated into its present position. At this stage the initial stretching produced the moderately plunging stretching fabric. The further progress of the stretching event the $D_{4 b}$ stage - affected with increasing intensity sectors IIIA, B, C and D, and the initially plunging stretching fabric rotating towards the new subhorizontal position of the $\mathrm{D}_{4 b}$ stretching direction.

\section{The internal structures of the layers and their relations to the $\mathrm{D}_{4 \mathrm{~b}}$ deformation of the sandwich}

The minor structures in the gneiss layers have been studied especially in the most highly 
A
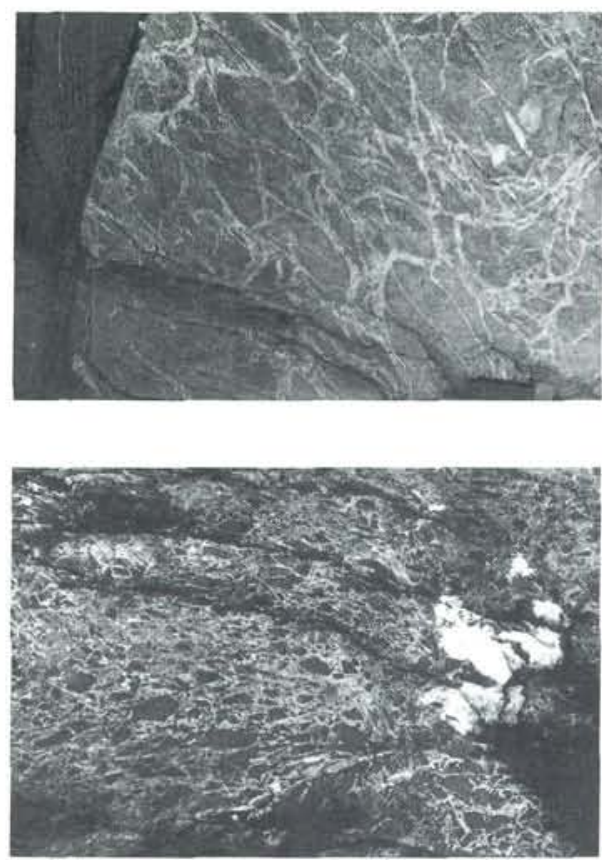

B

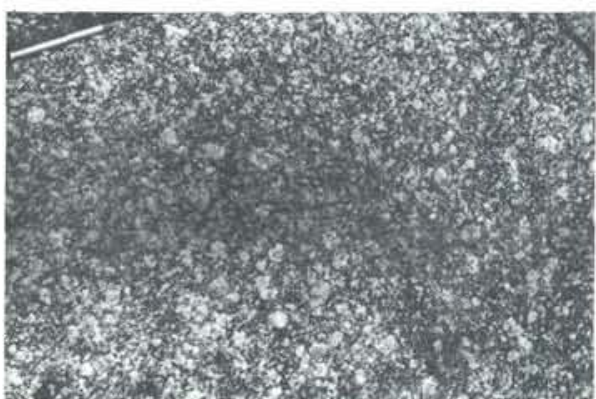

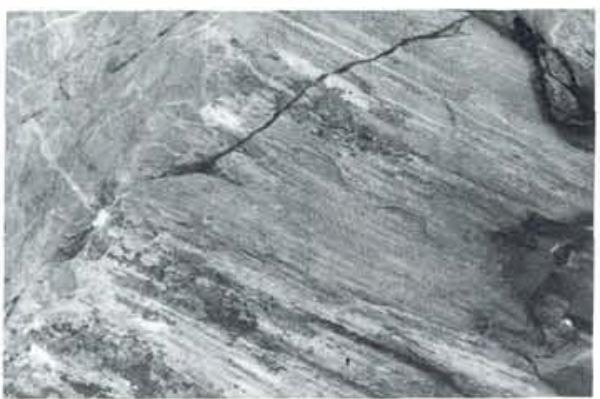
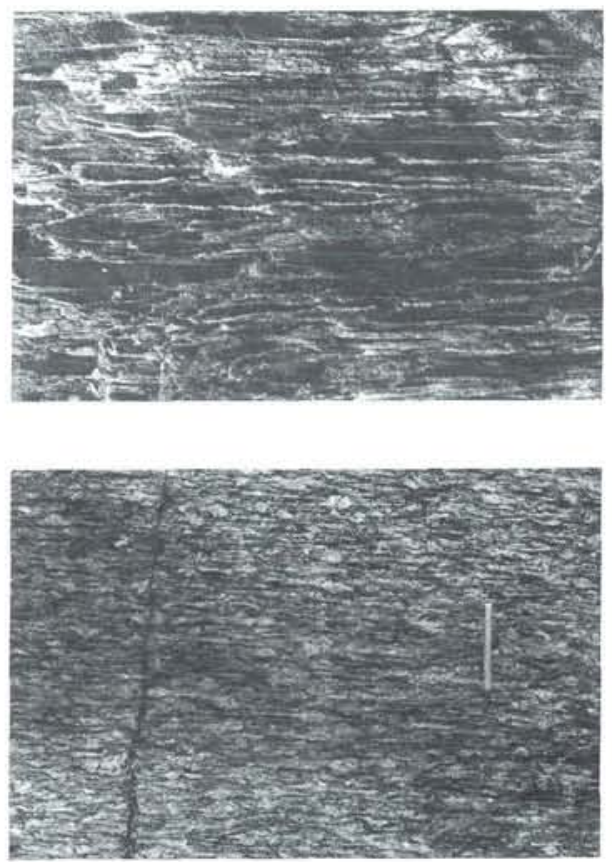

Fig. 23. Constriction fabrics in the gneiss layers seen parallel and normal to the stretching direction. A: migmatic Stora Le Marstrand gneiss. B: Agmatite. C: Augen gneiss belonging to the sheeted granite.

strained part of sector III and especially in subsectors IIIB and C. In subsector IIID, the structural situation is more complex due to the $\mathrm{D}_{4 \mathrm{c}}$ and $\mathrm{D}_{\text {td }}$ events.

Among the most useful elements in the gneiss layers are the Ramnefjäll pegmatites, because these are known to have had a considerably greater variation in orientation prior to $\mathrm{D}_{4}$ than the pre- $\mathrm{D}_{4}$ sandwich layers. As the initial orientation of fold axes, axial surfaces and boudin axes developed by deformation of competent layers depends on the orientation of the layers to be deformed (Ramberg 1955, 1959, Biot 1961), a great variation in the initial orientation of those ele- ments should be expected in the case of Ramnefjäll pegmatites. When formed, the planar and linear elements (except for those normal to X) will rotate towards parallelism with the strain $\mathrm{X}$ direction, while the poles of planar structures will move towards the $\mathrm{Z}$ direction if $\mathrm{Y}>\mathrm{Z}$.

In the high strain belt the Ramnefjäll pegmatites have a trend subparallel to the sandwich layers on horizontal surface (Fig. 31), but in sections normal to the stretching direction a consideral variation is seen. The pegmatites have been deformed by folding as well as by boudinage, and they have always reacted as a competent material. An L-S fabric of the kind already described 


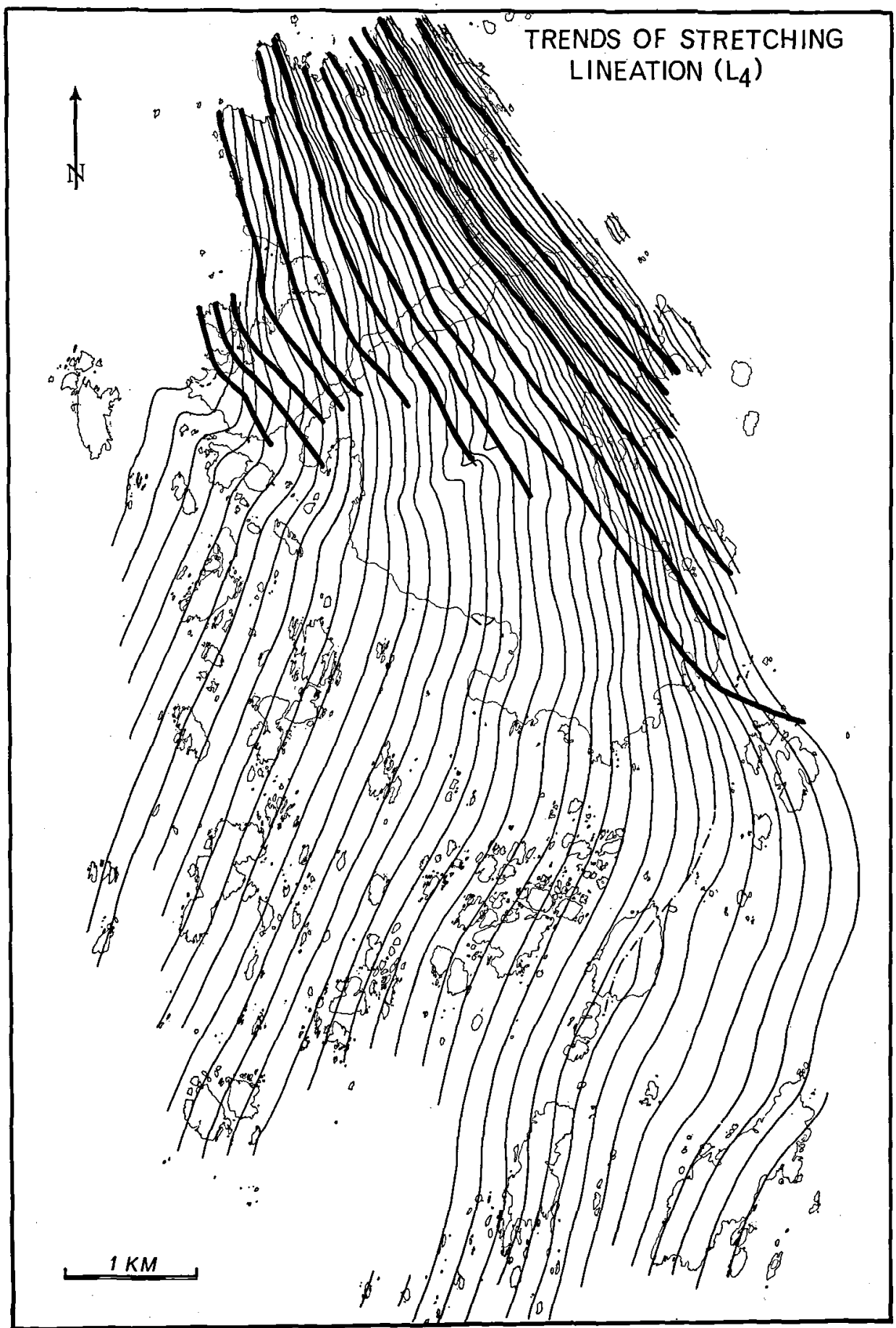

Fig. 24. Trends of stretching lineation $\left(L_{4}\right)$.

from the dykes and gneiss layers is also developed in the Ramnefjall pegmatites. The boudinage of the Ramnefjäll pegmatites occurred late during $D_{4 b}$ and the lineation $\left(L_{4}\right)$ is disrupted/bent by the boudinage/necking. The measurements of fold axes, axial surfaces and boudin axes in the 


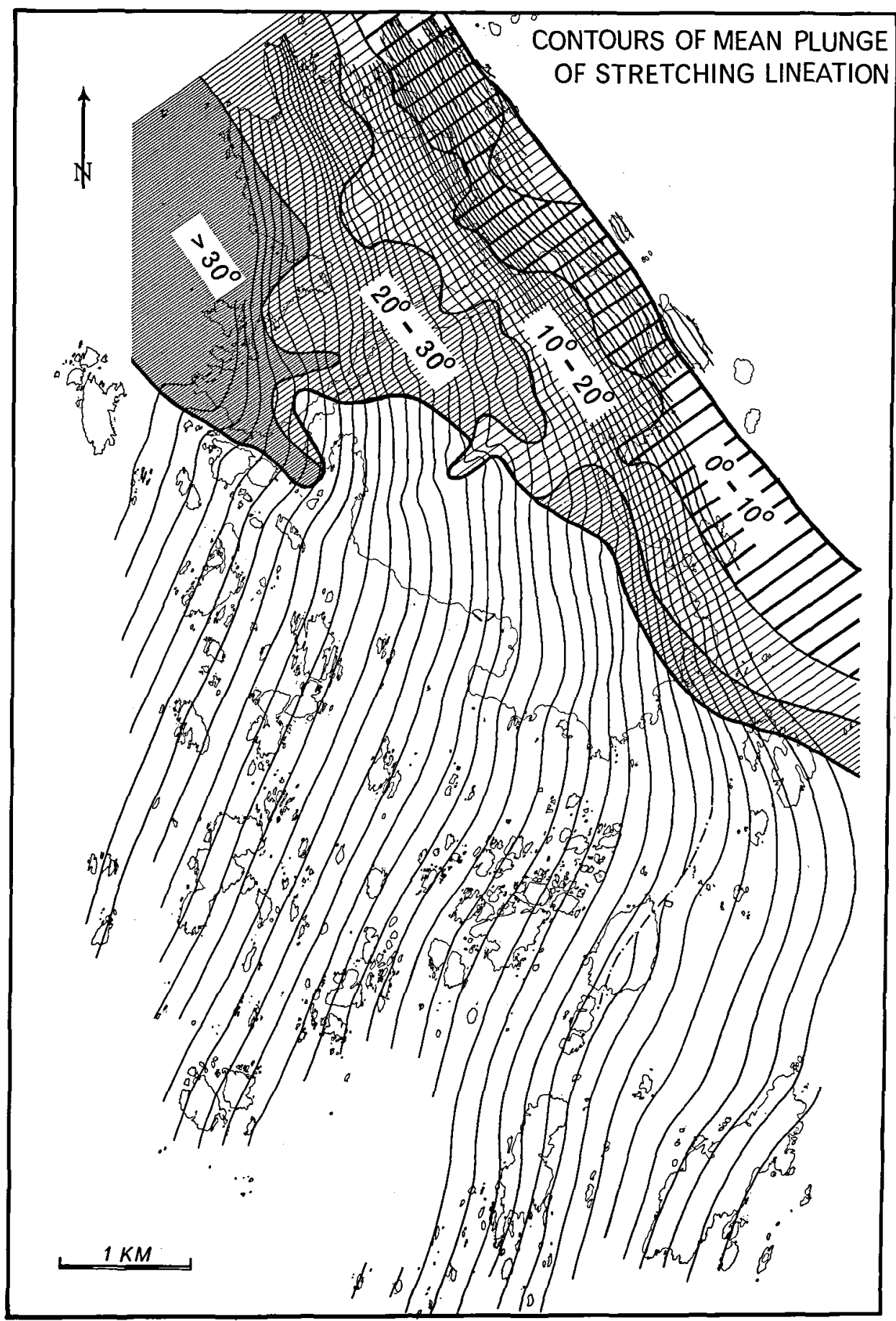

Fig. 25. Contours of mean plunge of stretching lineation $\left(\mathbf{L}_{4}\right)$.

deformed Ramnefjäll pegmatites are shown in Fig. 22.

The minor folds in the gneiss layers (excluding folds shown by the Ramnefjäll pegmatites) all have fold axes and axial surfaces parallel to the stretching direction. The dip of the axial surfaces 

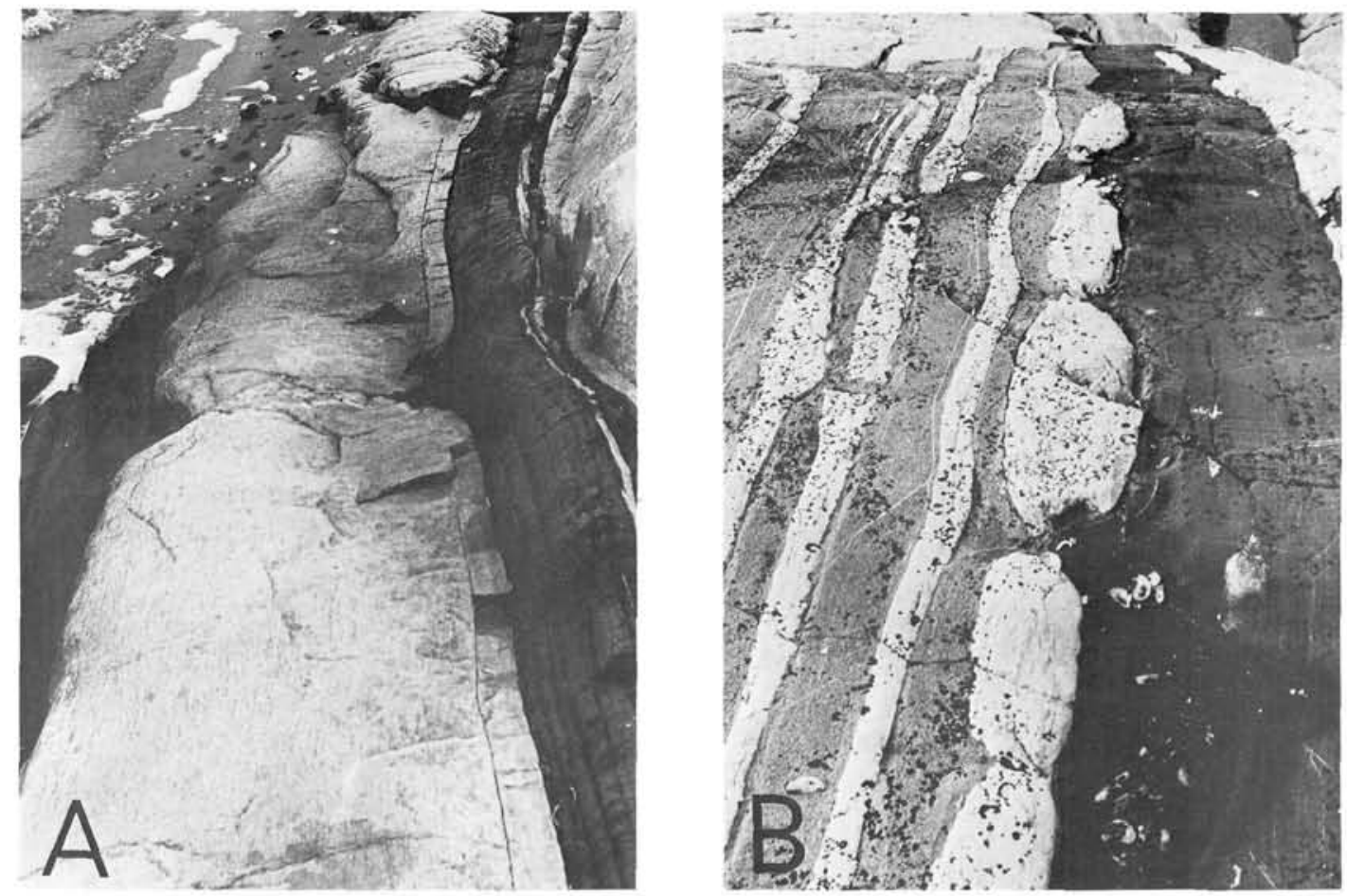

Fig. 26. A: Late $D_{44}$ boudinage of a gneiss layer between two Koster dykes. B: Boudinage of Ramnefjäll pegmatite. The boudinaged Ramnefjall pegmatite is the western part of a thicker pegmatite cut by a Koster dyke. The age relations are seen in the top of the picture, where a xenolith of the pegmatite occurs in the Koster dyke. In both of the figures the Koster dykes have reacted incompetently.

shows a variation from a steep dip to NE to a steep dip to the SW. As it was observed that this variation is no greater than the variation of the pre- $\mathrm{D}_{4}$ foliation, only a few axial surfaces were measured, because planar elements showing a larger dip variation, such as the axial surfaces of folds shown by the Ramnefjäll pegmatites, are more important in the description of the geometry of the deformation. No axial surface foliation is developed in the folds within the gneiss layers.

The main problem with the folds in the gneiss layers is that one generally cannot separate $\mathrm{D}_{4}$ folds from older folds. The folds shown by folding of the foliation, migmatitic veins and compositional banding in the gneisses are of the same style as the very common $\mathrm{D}_{2}$-folds in the sector $\mathrm{I}$, but only in a few cases, as for example when the Koster dykes cut a regular coherent earlier fold pattern, can any folds be demonstrated to be original $\mathrm{D}_{2}$ folds. In a few cases the pre- $\mathrm{D}_{4}$ folds are stretched into tubular structures. The fold axes plotted in Fig. 22 are thus of uncertain age, but at least some, if not all, are of $\mathrm{D}_{2}$ age.
The sandwich layers as well as minor elements within the gneiss layers show boudinage/necking structures (Fig. 26) with axes normal to the stretching direction. Thus the "central vents" and dykes "which may swell into real stocks" described by Asklund (1950) are no more than boudins and necks of thick Koster dykes (see the NE corner of Fig. 18).

In all cases the boudinage occurred late in $\mathrm{D}_{4 \mathrm{~b}}$ and the formation of the stretching fabric must be related to a soft and uniform reaction of the rock mass to the main phase of stretching. Usually the boudins are closely spaced, indicating only a minor amount of late $D_{4 b}$ stretching. Only a few boudin axes have been measured on boudins formed by the sandwich layers. The orientation of these fit with the distribution of the boudin axes measured on the Ramnefjäll pegmatites (Fig. 22 ), but the boudins of the sandwich layers show a lower plunge variation as they are controlled by the dip of the sandwich layers.

From the stereographic projections of the different structural elements it is seen that: 1) the 
fold axes of the Ramnefjäll pegmatites and all other fold axes measured in subsector IIIC parallel the stretching lineation (the strain $\mathrm{X}$-axis); 2) the boudin axes as well as the poles to the axial surfaces of the folded Ramnefjall pegmatites lie in a plane normal to the stretching direction; this plane also contains the poles to the pre- $\mathrm{D}_{4}$ foliation, the poles to all other axial surfaces of folds in the gneiss layers, and the poles to the sandwich layers.

The bending in the Kyrkosund synform $\left(D_{4 a}\right)$ rotated the pre-existing structures around the $303 \% 66^{\circ}$ fold axis, but the original angular relations between the sandwich layers and the older structural elements would have been left intact in the competent layers, if they had not been stretched.

As the stretching lineation defines the $\mathrm{X}$-axis of the strain ellipsoid, the YZ-plane of the ellipsoid will be the plane defined by the poles to the planar elements and the boudin axes. In this plane there is a large spread of the poles as well as of boudin axes, which indicates, that there cannot be a large difference in the length of the $Y$

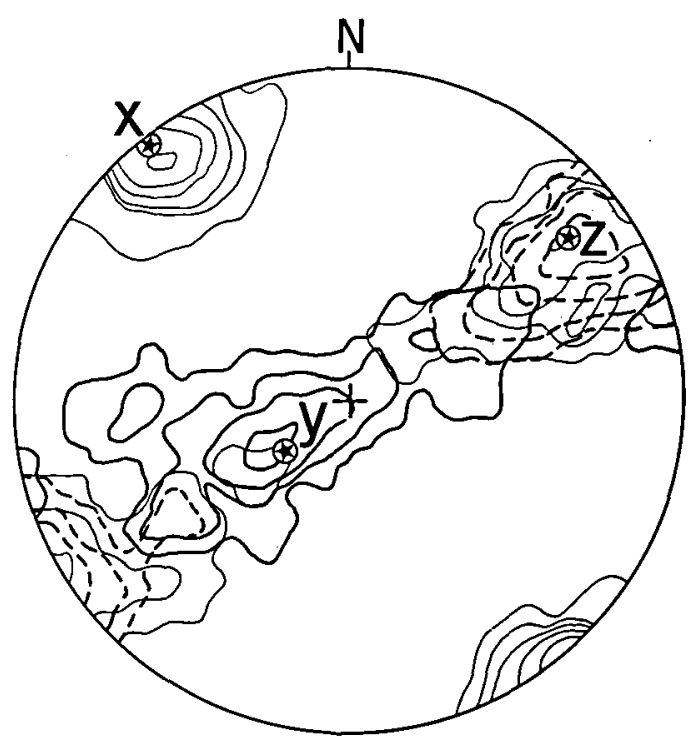

Fig. 27. Orientation of the strain axes seen in relation to the contours of the stretching lineations (Fig. 22B), boudin axes (Fig. 22D), poles to the sandwich layers (Fig. 22G) and the poles to the axial surfaces of folds formed on the Ramnefjäll pegmatites (Fig. 22I). In the NE-SW girdle heavy lines show contours of boudin axes, dashed lines show contours of poles to the sandwich layers, while thin lines indicate contours of poles to axial surfaces. and $\mathrm{Z}$ axes of the strain ellipsoid. A complete random distribution in the YZ-plane is not to be expected even if $Y=Z$, because none of the elements that spread in the YZ-plane had a random orientation prior to the stretching event.

The investigations on the tectonite fabric, the minor elements and the sandwich rock mass thus suggest that the northern limb of the Kyrkosund synform became exposed to strong homogeneous deformation resulting in an almost pure constriction in the rock mass. In the strongest $D_{4 b}$ stretched belt the strain ellipsoid has a horizontal NW-SE trending X-direction subparallel to the trends of the layers. The cigar-shaped strain ellipsoid appears to be very slightly oblate with the $\mathrm{XY}$ plane dipping about $65^{\circ} \mathrm{SW}$. The orientation of the strain axes is shown in Fig. 27. The position of the $\mathrm{Z}$ axis is defined by the strongest concentration of the poles to the sandwich layers, pre- $\mathrm{D}_{4}$ foliation and the axial surfaces, and it has the orientation of $56^{\circ} / 25^{\circ}$. The $\mathrm{Y}$ axis will then have the orientation $236 \% 65^{\circ}$, which is within the strongest concentration of the boudin axes and in accordance with the planar S-fabric found to have a dip of about $70^{\circ} \mathrm{SW}$.

\section{The $\mathrm{D}_{4 \mathrm{c}}$ and the $\mathrm{D}_{4 \mathrm{~d}}$ events}

The late $D_{4}$ structures $\left(D_{4 c}\right.$ and $\left.D_{4 d}\right)$ are seen mainly in subsector IIID where they are frequent. Subsector IIID is poorly exposed and the outcrops are restricted to about ten small islands of which Hamneholmen, Brattskär and Rönningerna are the most important. The bulk finite fabric of this subsector, in contrast to the rest of sector III, has a pronounced planar fabric component which is subvertical and parallel to the layers of the sandwich. The $D_{4 c}$ and older structures have been adjusted to this plane, and it appears, that $D_{4 c}$ had the character of a flattening resulting in shortening across this subsector. The steep layered structure of the rock mass is defined by gneiss layers of different composition, by layers of Ramnefjäll pegmatites and by amphibolitic layers. It is difficult to distinguish between thin Koster dyke layers and layers of older amphibolite, but Koster dykes ar known to occur here.

The $\mathrm{D}_{4 \mathrm{c}}$ event resulted not only in a planar fabric but also in folding and minor ductile shearing. 

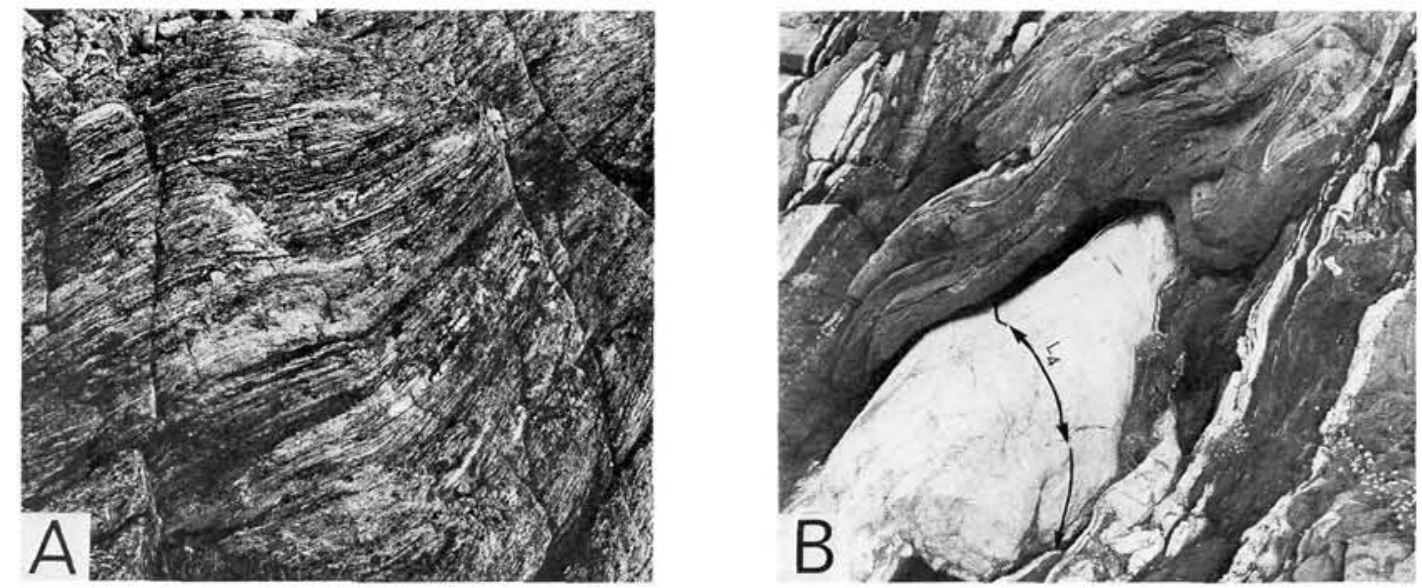

Fig. 28. A: $\mathrm{D}_{4 c}$ folded stretching lineation in a gneiss layer (subsector IIIC). B: folded stretching lineation in Ramnefjäll pegmatite.

The $\mathrm{D}_{4 \mathrm{c}}$ folds are recognized in subsector IIID as mesoscopic, close to isoclinal folds which refold $\mathrm{L}_{4}$ (see Fig. 28). Their axial surfaces are upright or steeply inclined and strike NW-SE (Fig. 29A). The fold axes spread in the mean axial surface, but most plunge gently or moderately towards NW or SE- The orientation of the axial surfaces and the direction of the fold axes are thus the same as for the $D_{4 b}$ orientation of similar elements, but the $\mathrm{D}_{4 c}$ plunge variation is different. Most of the folds have a Z-shaped asymmetry, but $\mathrm{S}$-shapes also occur. $\mathrm{D}_{4 \mathrm{c}}$ structures are seen in Fig. $30 \mathrm{~A}$ and $\mathrm{B}$.

A non-penetrative axial surface foliation $\left(\mathrm{S}_{4 c}\right)$, often in the form of a crenulation cleavage, can occur in incompetent layers such as the $\mathrm{S}_{4 \mathrm{a}}$ foliated dykes and thinly banded, mica-rich Stora Le Marstrand gneisses. In unfolded dykes and gneiss layers evidence of minor $\mathrm{D}_{4 \mathrm{c}}$ layer-parallel shearing is seen in the development of a crenulation cleavage (foliation) oblique to the trend of the layers and of small-scale asymmetric folds at the
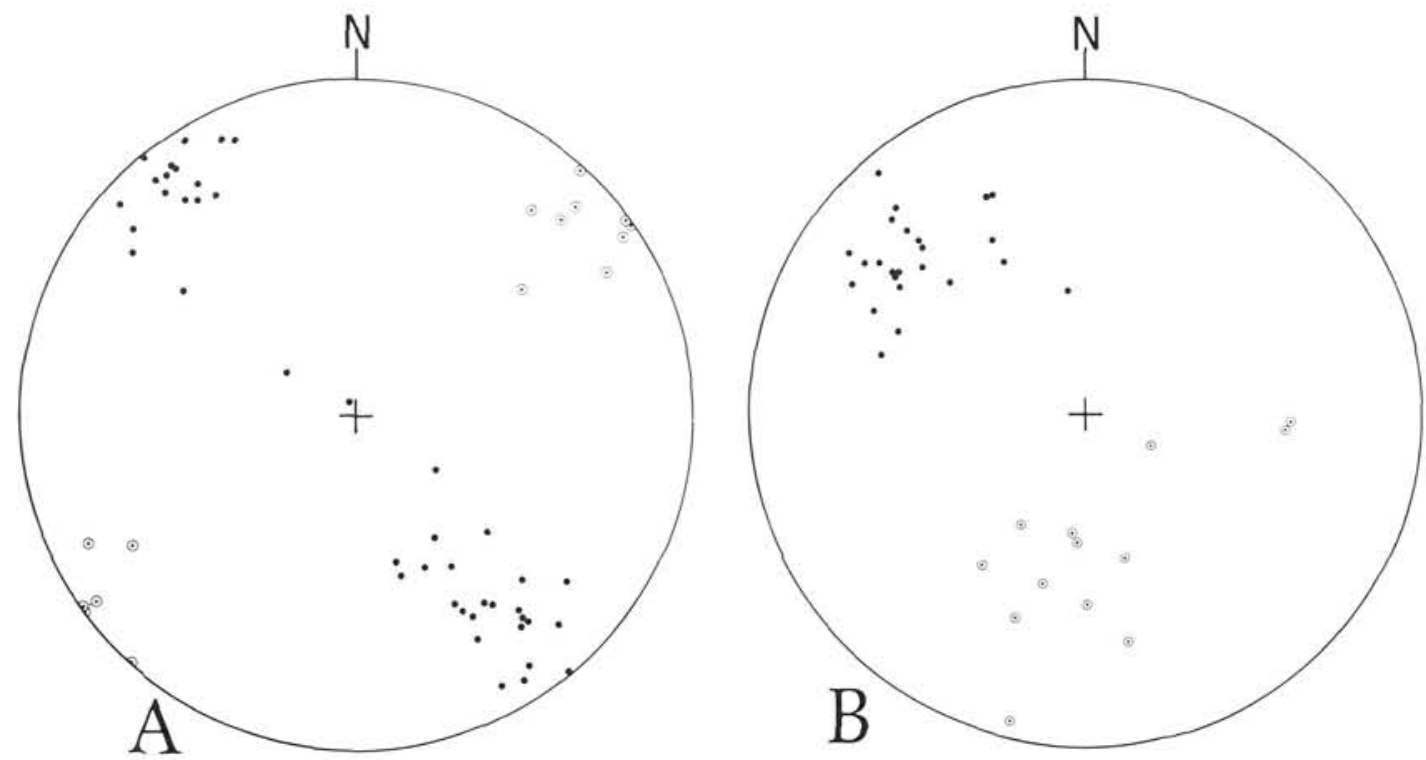

Fig. 29. Fold axes (dots) and poles to axial surfaces (circles) of $D_{4 c}$ folds (A) and $D_{4 d}$ folds (B). 

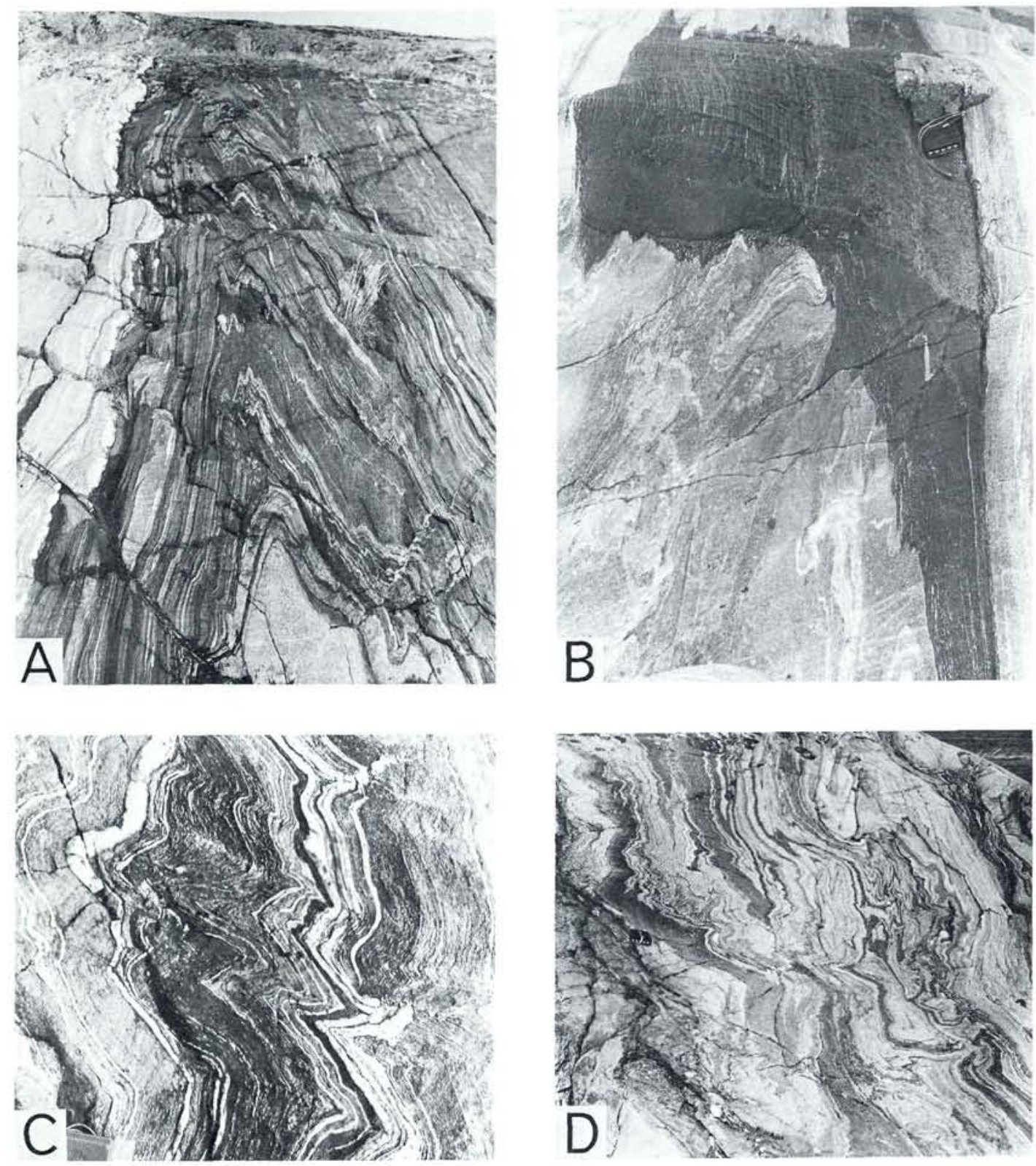

Fig. 30. A: $D_{4 c}$ fold in amphibolite banded Stora Le Marstrand gneiss. B: $D_{4 c}$ folded Koster dyke. In the discordant dyke the $S_{4 a}$ foliation is $D_{t c}$ folded and axial surface foliation $S_{4 c}$ is developed. C: $D_{4 d}$ folds. $D$ : Interference between $D_{k c}$ and $D_{t d}$ folds. The $D_{k c}$ fold are mainly closing upward and downwards in the figure, while the $D_{4 d}$ folds have subhorizontal axial surfaces.

contacts of layers of different composition. These small folds plunge moderately towards NW and have a Z-shaped asymmetry compatible with a dextral sense of shearing. The oblique crenulation cleavage also indicates a dextral pattern of shearing. The intersections between the crenulation cleavage and the layer boundaries are paral- lel to the axes of the small asymmetric folds. Garnets have grown locally during this shearing.

Effects of $D_{t c}$ deformation can be seen here and there all over sector III, even though their frequency decreases towards the west. The $D_{4 c}$ folds are less compressed when seen outside subsector IIID. 
$D_{4 d}$ folds (Fig. 30C and D) occur only in the eastern part of subsector IIIC and in subsector IIID. They are seen on all scales and typically they have a $Z$-shaped asymmetry with the long limb parallel to the common trend of the sandwich. The axial surfaces are commonly moderately inclined to NNE while the fold axes plunge gently or moderately to NW (Fig. 29B). The megascopic folds are gentle and they are just visible on the map. The mesoscopic folds vary from gentle to open. Within well foliated gneiss and dyke layers a non-penetrative axial surface foliation of crenulation type may have developed.

The relations between the $D_{4 c}$ and the $D_{4 d}$ structures and the older $D_{4}$ structures are uncertain. Perhaps the $D_{4 c}$ and $D_{4 d}$ folds represent trains of conjugate folds of which the axial surfaces of the $D_{4 c}$ folds have been rotated towards the planar fabric.

\section{Strain calculations}

The constrictional strain in the northern limb of the Kyrkosund fold has been calculated for a belt situated in the west side of subsector IIIC in N Koster. The value obtained is a minimum value for the highly strained areas as the strain increases farther to the east. In the calculations the layers have been considered to be 1) homogeneously deformed, 2) deformed without volume changes, and 3) deformed by a pure constrictional deformation with a horizontal, layer-parallel strain X-axis. 1) and 2) will be discussed later while the instances of 3 ) are already discussed.

To study the amount of the strain in the highly deformed part of the northern limb of the Kyrkosund synform, a megalayer within the sandwich has been selected. This megalayer is shown in Fig. 6 and, as mentioned on p. 163, it contains the best defined master dykes. Two of these master dykes form the boundaries of the megalayer. As the strain ellipsoid in the northern part of the megalayer has the shape of a cigar with $\mathrm{Y}=\mathrm{Z}$ and a horizontal, layer-parallel $X$-axis, the bulk strain in the megalayer can be calculated. In the south where the sandwich is unaffected by $\mathrm{D}_{4}$, a spherical body with diameter equal to the thickness of the megalayer will have a volume of $4 / 3 \pi$ $\left(1 / 2 \mathrm{AA} \sin 65^{\circ}\right)^{3} \mathrm{~km}^{3}$, where AA'sin65 is the thickness of the megalayer dipping $65^{\circ} \mathrm{W}$. In the northern limb the thickness of the megalayer is reduced to BB'sin 75 (see Fig. 6) and the $Y$ and $Z$ axes of the ellipsoid will then have the length of $1 / 2 \mathrm{BB} \sin 75 \mathrm{~km}=0.246 \mathrm{~km}$. The length of the strain $\mathrm{X}$-axis can be calculated thus:

$4 / 3 \pi\left(1 / 2 \mathrm{AA}^{\prime} \sin 67^{\circ}\right)^{3} \mathrm{~km}^{3}=4 / 3 \pi\left(1 / 2 \mathrm{BB}{ }^{\prime} \sin 75^{\circ}\right)^{2}$ $\mathrm{X} \mathrm{km^{3 }}$

which gives a length of the $\mathrm{X}$-axis of $9.436 \mathrm{~km}$. If the properties of the sphere and the ellipsoid are reduced to a sphere and ellipsoid of unit volume, the length of the $\mathrm{X}$-axis is 7.07 while $\mathrm{Y}=\mathrm{Z}=$ 0.18 .

The strain ellipsoid is defined by the axes and the ratios $\mathrm{a}=\mathrm{X} / \mathrm{Y}$ and $\mathrm{b}=\mathrm{Y} / \mathrm{Z}$. In this case $\mathrm{a}=$ 39.3 and $b=1.0$. Usually the departure of the ellipsoid from a sphere is expressed by $k=(a-1) /$ (b-1), while the amount of deformation ( $r$ ) is given by $r=a+b-1$ (Flinn 1962). In the present case $\mathrm{k}=\infty$ and $\mathrm{r}=39.3$.

The original sphere has been stretched 11.4 times in the X-direction, while the shortening normal to the sandwich layers (and to the $\mathrm{X}$-direction) is by the factor 0.3 .

The value for the layer-parallel subhorizontal stretching obtained by this strain analysis can be checked on the Ramnefjäll pegmatites (Fig. 31). This swarm of pegmatites dykes is seen in the SW part of S Koster, where on horizontal surfaces they form an angle of $60^{\circ}$ to the Koster dykes. However, as this area is in sector II, this angle is not original. The pegmatites have been rotated by $D_{4 a}$ and a slight amount of stretching is also seen as the 'master Koster dykes' are brought a little closer together.

The situation in S Koster is shown in Fig 32B. In this figure the pegmatites form an angle of $60^{\circ}$ with the master dykes on a horizontal surface, while the master dykes are horizontally separated by a distance of $145 \mathrm{~m}$.

In the strongly horizontally stretched part of sector III the horizontal distance between the master dykes is reduced to $46 \mathrm{~m}$ measured along BB' of Fig. 6, but what angle will the Ramnefjäll pegmatites form with the master dykes in the horizontal plane? This angle can be obtained by deforming the parallelopiped from Fig. 32B by pure horizontal stretching. This deformation must reduce the horizontal distance between the master dykes from 145 to $46 \mathrm{~m}$, i.e. the paral- 


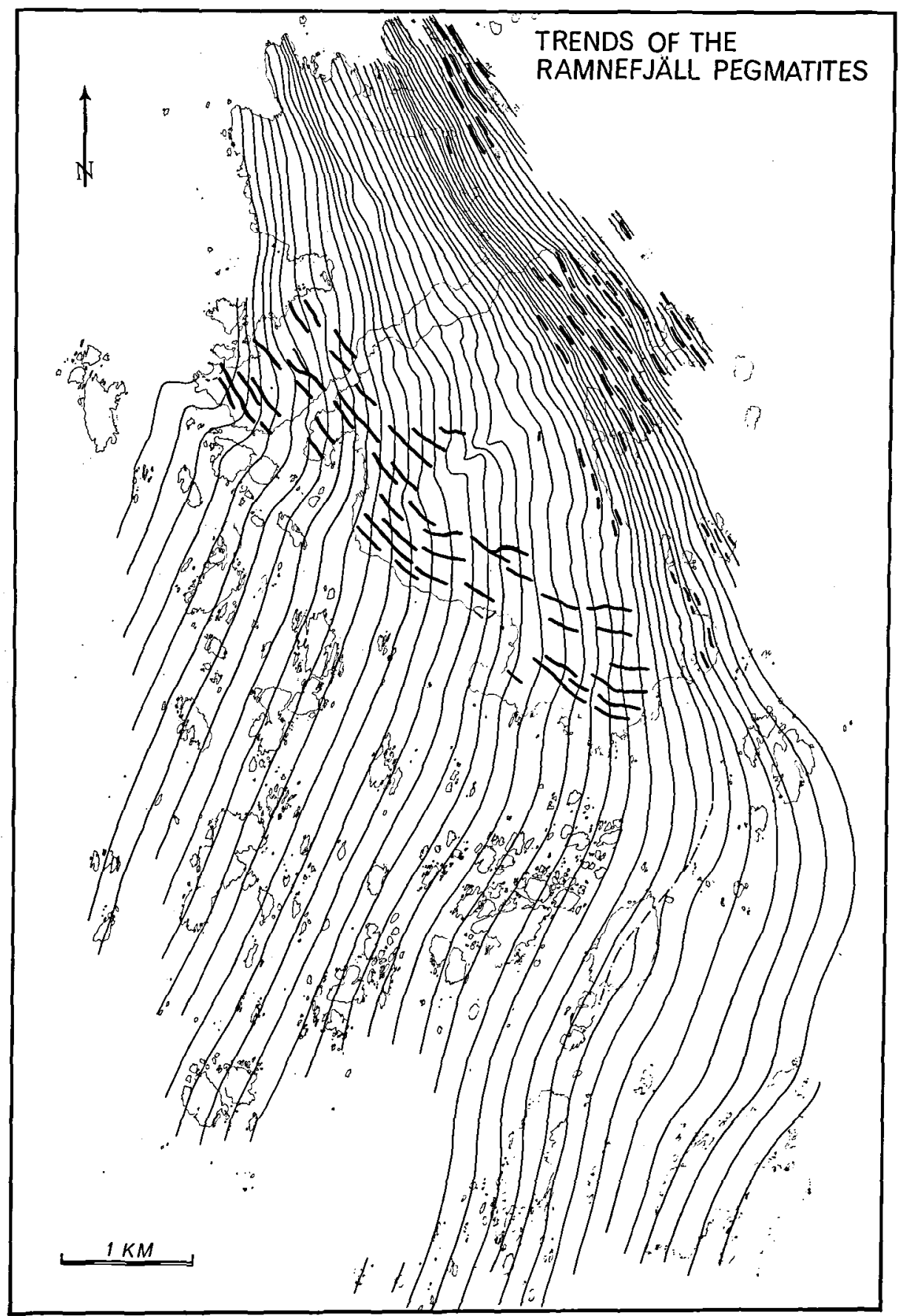

Fig. 31. Trends of the Ramnefjäll pegmatites.

lelopiped in Fig. 32B must be deformed to a new parallelopiped of the same volume (Fig. 32C), but with a horizontal distance between the master dykes of $46 \mathrm{~m}$. The dip of the master dykes are $70^{\circ} \mathrm{W}$ and $75^{\circ} \mathrm{W}$ in parallelopiped $\mathrm{B}$ and $\mathrm{C}$ respectively.

The volume of parallelopiped $B$ is given by $\mathrm{V}_{\mathrm{B}}=(145 \mathrm{~m})^{2} \sin 70^{\circ} \times 85 \mathrm{~m}$. As $\mathrm{Y}=\mathrm{Z}$ in the 
THE DEFORMATION OF THE

RAMNEFJÄLL PEGMATITES
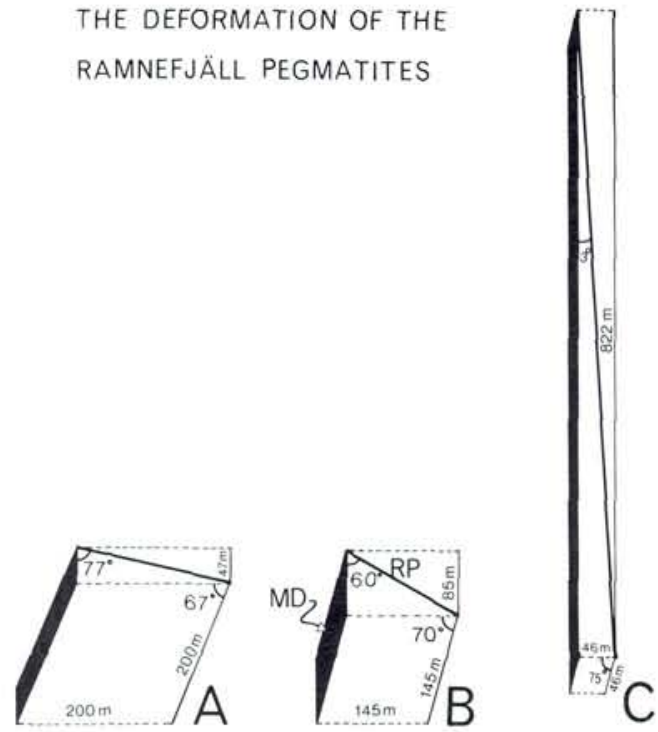

Fig. 32. The constriction deformation of the Ramnefjäll pegmatites. The units are bounded to the left and right by master dykes (MD). The trend of the Ramnefjall (RP) pegmatites is shown on the top surfaces. See text for explanation. constrictional strain ellipsoid, the volume of the stretched parallelopiped is $V_{C}=(46 \mathrm{~m})^{2} \sin 75^{\circ} \times$ $\mathrm{X} \mathrm{m}$ where $\mathrm{X}$ is the length of parallelopiped. Since $V_{C}$ is equal to $V_{B}, X=(145 \mathrm{~m})^{2} \sin 70^{\circ} \times$ $85 \mathrm{~m} /(46 \mathrm{~m})^{2} \sin 75^{\circ}=822 \mathrm{~m}$. When $X$ is known the horizontal surface of the parallelopiped can be drawn and the angle between the Ramnefjäll pegmatites and the master dykes can be calculated to $3^{\circ}$.

Actual observations show that the Ramnefjäll pegmatites are subparallel to the sandwich layer on horizontal surfaces (see Fig. 33), with an angle deviation certainly being less than $5^{\circ}$.

The original angle between the sandwich layers and the Ramnefjäll pegmatites can be constructed by substraction of the amount of stretching seen by the reduction of the distance between the master dykes from sector I to sector II. The calculations are of similar type to the calculations given above and the original angle between the sandwich layers and the Ramnefjäll pegmatites is calculated to $77^{\circ}$ (see Fig. 32A).

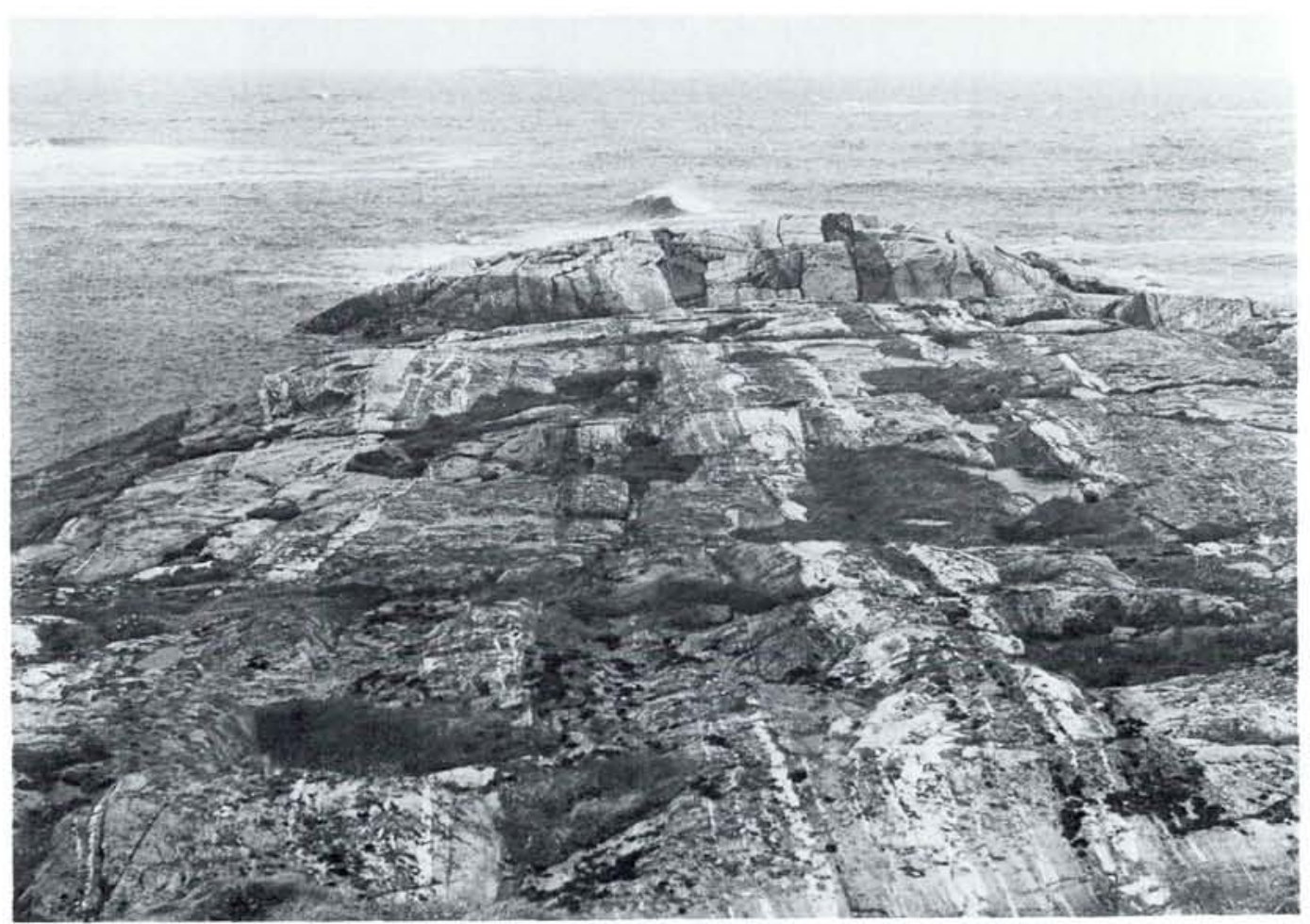

Fig. 33. View towards north on the Saltholmen (subsector IIIC), showing the parallelism between the Ramnefjäll pegmatites (white) and the gneiss and Koster dyke layers. 


\section{Competence relations during $D_{4 b}$}

To find out if there was any unobserved bulk competence contrast between the dyke and gneiss layers within the megalayer during $D_{4 b}$, the widths of the dyke layers were measured systematically in completely exposed sections parallel to $\mathrm{AA}^{\prime}$ and $\mathrm{BB}$ ' of Fig. 6. If such width measurements are to be of any value the gneiss layers along AA' and BB' should be of comparable materials. The host rock to the dykes in AA' consists essentially of the slightly gneissified Tjälleskär granite, while the host rock in the BB' section is the $D_{4}$-gneissified sheeted granite. Thus the pre- $D_{4}$ gneiss layers in both situations were massive granitic rocks, which can be expected to have comparable mechanical properties.

The measurements from the AA' traverse (p. 163) give the mean dyke thickness of $2.1 \mathrm{~m}$, or $2,2 \mathrm{~m}$ if dykes thinner than $0.1 \mathrm{~m}$ were omitted from the mean calculations. In the completely exposed sections parallel to BB' the thicknesses of all layers that could be recognised as dykes were measured, including dykes as little as $0.5 \mathrm{~cm}$ thick. In all 158 dykes thicknesses were recorded, these yielded a value for the mean thickness of $0.7 \mathrm{~m}$ with a standard deviation of 0.7 . The thickness variation is shown in Fig. 9.

If the rock mass was homogeneously deformed by pure constriction during the $\mathrm{D}_{4 \mathrm{~b}}$ stage, the expected mean thickness of the deformed dyke layers can be obtained from the mean thickness of the undeformed dykes and the factor of $D_{4^{-}}$ shortening normal to the strain $\mathrm{X}$ direction. This gives $0.3 \times 2.1 \mathrm{~m}=0.6 \mathrm{~m}$ as the expected mean for all deformed dykes, and $0.3 \times 2.2 \mathrm{~m}=0.7 \mathrm{~m}$ for all deformed dykes with an original thickness $>0.1 \mathrm{~m}$. Of these two mean values, the value obtained by omitting dykes thinner than $0.1 \mathrm{~m}$ is the most reasonable, as dykes with original thickness $<0.1 \mathrm{~m}$ could easily have become unrecognizable during deformation. Nevertheless the two predicted mean values are identical to the mean obtained from actual measurements.

The excellent fit between the predicted mean and the actual mean demonstrates, that the bulk $\mathrm{D}_{4 \mathrm{~b}}$ deformation was pure homogeneous constriction with no bulk competence contrast between the dykes and the gneiss layers. If the gneiss layers for example have had a larger bulk competence than the dyke layers, then the mean dyke thickness should have been smaller than the predicted mean (calculated on the basis of the mean shortening of every layer within the megalayer studied).

\section{Volume changes}

In the strain calculations the volume of the rock mass was regarded as constant, but if this was not so, the calculations could be seriously in error. Volume changes in a rock mass are due to phase changes and in a metamorphic environment are dependent on the conditions of metamorphism and on whether or not metasomatism has taken place. The volume changes may be studied by examination of the variations in density and chemistry. To arrive at a reliable result, 1) the original pre-deformation and pre-metamorphic state of the rocks must be known, 2) the deformed rocks must not have suffered post-kinematic recrystallisation, and 3) the initial chemical composition of the rocks must be well defined and should preferably show very little variation.

In the Koster sandwich the Koster dyke layers satisfy these demands and their density and chemistry have been investigated. The density has been measured on 26 samples of the fresh dolerites and 23 samples of amphibolites (Fig. 34). Both groups of samples show a normal distribution and the mean density of the dolerites is $\overline{\mathbf{D}}$

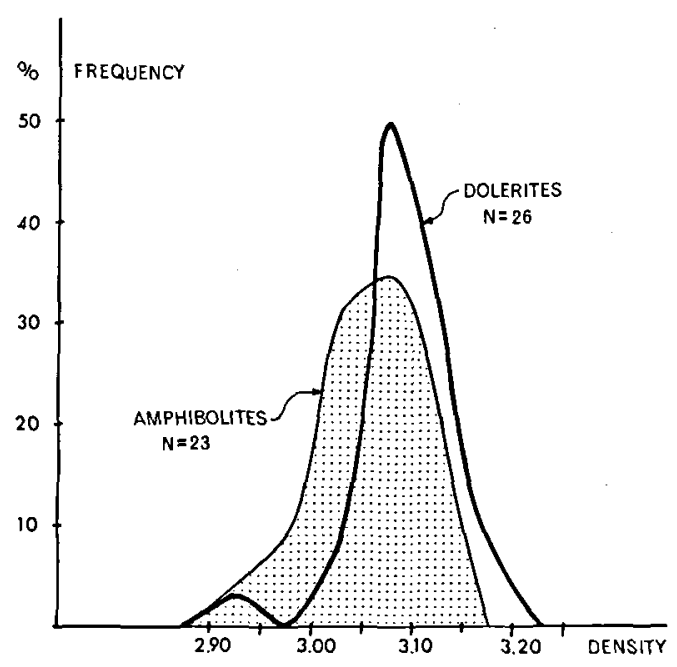

Fig. 34. Density variation in fresh and amphibolised Koster dykes. 


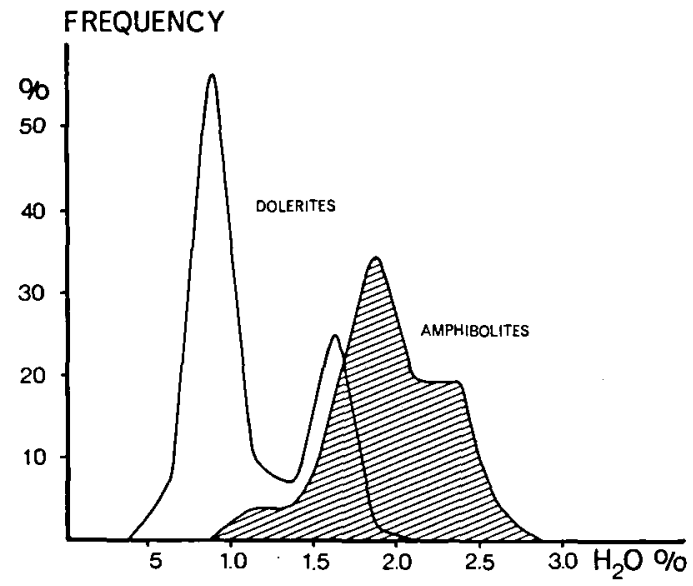

Fig. 35. $\mathrm{H}_{2} \mathrm{O}$ variation in fresh and amphibolised Koster dykes.

$=3.08 \pm 0.05$, while it is $\overline{\mathrm{D}}=3.05 \pm 0.05$ for the amphibolites. The difference is significant at the $3.75 \%$ level. That means that the volume has expanded $1 \%$ provided the recrystallisation is isochemical.

The Koster dyke swarm has been investigated geochemically (Hageskov, in prep.) and a large number of samples have been analysed for major elements and trace elements (Rb, Ba, Sr, La, Y, $\mathrm{Th}, \mathrm{Zr}, \mathrm{Nb}, \mathrm{Nb}, \mathrm{Ni}, \mathrm{Cr}$ ). Amphibolitised dykes from sector II and III have been compared to the fresh dykes of sector $I$, and it is seen that the most significant differences are an $\mathrm{H}_{2} \mathrm{O}$ enrichment of about $1 \%$ in the amphibolities (Fig. 35) and $\mathrm{Rb}$ enrichment and $\mathrm{Sr}$ depletion in thin $(<2$ $\mathrm{m})$ dykes of the high strain belt. Some of the thin dykes have also been enriched in $\left(\mathrm{K}_{2} \mathrm{O}\right)$ and depleted in $\left(\mathrm{CaO}, \mathrm{Na}_{2} \mathrm{O}, \mathrm{Ba}\right)$. The transformation of the igneous Koster dykes to amphibolites is then connected to a very restricted element exchange of which $\mathrm{H}_{2} \mathrm{O}$ accounts for a slight volume expansion.

From the investigations of both the density and the chemistry it is apparent that no important change in the volume of the basic layers has taken place during the deformation. The volume probably expanded $1 \%$ as a consequence of the transformation of the igneous paragenesis plagioclase $\left(A n_{70-35}\right)+$ clinopyroxene \pm olivine \pm orthopyroxene + biotite + titanomagnetite + ilmenite to the metamorphic paragenesis plagioclase $\left(\mathrm{An}_{35-25}\right)+$ hornblende + biotite + quartz + sphene \pm ilmenite. During this process $\mathrm{H}_{2} \mathrm{O}$ entered the rocks.

\section{Reconstruction of the regional pre- $\mathrm{D}_{4}$ structures of the archipelago}

The regional pre-dyking post $\mathrm{D}_{3}$ structures may be reconstructed from knowledge of the strain and the amount of rotation of the layered sandwich. The reconstructed pre- $\mathrm{D}_{4}$ map is shown in Fig. 11.

In the reconstruction the southern limb of the regional $D_{4}$ fold has been kept in a fixed position. The operations involved in the reconstruction of the pre- $\mathrm{D}_{4}$ map are shown in fig. 36. This figure shows three master dykes $(l, m, n)$, and a lithological boundary (b) in the gneiss which is cut by the master dykes at the points $x ", y$ " and $z "$. The line $q$ is normal to the undeformed master dykes, and is drawn at the boundary between undeformed and deformed dykes. The problem is to find the original position (y) of y". In Fig. 36B m is rotated clockwise until the dyke is straight and hereby y" is rotated to the position y'. As the multilayered sandwich was straight before the onset of $D_{4}$, the position of $Y^{\prime}$ will be in the correct plane, but the distance to $q$ will be too long because of the stretching. The stretching is expressed by the narrowing of the distance between $l$ and $n$. Finding the original position (y) of y' involves the same operation as that, which will make $l, m$ and $n$ parallel throughout their length. The amount of constrictional strain must be substracted to find the original position of $y$ and to parallelise $l, m$ and $n$, and that is a problem of volume calculations.

The way in which $y$ is found is illustrated in the sketch Fig. 36C, which is the most simple situation with horizontal stretching. In this figure $y^{\prime}$ is situated at the centre of the upper surface of a pyramid stump with height $h$. The ground surface of the pyramid stump is a square with an area $G$ $=\left(\sin 67^{\circ} \times Q\right)^{2}$, where $67^{\circ}$ is the dip of the undeformed sandwich (sector $I$ ) and $Q$ is the original distance between $l$ and $n$. The upper surface of the pyramid stump is also a square because deformation has been purely constrictional, and it has an area $\mathrm{g}=\left(\sin 75^{\circ} \times \mathrm{P}\right)^{2}$, where $75^{\circ}$ is the dip of the sandwich in sector III and P is the distance between $l$ and $n$ after deformation. The volume $\mathrm{Vp}$ can then be calculated from $\mathrm{Vp}=\mathrm{h} / 3(\mathrm{G}+\mathrm{g}$ $+\mathrm{Gg}$ ). The height $\mathrm{h}$ can be measured directly on 

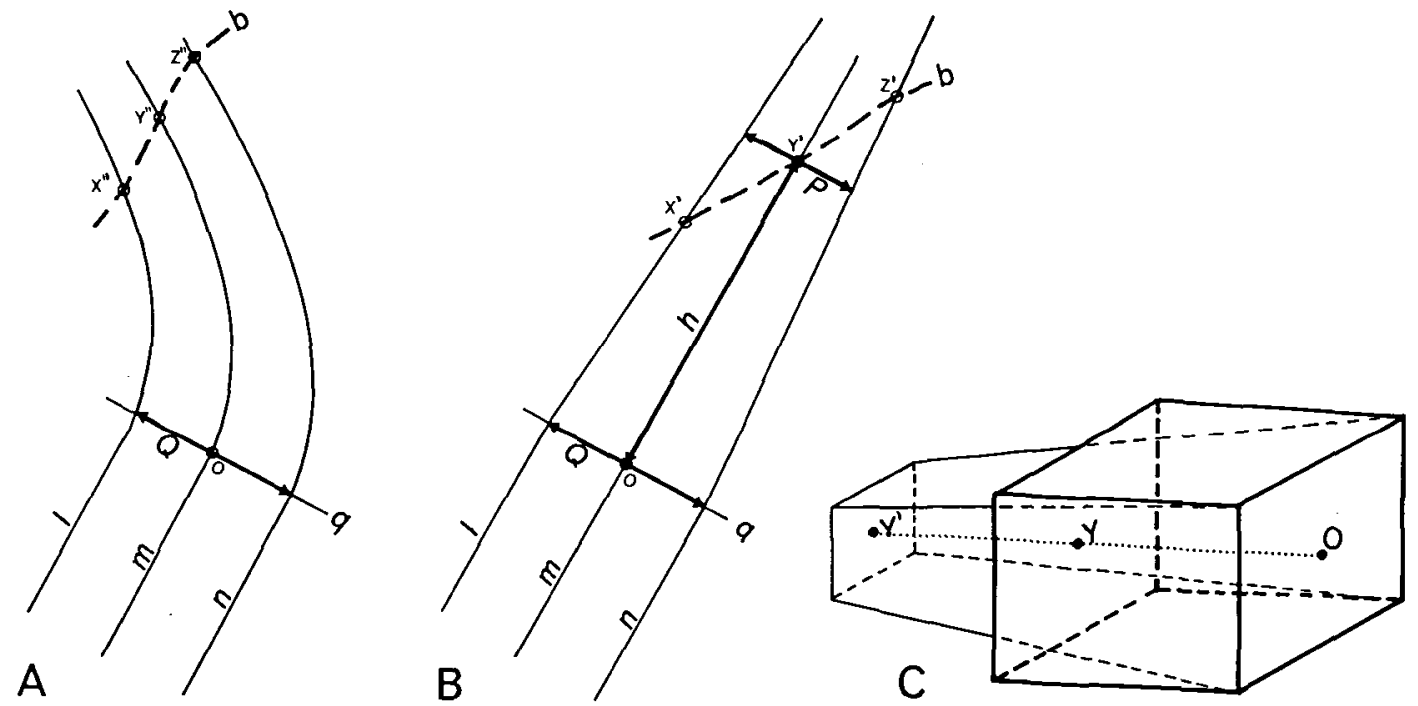

Fig. 36. The method of reconstruction of the pre- $\mathrm{D}_{4}$ structural pattern in the gneiss layers of the sandwich (see text for explanation).

the map as the distance oy" (Fig. 36A) as the stretching is horizontal.

The body deformed into the pyramid stump was originally a parallelopiped (Fig. 36C) with the volumes of $\mathrm{G} \times \mathrm{H}$, where $\mathrm{H}$ is unknown. Since the deformation has involved no significant change in volume, the volume of the parallelopiped is equal to the volume $\mathrm{Vp}$, and hence $\mathrm{H}$ can be calculated. When $\mathrm{H}$ is known the original position y of y' has been found, because it will be at a distance $\mathrm{H}$ from the ground surface.

The calculations can be done in the same way when the strain $\mathrm{X}$-axis has a plunge, but the measured $h$ value must be reduced to hos $\alpha$, where $\alpha$ is the plunge of the $\mathrm{X}$-axis.

The reconstruction of the pre-dyke structures (Fig. 11) was carried out at 1:10.000 in the way described above. The intersections between the lithological boundaries and the master dykes were rotated back until the master dykes are straight and then the $h$ distances were reduced. Finally the reconstructed positions of the intersections were joined. In the cases where the plunge of the stretching varies along a master dyke a mean plunge was used in the calculations.

The accuracy of the reconstructed map is restricted by possible flaws related to the construction of the master dyke map, neglect of the shear deformation related to the flexural slip mechanism, variations in the plunge of the stretching, and measurements of the distances between the master dykes.

When the reconstructed structural pattern of the archipelago is compared to the post- $\mathrm{D}_{4}$ pattern (Fig. 10), it is seen that the rotation and stretching in the northern limb of the Kyrkosund synform formed the major $D_{4}$ synform and antiform within sector III. These two $\mathrm{D}_{4}$ folds are both upright with NW-SE trending axial surfaces. By the comparison it is also seen, that only the southern boundary of the sheeted granite is known. That pre-dyke boundary follows in part the trend of the older structures, but it is discordant.

\section{Conclusions;}

\section{Modelling the $\mathrm{D}_{4}$ deformation}

In considering the $D_{4 a}$ and $D_{4 b}$ events the following four questions appear to be of a fundamental importance:

I Why did the multilayered sandwich in the high strain belt react in a homogeneous ductile manner during the main phase of stretching without any recognizable contrasts in competence?

II What factors controlled the localisation of the high strain belt? 
III What were the factors controlling the $\mathrm{D}_{4}$ recrystallisation?

IV What deformation mechanism caused the formation of the high strain belt and the constrictional strain?

I and II: The uniform ductile reaction of the sector III part of multilayered sandwich to the main phase of stretching $\left(D_{4 b}\right)$ was presumably caused by an interplay of softening processes, that were initiated during the late stages of $D_{4_{a}}$, when the rocks in sector III extensively recrystallised during the initial stretching under conditions of amphibolite facies metamorphism. In a mechanical sense softening can be expressed as a reduction in stress at a constant strain rate or as an increase in strain rate at constant stress (White et al. 1980). The different softening processes summarized below are reviewed and discussed by Cobbold (1977), White \& Knipe (1978), White et al. (1980), Brun \& Cobbold (1980) and Poirier (1980). The most important processes are geometrical softening, continuous recrystallisation, reaction softening, pore fluid effect and strain heating.

Geometrical softening occurs when the slip planes of the minerals rotate during the deformation to more favourable orientations, where the resolved shear stress is higher for a constant applied force. That means that the slip planes rotate towards parallelism with the flow plane, where the flow stresses for deformation by dislocation glide are at a minimum. The extent of the softening will depend on the initial fabric and its orientation relative to the flow plane and the flow direction.

Geometrical softening in a rock is followed by the softening effect of continuous recrystallisation, which continuously produces new strainfree, soft grains. The rate of formation of these soft grains at a given time will control how effective this softening will be.

Reaction softening and chemical softening cover softening processes related to metamorphism, metasomatism, phase transformation and diffusive reaction in the rocks. Enhanced ductility can be related to the rate of recrystallisation (presumably proportional to the strain rate) and the formation of softer minerals and smaller grains. Influx of water may dramatically enhance the ductility as 1) a small amount of lattice bound 'water' is known to weaken at least quartz, olivine and enstatite (Carter 1976, Post 1977, Ross $\&$ Nielsen 1978), 2) the presence of water favours metamorphic, metasomatic and diffusive reactions, and 3) the presence of a pore fluid may increase the ductility of silicate rocks as it does in calcite rocks (Rutter 1972).

Strain heating results from the conversion of mechanical energy into heat during the progress of deformation. It has been suggested that the amount of heat produced can raise the temperature to that required for partial melting (e.g. Nicolas et al. 1977), but even if temperature increases of this magnitude are unusual (Fleitout $\&$ Froidevaux 1980, Brun \& Cobbold 1980), increases of a few hundred degrees can be expected in major shear zones (Brun \& Cobbold 1980), where there are high differential stresses and the strain rate is high. Even a temperature increase of $100^{\circ}$ can lead to an order-of-magnitude increase in strain rate and hence is sufficient to localise $90 \%$ of the deformation in the hotter zone and may in certain circumstances cause a change in the deformation mechanism (Brun \& Cobbold 1980).

The layer-parallel shearing, which has affected the layers in the northern limb of the regional flexural-slip fold with increasing intensity to the north, has presumably initiated the recrystallisation and thereby started the softening processes. The most important softening processes during this stage of $D_{4}$ were presumably continuous recrystallisation and reaction softening accompanying an influx of water. Due to these processes the subsectors IIIB, C, D initially became a soft belt localised in the limb of the Kyrkosund fold and parallel to its axial surface.

When the progressive deformation reached the $D_{4 b}$ stage the initial soft belt had already been established. The further $D_{4 b}$ streching of the rock sandwich was localised in this belt, which reacted in a ductile and homogeneous manner. Thus the initial soft belt became the high strain belt. At the onset of $D_{4 b}$ geometrical softening and perhaps also strain heating joined in the softening processes. The geometrical softening was presumably caused by changes in the plunge of the stretching direction.

The change to ductile behaviour of the rock mass in the initial soft belt is believed to have been followed by a sudden and rapid increase in 
the strain by a sudden and rapid increase in the strain rate, when at a constant stress a threshold value in ductility was exceeded. Attainment of this threshold value could have triggered the onset of $D_{4 b}$. The further progress of the deformation decreased the stresses and late in $D_{4 b}$, when the competence contrasts between the layers were reestablished, the strain rate must also have decreased. If the high stress situation resulted in a very fast strain rate, strain heating could have raised the temperature (Brun \& Cobbold 1980) and added a softening effect. The softening effects are expected to have been most active early in $D_{4 b}$, when a rapid increase in the strain rate took place. This suggestion is based on the assumption that the effect of geometric softening decreases with increasing adjustment of the grains to the geometry of the deformation, that the chemical reactions are the most important until stable metamorphic parageneses are developed in the rocks, that the amount of free water may be decreased by formation of hydrous minerals, and that strain heating decreases with decreasing stress and strain rate (Brun \& Cobbold 1980).

III: The main $\mathrm{D}_{4}$ recrystallisation took place under conditions of amphibolite facies metamorphism; the exact PT conditions are unknown, but are expected to be of middle to lower amphibolite facies because no new leucosome appears to have developed in the granitic rocks. The temperature could have been $550-600^{\circ} \mathrm{C}$. The amphibolitisation of the dykes was accompanied by an influx of water.

The pattern and the amount of recrystallisation in the dykes coincide with the $\mathrm{D}_{4}$ strain pattern of the area (see Fig. 3). This coincidence is to be expected as deformation will have had an important influence on the initiation of the metamorphic reactions by straining the grains and opening of microcracks, whereby fluids more easily can enter and flow in the rocks. The lack of recrystallisation of sector $I$ is presumably due to the internal strain being insufficient to initiate recrystallisation.

An interesting question is wether during $D_{4}$ there existed a significant thermal gradient in the Koster area. Such a gradient could have been produced by strain heating being confined to the high strain zone, in which a fast strain rate under high stress could have raised the temperature in sector III to as high as the $550-600^{\circ}$ estimated for the metamorphism. It is hoped that work in progress will answer this question.

IV: The pattern of the $D_{4}$ deformation in the multilayered sandwich is believed to have resulted from deformation in a vertical NW-SEtrending shear zone, the NE side of which is unexposed. The SW side (Fig. 12) is vertical and parallel to the axial surface of the Kyrkosund synform and to the border og the high strain belt. The deformation within the shear zone had presumably a considerable component of heterogeneous sinistral shear, that acted horizontally parallel to the side of the shear zone, as the sandwich layers underwent an increasing amount of anticlockwise rotation and horizontal stretching $\left(D_{4 b}\right)$ with increasing distance from the margin of the shear zone. The $\geqq 3 \mathrm{~km}$ wide high strain belt of the shear zone is presumably situated in the central of the shear zone, because it is here that the greatest strain in ductile shear zones deformed by heterogeneous simple shear is located. The $\mathrm{D}_{4 \mathrm{~b}}$ homogeneous deformation related to the development of the high strain belt was initiated in the initial soft belt which was widened by the deformation (see model below).

Ductile shear zones are usually reported to have been formed by deformation having an important component of heterogeneous simple shear (Ramsay \& Graham 1970, Ramsay 1980). In such shear zones marker horizons become bent into sigmoidal folds, the shear zone limb of which rotates towards parallelism with the shear plane. The angle between the limb and the shear plane decreases with increasing strain. The shape of the strain ellipsoid in shear zones deformed by simple shear will be $X>Y=r>Z$, where $r$ is the radius of the unit sphere. When no volume change is involved in the strain, there will be no shortening or elongation of $Y$.

The stretching fabric and the prolate shape of the strain ellipsoid established for the high strain belt (p. 186) shows no direct evidence of simple shear strain, but this is not to be expected as strong pure constriction can only result from a composite deformation mechanism with or without volume change. To transform the simple shear ellipsoid to the prolate shape of the constriction ellipsoid the dimension of $Y$ has to be 

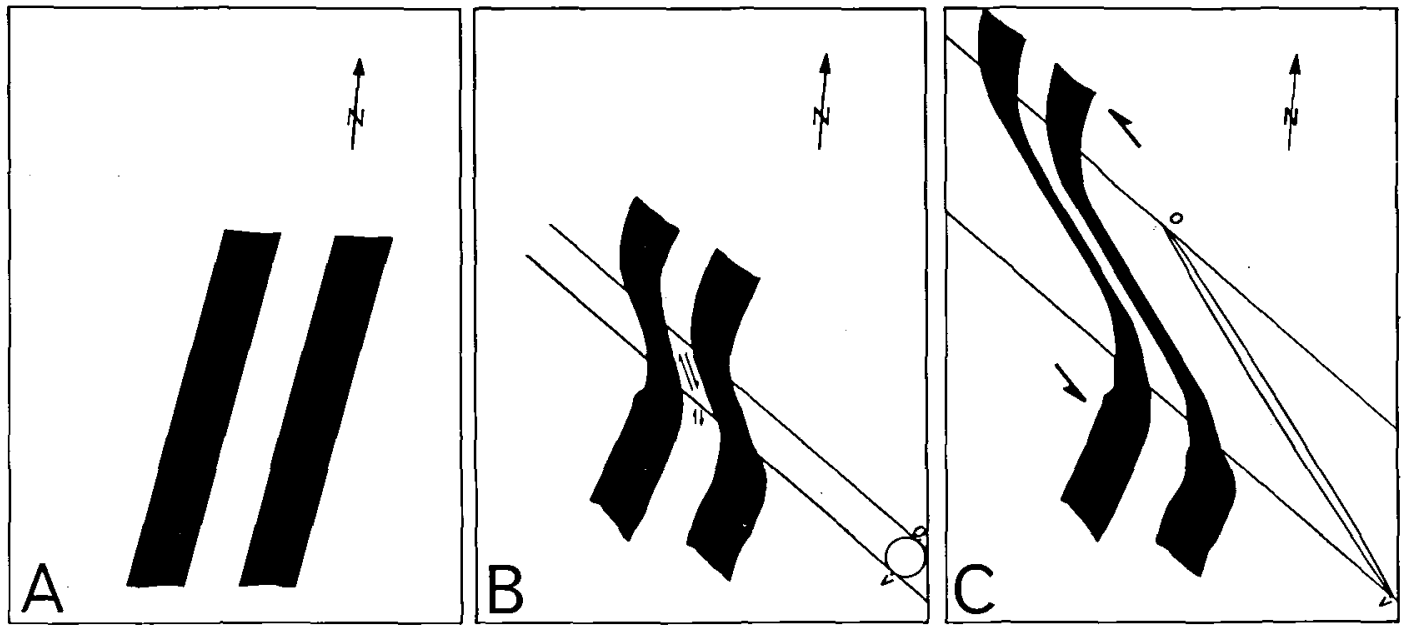

Fig. 37. The development of the high strain belt with constriction deformation. A: Undeformed state of the sandwich. B: Flexural slip folding with layer-parallel shearing; development of the initial soft belt. C: Opening of the soft belt by an overall shear couple forming an angle to the initial soft belt. This mechanism resulted in a component of sinistral simple shear and a component of pure shear with the $\mathrm{X}$ axis horizontal and normal to the margins of the initial soft belt.

reduced. A reduction in $Y$ can be achieved, if the deformation is followed by a volume reduction, but with large constriction strains unrealistic volume changes are necessary. Thus the shortening in $\mathrm{Y}$ must result from a composite deformation such as a combination of penecontemporaneous simple and pure shear. When pure shear interacts with simple shear a shortening in $\mathrm{Y}$ results, provided the pure shear has a component of shortening parallel to $Y$. The constriction strain of the Koster shear zone is explained by such a model.

The model for the evolution of the Koster shear zone is shown in Fig. 37A, B and C. In Fig. $37 \mathrm{~A}$ is shown the pre- $\mathrm{D}_{4}$ sandwich structure; this became involved in flexural-slip folding. Layerparallel shearing in the limb of the fold triggered the development of the initial soft belt (Fig. 37 B). Homogeneous simple shear - pure shear deformation $\left(D_{4 b}\right)$ became localised in the initial soft belt. Simple shear acted horizontally and sinistrally parallel to the initial soft belt, while pure shear resulted in horizontal widening and vertical thinning of the soft belt (Fig. $37 \mathrm{C}$ ).

The simple shear component of the composite deformation produced an ellipsoid with a vertical $Y_{s}$ axis and a horizontal $X_{s}$ axis oblique to the side of the initial soft belt. The pure shear component is considered to have had a horizontal component of extension $\left(X_{p}\right.$ axis) normal to the side of the initial soft belt and a vertical component of short- ening $\left(Z_{p}\right)$. The simple shear strain ellipsoid has thus the axes $X_{s}>Y_{s}>Z_{s}$, while the ellipsoid of the pure shear has the axes $X_{p}>Y_{p}>Z_{p}$. The axes of the finite ellipsoid are known from the strain calculations (p. 186) to be $X_{f}=7.07, Y_{f}=$ $0.18=Z_{\mathrm{f}}$. The horizontal axes of the three strain ellipsoids and the $\mathrm{X}_{\mathrm{f}} \mathrm{Z}_{\mathrm{f}}$ section of the finite ellipsoid are shown in Fig. 38. $Y_{f}=Z_{f}$ will be equal to $Z_{p}$, because the simple shear strain produced no shortening in the vertical direction.

To find the simple shear and pure shear strains that interacted to form the finite ellipsoid of the high strain belt, it is necessary to know the angle $\beta$ between the stretching direction $\left(X_{f}\right)$ and the side of the high strain belt. This angle can be measured directly to be about $16^{\circ}$. Knowing this angle and the finite strain axes, and given that $Y_{f}$ $=Z_{p}$ and that deformation took place without change in volume, the pure shear and simple shear ellipsoids can be found by iterative computer analysis. The dimensions found for the ellipsoid axes are: pure shear ellipsoid $-X_{p}=2.10$, $\mathrm{Y}_{\mathrm{p}}=0.62, \mathrm{Z}_{\mathrm{p}}=0.18$; simple shear ellipsoid $-\mathrm{X}_{\mathrm{s}}$ $=6.78, Y_{s}=0.62, Z_{s}=0.06$. The simple shear strain $\gamma$ is 10.9 , corresponding to an angular shear $\psi=84.7^{\circ}$.

The strain calculations mean that deformation in the high strain belt resulted in a horizontal sinistral displacement of not less than $33 \mathrm{~km}$, and that the initial soft belt increased 3.38 times in 


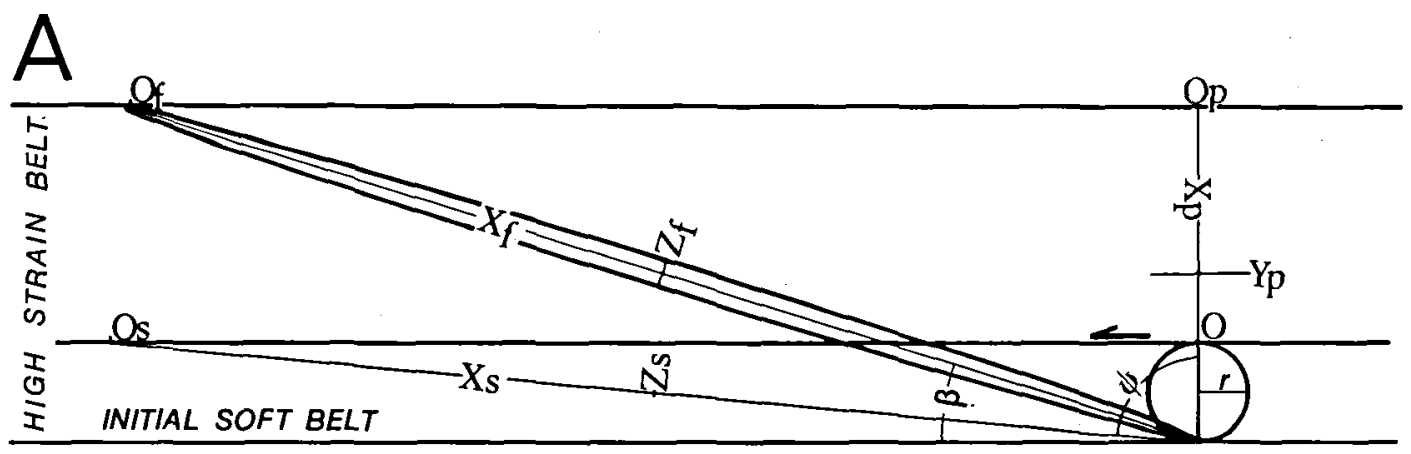

Fig. 38. Geometrical relations in the calculations of the strains, see the text for explanation.

width. If the high strain belt is wider than the known minimum of $3 \mathrm{~km}$, then the horizontal displacement must be increased by $\mathrm{D} \tan 84.7^{\circ}$, where $D$ is the width of the high strain belt. When the total deformation within the ductile shear zone is taken into consideration, about 2 $\mathrm{km}$ of sinistral displacement arising from the marginal areas of lower strain has to be added to the displacement in the high strain zone. Thus the total sinistral displacement is $\geqq 35 \mathrm{~km}$.

The model can explain constriction fabrics in ductile shear zones, where there is a substantial amount of simple shear and no reduction of the rock volume. Constriction deformations appear however to be very rare in ductile shear zones and the author does not know of any other example of almost pure constriction in the highly strained parts of ductile shears zones. Usually the ductile shear zones have L-S fabrics reflecting the orientation of the strain ellipsoid (Ramsey \& Graham 1970), but heterogeneous simple shear alone is unlikely to be responsible for the deformation in ductile shear zones, which are more likely to develop by a mechanism incorporating shortening or elongation across the zone (Coward 1976).

The oblique widening of the initial soft belt is presumably due to the initial soft belt having been developed at an angle to the overall major shear couple (Fig. 39 B). If the initial soft belt developed parallel to the overall shear couple, no change in width of the belt would have taken place (Fig. 39 A), while Fig. $39 \mathrm{C}$ shows how an overall shear couple at an angle to the initial soft
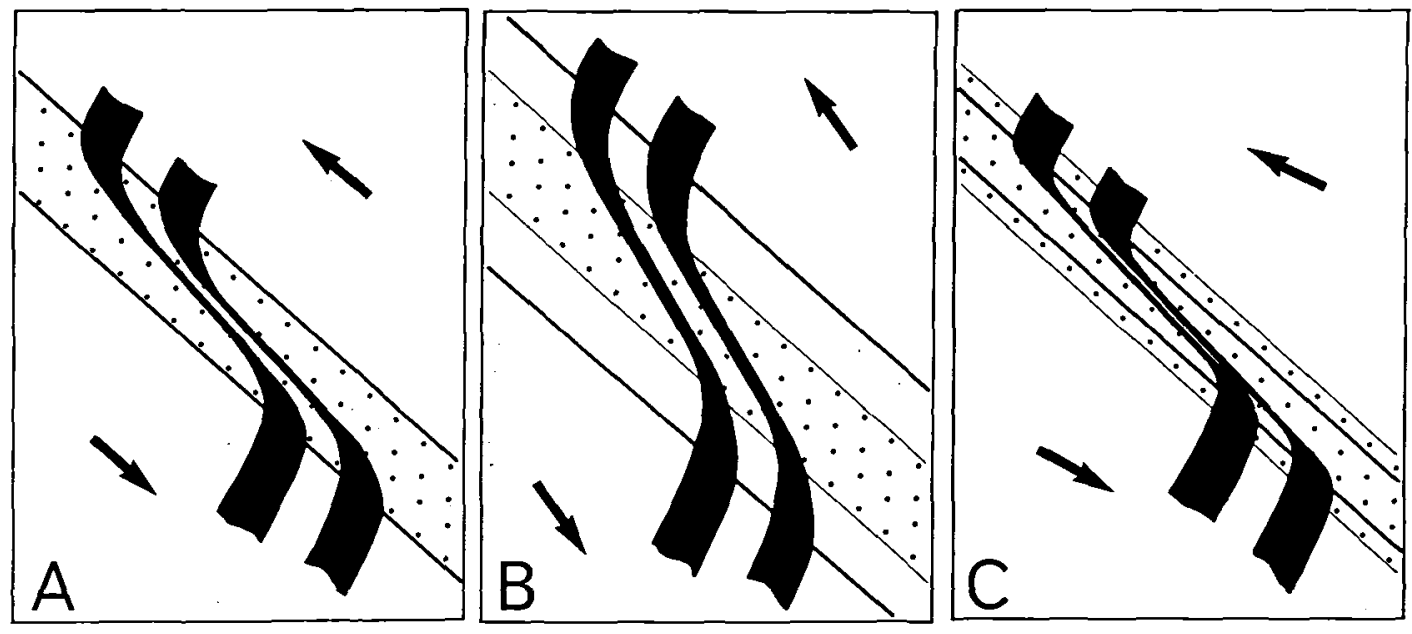

Fig. 39. Model relations between an initial soft belt developed: A) parallel to an overall shear couple. B and C) at an angle to an overall shear couple. Situation A results in a shear zone deformed by simple shear, B results in an expanding shear zone with simple shear - pure shear deformation, while $\mathrm{C}$ results in shortening across the shear zone and a simple shear - pure shear deformation. 
belt can lead to shortening across the belt. Thus, it can be seen, that the angle between the initial soft belt and the overall major shear couple has an important influence on the nature of the deformation that subsequently takes place in the shear zone. Deformational situations, where transcurrent movements of the host rocks of a shear zone have been followed by widening (Fig. 39 B) or shortening (Fig. $39 \mathrm{C}$ ), have been termed transtension and transpression respectively (Harland 1971, Sanderson \& Marchini 1984).

Acknowledgements. The author wishes to thank T. C. R. Pulvertaft for improving the English manuscript and C. Mohr for making the computer analysis of the composite deformation. $\mathrm{L}$. Stemmerik, C. Møller Frederiksen and J. Toft assisted during the field work. Thanks are also given to L. Samuelsson (S. G. U.) for his helpfulness and interest in the investigations. The project was financially supported by the Danish Natural Science Research Council.

\section{Dansk sammendrag}

Koster gangsværmen er en intens prakambrisk gangsværm, der blev dannet for 1015-1225 mill, år siden. Gangsværmen ses i Koster skærgården ud for Strömstad i Vestsverige, men der er blot en del af Kattsund-Koster gangsvarmzonen, som kan følges fra den centrale del af Oslofjorden og ned langs Bohuslän kysten mod Göteborg. Kattsund-Koster gangsværmzonens oprindelige doleritiske gange blev for ca. 1015 mill. år siden udsat for en så kraftig sveconorwegisk deformation og amfibolit facies metamorfose, at gangbjergarterne totalt omkrystalliserede til amfiboliter. Den sydlige del af Koster skærgården rummer dog en undtagelse fra dette, idet man her finder helt friske olivin førende tholeiiter. Følges de stejle NNE-SSW forløbende Koster-gange fra syd mod nord, ses det at gangene gradvist drejer mod nordvest. Samtidig med drejningen omkrystalliserer gangene og bliver først til delvis rekrystalliseret metadolerit og siden til linieret amfibolit. På baggrund af graden af deformation og omkrystallisation er skærgården opdelt i tre sektorer. Sektor I omfatter området med friske gange, sektor II området med metadoleriter og sektor III området med linierede amfiboliter.

Årsagen til den gradvise forøgelse $\mathrm{i}$ såvel deformation som omkrystallisation er, at de oprindelige $\mathrm{N}-\mathrm{S}$ forløbende gange bliver involveret $i$ en blød shearzone forløbende NW-SE $i$ den NØ-lige del af skærgården. Shearzonens SV grænse markeres af den begyndende bøjning af gangene. Shearzonens $N \emptyset$-lige granse er ikke blottet. Mekanisk set er bjergartsmassen i Koster skargården at opfatte som en 'multilayered sandwich' bestående af vekslende lag af gneiss og gangbjergart. Deformationen af denne sandwich resulterede i dannelsen af en større fold "Kyrkosund synform", der har en lodret NV-S $\emptyset$ strygende aksialflade og en foldeakse 303/66. Kyrkosund synformen blev dannet ved flexural slip folding med lagparallel glidning lokaliseret til inkompetente dyke lag.

Pả tværs af Kyrkosund synformens nordlige flanke udviklede der sig på grund af lagparallel shearing og rekrystallisation et balteformet område (the initial soft belt), hvortil den fortsatte deformation blev knyttet. I det fremadskridende deformationsforløb skelnes der mellem fire deformationstrin $\left(D_{4 a}, D_{4 b}, D_{4 c}\right.$ $\operatorname{og} D_{4 d}$ ). Til $D_{4 a}$ trinet hører dannelsen af Kyrkosund synformen $o g$ anlæggelsen af det initiale soft belt. Under $D_{4 b}$ indtraf der en kraftig horisontal strækning af det initiale soft belt. Denne strækning efterfulgtes af "tog" af assymmetriske folder $\left(D_{4 c}\right.$ og $\mathrm{D}_{4 \mathrm{~d}}$ ).

Den kraftige $\mathrm{D}_{4 \mathrm{~b}}$ strækning resulterede $\mathrm{i}$ en konstriktion deformation med strain ellipsoide akserne $\mathrm{X}=7.07, \mathrm{Y}=\mathrm{Z}=$ 0.18 . Strækningen foregik $i$ en blød og mekanisk ensartet bjergartsmasse, hvor der ikke eksisterede kompetence kontrast mellem gnejs- og gangslagene. $D_{4 b}$ deformationen og den ledsagende metamorfose resulterede $i$ en negligibel forøgelse af gangenes volumen på $1 \%$. Den resulterende konstriktion deformation anses for at være resultatet af en sammensat simple shearpure shear deformationsmekanisme. Simple shear deformationen var sinistral og horisontal med bevægelsesretningen parallel med det initiale soft belts sider. Denne deformation er beregnet til at have et simple shear strain $\gamma=10.9$ svarende til et angular shear på $84.7^{\circ}$ Ved pure shear deformation blev det initiale soft belt gjort bredere samtidig med at bjergartsmassen blev udtyndet i vertikal retning. Bredden af det initiale soft belt blev derved forøges til 3.4 gange den oprindelige bredde. Ialt resulterede shearzonens deformation $\mathbf{i}$ en horisontal sinistral forskydning på mindst $35 \mathrm{~km}$.

\section{References}

Asklund, B. 1950: Kosteröerna, ett nyckelområde för Västre Sveriges Precambriske geologi. Sver. Geol. Unders. Ser. C, $517,56 \mathrm{pp}$.

Berthelsen, A. 1978: Himalayan and Sveconorwegian tectonics - a comparison. In: Saklani, P. S. (ed) 1978: Tectonic geology of the Himalayas, 287-294.

Berthelsen, A. 1980: Towards a palinspastic tectonic analysis of the Baltic Shield. Intern. Geol. Congr., Paris 1980, colloquium C. 6.

Biot, M. A. 1961: Theory of folding of stratified viscoelastic media and its implications in tectonics and orogenesis. Bull. geol. Soc. Am. 72, 1595-1620.

Brun, J. P. \& Cobbold, P. R. 1980: Strain heating and thermal softening in continental shear zones: a review. J. Struct. Geol. 1, No. 1/2, 149-158.

Carter, N. L. 1976: Steady state flow of rocks. Rev. Geophys. \& Space phys. 14, 301-360.

Cobbold, P. R. 1977: Description and origin of banded deformation structures. Can. J. Earth Sci. 14, 2510-2523.

Coward, M. P. 1976: Strain within ductile shear zones. Tectonophysics 34, 181-197.

Daly, J. S., Park, R. G. \& Cliff, R. A. 1979: Rb-Sr ages of intrusive plutonic rocks from the Stora Le Marstrand belt i Orust, SW Sweden. Prec. Res. 9, 189-198.

Daly, J. S., Park, T. G. \& Cliff, R. A. 1983: Rb-Sr isotopic equilibrium during Sveconorwegian (=Grenville) deformation and metamorphism of the Orust dykes, SW Sweden. Lithos 16, 307-318.

Daly, J. S., Park, R. G. \& Crane, A. 1982: Age relations of Sveconorwegian granitoids rocks in the Stora Le Marstrand belt, Orust area, Sweden. Geol. Fören. Stockh. Förh. 104, 11-16.

DeGeer, G. 1899: Om Algonkisk veckning i Fennoskandias gränsområde. Geol. Fören. Stockh. Förh. 21, 675-693.

DeGeer, G. 1902: Beskriftning till kartbladet Strömstad med Koster. Sver. Geol. Unders. Ser. AC, 1.

Falkum, T. \& Petersen, J. S. 1980: The Sveconorwegian orogenic belt, a case of late Proterozoic plate collision. Geol. Rundsch. 69, 622-647. 
Fleitout, L. \& Froidevaux, C. 1980: Thermal and mechanical evolution of shear zones. J. Struc. Geol. 2, No. 1/2, 159 164.

Fleuty, M. J. 1964: The description of folds. Proc. Geol. Ass. $75,461-492$.

Flinn, D. 1962: On folding during three-dimensional progressive deformation. $Q$. Jl. geol. Soc. Lond., 118, 385-433.

Flinn, D. 1965: On the symmetry principle and the deformation ellipsoid. Geol. Mag. 102, 36-45.

Gavelin, A. 1914: Yttrandande med anledning af H. E. Johansson föredrag om svenska kvarts- og feldspatförekomster. Geol. Fören. Stockh. Förh. 36, 127.

Geijer, P. 1963: The Precambrian of Sweden: In: Rankama, K.: The Precambrian, 1, 81-143. Interscience Publishers. New York - London - Sydney.

Hageskov, B. 1978: On the Precambrian structures of the Sandbukta-Mølen inlier in the Oslo graben, SE Norway Norsk geol. Tidsskr. 58, 69-80.

Hageskov, B. 1980: The Sveconorwegian structures of the Norwegian part of the Kongsberg-Bamble- $\varnothing$ stfold segment. Geol. Fören. Stockh. Förh. 102, 150-155.

Hageskov, B. 1984: Magnetic suscpetibility used in mapping of amphibolite facies recrystallisation in basic dykes. Tectoniphysics 108, 339-351.

Hageskov, B. \& Pedersen, S. 1981: Rb/Sr whole rock age determinations from the western part of the $\emptyset$ stfold basement complex, SE Norway. Bull. geol. Soc. Denmark, vol. $29,119-128$.

Harland, W. B. 1971: Tectonic transpression in Caledonian Spitsbergen, Geol. Mag. 108, 27-41.

Hills, E. S. 1963: Elements of structural geology. Methuen \& Co. Ltd. 483 pp.

Larsson, W. 1956: Beskrivning til kartbladet Vårvik. Berggrunden. Sver. Geol. Unders. Ser. A, 187, 10-127.

Lundegårdh, P. H. 1958: Göteborgstraktens berggrund. Sver. Geol. Unders. Ser. C, 553.

Lundegårdh, P. H., Lundquist, J. \& Lindström, M. 1964: Berg och jord $i$ Sverige. Almquist \& Wiksell, 348 pp.

Lundqvist, T. 1979: The Precambrian of Sweden. Sver. Geol. Unders. Ser. C, 768, 87 pp.

Magnusson, N. H. 1963: Sveriges Geologi. In: Magnusson, N. H., Lundqvist, G. \& Regnéll, G. 698 pp., 4th Edition, Scandinavian University Books, Svenska Bokförlaget/Norsteds.

Morthorst, J. R., Zeck, H. P. \& Lundegårdh, P. H. 1983: The Proterozoic hyperites in southern Värmland, western Sweden. Sver. Geol. Unders. Ser. Ba 30, 104 pp.

Nicolas, A., Bonchez, J. L., Blaise, J. \& Poirier, J. P. 1977: Geological aspects of deformation in continental shear zones. Tectonophysics 42, 55-73.

Park, R. G., Bailey, A., Crane, A., Creswell, P. \& Standley, R. 1979: Structure and geological history of the Stora Le marstrand rocks in western Orust, Southwestern Sweden. Sver. Geol. Unders. Ser. C, nr. 763, 1-36.

Pedersen, S., Berthelsen, A., Falkum, T., Graversen, O., Hageskov, B., Maaløe, S., Petersen, J. S., Skjernaa, L. \&
Wilson, J. R. 1978: Rb/Sr-dating of the plutonic and tectonic evolution of the Sveconorwegian Province, Southern Norway. ICOG Denver, U. S. Geol. Surv. Open-File rep. 78, 701, 329-331.

Poirier, J. P. 1980: Shear zone localization and shear instability in materials in the ductile field. J. Struc. Geol. 1, No. 1/2, 135-142.

Post, R. L. 1977: High temperature creep of Mt. Burnel dunite. Tectonophysics 42, 75-110.

Ramberg, H. 1955: Natural and experimental boudinage and pinch-and-swell structures. J. Geol. 53, 512-526.

Ramberg, H. 1959: Evolution of ptygmatic folding. Norsk Geol. Tidsskr. 39, 99-151.

Ramsay, J. G. 1967: Folding and fracturing of rocks. McGraw Hill, 568 pp.

Ramsay, J. G. 1980: Shear zone geometry: a review. J. Struct. Geol. 2, No. 1/2, 83-99.

Ramsay, J. G. \& Graham, R. H. 1970: Strain variation in shear belts. Can. J. Earth Sci. 7, 786-813.

Ross, J. V. \& Nielsen, K. C. 1978: High temperature flow of wet polycrystalline enstatite. Tectonophysics 44, 233-261.

Rutter, E. H. 1972: The influence of interstitial water on the rheological behaviour of calcite rocks. Tectonophysics 14, 13-33.

Samuelsson, L. 1980: Major features of the Proterozoic of the Götebrog region, Sweden. Geol. Fören. Stockh. Förh. 102, 141-144.

Samuelsson, L. \& Åhäll, K. I. 1984: Modell av den proterozoiska utvekling i Stora Le Marstrand formations område i västra Bohus län. Medd. Stockh. Univ. Geol. Inst. 225, 191.

Sanderson, D. J. \& Marchini, W. R. D. 1984: Transpression. J. Struct. Geol. 6, 449-458.

Skiöld, T. 1976: The interpretation of the Rb-Sr and K-Ar ages of late Precambrian rocks in south-western Sweden. Geol. Fören. Stockh. Förh. 98, 3-28.

Starmer, I. C. 1972: The Sveconorwegian regeneration and earlier orogenic events in the Bamble Series, south Norway, Nor. Geol. Unders. 277, 37-52.

Starmer, I. C. 1977: The geology and evolution of the southwestern part of the Kongsberg series. Norsk Geol. Tidsskr. $57,1-22$.

Turner, F. J. \& Weiss, L. E. 1963: Structural analysis of metamorphic tectonites. McGraw-Hill Book Co. New York, 545 $\mathrm{pp}$.

Welin, E. \& Gorbatschev, R. 1978: Rb-Sr isotopic relations of a tonalitic instrusion on Tjorn Island, south-western Sweden. Geol. Fören. Stockh. Förh. 100, 101-102.

White, S. H. \& Knipe, R. J. 1978: Transformation - and reaction enhanced ductility in rocks. J. Geol. Soc. Lond. $135,513-516$.

White, S. H., Burrows, S. E., Carreras, J., Shaw, N. D. \& Humphreys, F. J. 1980: On mylonites in ductile shear zones. J. Struct. Geol. 2, No. 1/2, 175-187.

Whitten, E. H. T. 1966: Structural geology of folded rocks. Rand McNally \& Co., Chicago, 663 pp. 